\title{
Expedition 308 summary ${ }^{1}$
}

\author{
Expedition 308 Scientists $^{2}$
}

\section{Chapter contents}

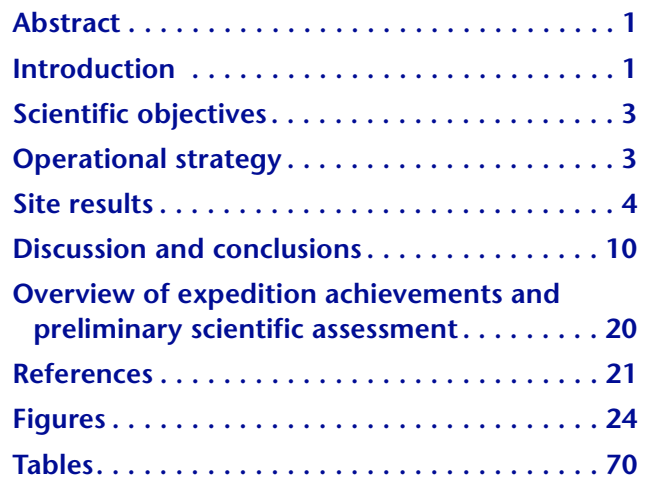

${ }^{1}$ Expedition 308 Scientists, 2006. Expedition 308 summary. In Flemings, P.B., Behrmann, J.H., John, C.M., and the Expedition 308 Scientists, Proc. IODP, 308: College Station TX (Integrated Ocean Drilling Program Management International, Inc.). doi:10.2204/iodp.proc.308.101.2006 ${ }^{2}$ Expedition 308 Scientists' addresses.

\begin{abstract}
Integrated Ocean Drilling Program (IODP) Expedition 308 is the first stage of a two-component program dedicated to the study of overpressure and fluid flow on the Gulf of Mexico continental slope. Drilling at six sites revealed an active hydrodynamic environment and provided insight into geological processes near the seafloor. We tested a multidimensional flow model by examining how physical properties, pressure, temperature, and pore fluid composition vary within low-permeability mudstones that overlie a permeable and overpressured aquifer. We drilled, logged, and made in situ pressure and temperature measurements in BrazosTrinity Basin IV off the Texas Gulf Coast where low sedimentation rates and normal pressures were predicted. We contrasted these observations with experiments in the Ursa region off the Mississippi Delta where rapid Pleistocene sedimentation occurred. At Ursa, multiple pore pressure penetrometer measurements recorded values that lie halfway between the hydrostatic pressure and the lithostatic pressure. Porosity-depth profiles suggest that these overpressures are maintained by compaction disequilibrium. Log, core, and seismic data illustrate that this overpressured region was subject to multiple events of slope instability, which generated mass transport deposits. A surprising result is that mudstones beneath Brazos-Trinity Basin IV are undercompacted, and most likely overpressured, relative to mudstones at the basin margin. Interbedded sands and mudstones within Brazos-Trinity Basin IV record a fascinating stratigraphic history that relates turbidite formation to eustatic sea level change. Postcruise science on both areas investigated will combine theoretical modeling and laboratory analysis to further illuminate coupled processes of flow, sedimentation, and deformation on passive continental margins.
\end{abstract}

\section{Introduction}

Rapid sediment loading ( $>1 \mathrm{~mm} / \mathrm{y})$ drives overpressure $\left(P^{\star}\right.$; pressure in excess of hydrostatic) in basins around the world (Rubey and Hubbert, 1959; Fertl, 1976). Sedimentation is so rapid that fluids cannot escape, the fluids bear some of the overlying sediment load, and pore pressures become greater than hydrostatic (Fig. F1). 
Recent work has focused on how sedimentation and common stratigraphic architectures couple to produce two- and three-dimensional flow fields. For example, if a permeable sand is rapidly buried by lowpermeability mud of laterally varying thickness, fluids flow laterally along the sand to regions of low overburden before they are expelled into the overlying sediment (Fig. F2A). This creates characteristic distributions of rock properties, fluid pressure, effective stress, temperature, and fluid chemistry in the aquifers and bounding mud (Fig. F2B). This flowfocusing process can cause slope instability near the seafloor (Fig. F3A) (Dugan and Flemings, 2000; Flemings et al., 2002); in the deeper subsurface, this process can drive fluids through low-permeability strata to ultimately vent them at the seafloor (Fig. F3B) (Boehm and Moore, 2002; Davies et al., 2002; Seldon and Flemings, 2005).

Expedition 308 documented the spatial variation in pressure, vertical stress, and rock properties in a flow-focusing environment. We first established rock and fluid properties along a transect at a reference location (Brazos-Trinity Basin IV). We then drilled multiple holes along a transect in the overpressured Ursa region to characterize spatial variation in rock properties, temperature, pressure, and chemistry.

\section{Geological overview: Gulf of Mexico}

Sedimentation, deformation, hydrodynamics, slope stability, and biological communities are interwoven in the Pleistocene strata of the Gulf of Mexico (Fig. F4). Rapid sedimentation upon a mobile salt substrate is the driving force behind many of the active processes present (Worrall and Snelson, 1989). Bryant et al. (1990) described the physiographic and bathymetric characteristics of this continental slope (Fig. F4). In the region offshore Texas and western Louisiana, individual slope basins are surrounded by elevated salt highs (Pratson and Ryan, 1994), producing a remarkable hummocky topography. This morphology is obscured in the eastern Gulf of Mexico downslope of the present Mississippi River, where sedimentation was focused during the Quaternary, whereas the region offshore Texas and Louisiana was relatively starved of sediment during the same time period.

Late Pleistocene sediments were drilled in BrazosTrinity Basin IV and Ursa Basin (Fig. F4). The sedimentation rate in Brazos-Trinity Basin IV was relatively low, whereas the sedimentation rate in Ursa Basin was envisioned to reach rates of at least $1 \mathrm{~cm} / \mathrm{y}$. We anticipated hydrostatic pore fluid pressures in Brazos-Trinity Basin IV and overpressured pore fluids in Ursa Basin.

\section{Geological setting}

\section{Brazos-Trinity Basin IV}

Brazos-Trinity Basin IV is $200 \mathrm{~km}$ due south of Galveston, Texas (USA) in $\sim 1400 \mathrm{~m}$ of water (Figs. F4, F5). The basin is one of a chain of five basins that are separated by interbasinal highs. It is a classic area for analysis of turbidite depositional environments and it is used as a modern analog to describe the formation of deepwater turbidite deposits (Winker, 1996; Badalini et al., 2000; Winker and Booth, 2000).

The primary data set used to evaluate the well locations is a high-resolution two-dimensional (2-D) seismic survey acquired by Shell Exploration and Production Company to image the turbidite stratigraphy (Fig. F5). The line spacing is $\sim 300 \mathrm{~m}$. Dip seismic Line 3020 shows the three drilled locations (Fig. F6). A strike line through Site U1320 is also illustrated (Fig. F7). Site U1320 (Figs. F5, F6, F7) is located where the turbidite deposits are thickest, whereas Site U1319 (Figs. F5, F6) is on the southern flank of the basin where turbidite deposits are more condensed. Site U1321 was scheduled for loggingwhile-drilling/measurement-while-drilling (LWD/ MWD) activities only.

\section{Ursa Basin}

Ursa Basin ( $150 \mathrm{~km}$ southeast of New Orleans, Louisiana [USA]) lies in $\sim 1000 \mathrm{~m}$ of water (Figs. F4, F8). The region is of economic interest because of its prolific oilfields that lie at depths $>4000$ meters below seafloor (mbsf). The Ursa field is in Mississippi Canyon Blocks 855, 897, and 899 and is $11.9 \mathrm{~km}$ east of the Mars tension leg platform.

Six extraordinary three-dimensional (3-D) seismic data sets are available within Ursa Basin (Fig. F9). Shell and industry partners shot the Ursa 96 exploration survey for exploration purposes. The high-resolution surveys were shot by Shell for the purpose of shallow hazards analysis.

Winker and Booth (2000) described deposition of Quaternary sediments. The Blue Unit is a late Pleistocene, sand-dominated, "ponded fan" that was deposited in a broad topographic depression that extended in an east-west direction for as much as 200 $\mathrm{km}$ and a north-south direction for as much as 100 $\mathrm{km}$. The Blue Unit is overlain by a leveed-channel assemblage that is mud dominated and has dramatic along-strike variation in thickness. Pulham (1993) described a similar facies assemblage for this region.

Shell made downhole pressure measurements with a pore-pressure penetrometer (piezoprobe) at the Ursa platform (Eaton, 1999; Pelletier et al., 1999; Ostermeier et al., 2000, 2001) (Fig. F10). They also ac- 
quired whole-core samples and performed consolidation experiments to evaluate preconsolidation stress and estimate overpressure. Piezoprobe measurements (circles) and maximum past effective stresses interpreted from consolidation experiments (triangles) indicate that (1) overpressure begins near the seafloor and (2) the pore pressure is $\sim 50 \%$ of the way between hydrostatic $\left(P_{\mathrm{h}}\right)$ and lithostatic $\left(\sigma_{\mathrm{v}}\right)$ (Fig. F10). Pressures (both hydrostatic and lithostatic) are calculated from below seafloor and not from sea level.

Seismic Line A-A' (Fig. F11) illustrates the Ursa drill sites. The sedimentary section is composed of a 300 $\mathrm{m}$ thick overburden that is predominantly mudstone. Beneath the overburden lies the first significant sand of the Blue Unit. The Blue Unit has a relatively flat base. Its upper boundary has relief, which most likely reflects postdepositional erosion. The Blue Unit is composed of interbedded sand and mud (Figs. F10, F11). A levee-channel facies overlies the Blue Unit; it has a sand-cored channel that is flanked by mud-prone levee deposits. A mud package that thickens to the west overlies these deposits. This package contains numerous mass transport deposits (MTDs). The uppermost mud contains distal deposits of a larger levee-channel system, formed to the west, and hemipelagic drape.

\section{Scientific objectives}

The six scientific objectives of Expedition 308 are described below.

\section{Document how pressure, stress, and geology couple to control fluid migration on passive margins.}

We hypothesized that flow-focusing is present in Ursa Basin (Figs. F2, F3). This should result in a characteristic spatial distribution of fluid pressure and rock properties (e.g., consolidation, permeability, and shear strength) in the mud overlying the Blue Unit. Our objective was to measure fluid pressure and rock properties through downhole tools, core, and logs to establish the vertical and lateral variation in pressure and rock properties above the Blue Unit. These data would test and refine the flow-focusing model.

\section{Establish reference properties at Brazos- Trinity Basin IV sites.}

We wished to establish reference logging and core properties where overpressure is hypothesized to be zero and thus to measure properties at a range of effective stresses. These data would serve as a baseline against which the properties measured in Ursa Basin could be compared, allowing us to establish the deviation in sediment and fluid properties caused by fluid overpressure and low effective stress.

\section{Illuminate the controls on slope stability.}

Numerous mass transport deposits are present in Ursa Basin. We wished to determine pore pressure, rock properties, and overburden stress to predict the potential for mass transport deposits in the future and to estimate the conditions that drove previous mass transport deposits.

\section{Understand rates of sedimentation and timing of mass transport deposits.}

Sedimentation rate drives the generation of overpressure. However, the age of strata in Ursa Basin is poorly understood. We wished to establish an age model to estimate the sedimentation rate and the timing of MTDs.

\section{Establish geotechnical and petrophysical properties of shallow sediments.}

We wished to understand the state and evolution of geotechnical and petrophysical properties of mud at effective stresses encountered between the seafloor and 500 mbsf. A complete logging suite, in situ measurements of permeability and pressure, and core samples will allow us to understand compaction and flow processes near the seafloor.

\section{Provide an extraordinary data set to observe ponded and channelized turbidite systems.}

Brazos-Trinity Basin IV and Ursa Basin are foci of study for turbidite depositional systems. Logging and core data will provide a good opportunity to study turbidite depositional systems and related MTDs.

\section{Operational strategy}

The overall strategy for Expedition 308 was to complete continuous coring, wireline logging, in situ measurements, and LWD/MWD operations at each primary site. As time allowed, we would also visit alternate locations. To minimize the time that expensive LWD tools and personnel were kept on board the ship, we first cored and performed downhole measurements in Brazos-Trinity Basin IV and then performed LWD measurements first in Brazos-Trinity Basin IV and then in Ursa Basin. Thereafter, the LWD tools were offloaded and final coring and downhole measurements were performed in Ursa Basin (Table T2). 
We used LWD because we expected to encounter thick unconsolidated sands in Brazos-Trinity Basin IV and because we might encounter unconsolidated sands in Ursa Basin. Unconsolidated sands can create unstable boreholes where it is not possible to deploy wireline tools. LWD would ensure that a good logging suite would be obtained.

We also planned to use MWD. In MWD, logging data are communicated in real time from near the drill bit to the ship so that the borehole conditions can be continuously monitored. In Ursa Basin, we expected to encounter overpressured mud and it was possible we would encounter overpressured and unconsolidated sands. If we encountered overpressured and unconsolidated sands, there was a risk that "shallowwater flow" would occur. Shallow-water flow results when overpressured, unconsolidated sands flow into a borehole that has a lower pressure than the formation pressure. With MWD, we would be able to monitor both the downhole annular pressure and the formation lithology. When shallow-water flow occurs, a pressure peak is recorded as sand flows into the borehole. Through continuous monitoring we would be able to decide whether it was necessary to increase the mud weight to offset the flow into the borehole or terminate the drilling and kill the well.

Finally, to minimize shallow-water flow, we planned to use heavy mud during drilling and coring of portions of Sites U1324 and U1323. We also planned to deploy heavy mud during long-term in situ measurements with penetration probes (Davis-Villinger Temperature-Pressure Probe [DVTPP] or temperature/ dual pressure [T2P] probe).

It was planned to use two downhole tools to measure pressure and temperature: the T2P, which was designed by the Massachusetts Institute of Technology (MIT), Pennsylvania State University, and Integrated Ocean Drilling Program (IODP) U.S. Implementing Organization Science Services, Texas A\&M University (TAMU) and the DVTPP. The T2P is designed to measure pore pressure more rapidly than the DVTPP. It has a narrow tip with a temperature and pressure sensor; a second pressure measurement is collected slightly up-probe from the sensors at the tip (Fig. F12). The design allows for rapid measurement of pressure in low-permeability sediments. In addition to temperature measurements made with the T2P and DVTPP, temperature measurements were made during coring with the advanced piston corer (APC) using the APC temperature (APCT) tool. Sampling of multiple $10-20 \mathrm{~cm}$ long whole-round cores was planned to assist interpretation of the T2P and DVTPP data, directly measure formation pressures, and infer the in situ stress state through laboratory analysis.

\section{Site results}

\section{Site U1319}

Site U1319 is located on the southern flank of Brazos-Trinity Basin IV (Figs. F5, F6). The primary objective at this site was to establish a reference section of rock and fluid properties in a normally pressured basin. Secondary objectives included establishing an age model for Brazos-Trinity Basin IV and studying turbidite deposits. To achieve these objectives, Hole U1319A was continuously cored from the seafloor to a terminal depth (TD) of 157.5 mbsf. A MWD/LWDdedicated hole (Hole U1319B) was then drilled to a TD of 180 mbsf.

Site U1319 is located at the southern edge of the basin. As a result, the cored succession of hemipelagic deposits and turbidites (Fig. F13) is condensed relative to that at the basin center. Nevertheless, a detailed record of turbidite deposition was recovered, which could be correlated to the basin center. Six lithostratigraphic units were recognized:

- Unit I (Holocene drape),

- Unit II (turbidites and debris flows),

- Unit III (hemipelagic sediments),

- Unit IV (distal turbidites),

- Unit V (hemipelagic sediments), and

- Unit VI (very distal turbidites mixed with hemipelagic sediments).

Unit $\mathrm{V}$ was deposited prior to formation of the Brazos-Trinity Basin IV, and all overlying sediments were deposited within it. Ash Layer Y8, a regional stratigraphic marker resulting from the Los Chocoyos (Guatemala) eruption and dated at 84 ka (Drexler et al., 1980; Mallarino et al., in press), was recovered in Unit III. Hemipelagic Units I and V are interpreted to have been deposited during eustatic highstands at the present and at $125 \mathrm{ka}$, respectively. Rare to abundant assemblages of well-preserved microfossils, spanning the late Pleistocene-Holocene period (marine oxygen isotope Stages [MIS] 1-6), were recovered. Tropical to subtropical species dominate the interglacial assemblages, whereas cool-temperate species are more common in assemblages from glacial intervals. The absence of reworked Cretaceous-Neogene nannofossils in the lower part of Hole U1319A (Units III and V) point to quiet openmarine environments. Moderately abundant benthic foraminifers in the upper $\sim 30 \mathrm{~m}$ of the hole indicate a low-oxygen, high-nutrient environment.

Bulk density, measured both on the multisensor track (MST) and on discrete samples, increases with depth from $\sim 1.3$ to $2.0 \mathrm{~g} / \mathrm{cm}^{3}$, reflecting normal compaction. Core resistivities, derived from the MST, increase with depth to $\sim 60$ mbsf and thereafter remain constant. Porosities decrease from initial values of 
$\sim 80 \%$ to $\sim 50 \%$ near the bottom of the hole (Fig. F13). Peak shear strengths increase with depth as a result of increasing vertical effective stress and sediment consolidation (Fig. F13). The trend is relatively smooth from the seafloor to $\sim 80 \mathrm{mbsf}$; beneath 80 mbsf there is a sharp increase in undrained shear strength. The maximum peak strength recorded was $89 \mathrm{kPa}$.

Interstitial water chemistry shows large variations in alkalinity from 2.95 to $19.45 \mathrm{mM}$ with a downhole concave profile and a rapid increase to a maxima at 15 mbsf. pH shows a similar concave depth profile, but with a maximum at $\sim 30$ mbsf. Sulfate concentrations in interstitial water show rapid downhole depletion with a sulfate/methane interface (SMI) at 15 mbsf. The ionic concentrations of dissolved $\mathrm{Mn}^{2+}$ show a similar depletion trend as the sulfate concentration, whereas dissolved $\mathrm{Ba}, \mathrm{B}$, and $\mathrm{Si}$ show a concave-downward profile similar to those of alkalinity and $\mathrm{pH}$. The sharp pore water chemistry changes at shallow subseafloor depths suggest rapid anaerobic degradation of organic matter through sequential redox reactions within the uppermost $15 \mathrm{~m}$.

Average total organic carbon (TOC) content is relatively low for Gulf of Mexico sediments (0.75 wt\%), but this value is consistent with the relatively low microbial biomass encountered (maximum cell density observed $=1 \times 10^{6}$ cells $/ \mathrm{mL}$ ). Inorganic carbon concentrations are highly variable throughout the hole, ranging from 0.87 to $4.08 \mathrm{wt} \%$ (10.44 to 48.96 $\mathrm{wt} \% \mathrm{CaCO}_{3}$ ). The average $\mathrm{C} / \mathrm{N}$ ratio in the sediment was 3.77, suggesting either that algal material is the predominant source of organic matter or that the presence of inorganic nitrogen (such as ammonia) artificially lowers $\mathrm{C} / \mathrm{N}$ ratios. The $\mathrm{C} / \mathrm{N}$ maximum of 5.92 is coincident with the bottom of the sulfate reduction zone. The lack of any ethane $\left(\mathrm{C}_{2}\right)$ in headspace samples suggests that the relatively large quantities (as much as 11,310 ppmv) of methane (Fig. F13) detected are of biogenic, not thermogenic, origin.

Two deployments of the T2P were completed in Hole U1319A. The first deployment was at 1388 meters below sea level (41.6 $\mathrm{m}$ above seafloor) and provided a successful pressure test that demonstrated the tool could successfully pass through the lockable float valve of the bottom-hole assembly. Measured pressure $(13.76 \mathrm{MPa})$ was slightly below hydrostatic $(13.94 \mathrm{MPa})$, and the recorded water temperature was $4.9^{\circ} \mathrm{C}$. A second T2P deployment at $80.5 \mathrm{mbsf}$ recorded $1 \mathrm{~m}$ of penetration into the sediment. After $30 \mathrm{~min}$, the tip pressure was $15.49 \mathrm{MPa}$ and the shaft pressure $15.95 \mathrm{MPa}$; hydrostatic pressure was 15.19 $\mathrm{MPa}$ and formation temperature was $7.3^{\circ} \mathrm{C}$. Because of the nonvertical penetration of the T2P into the sediment, the tip of the tool was bent.

MWD/LWD operations were completed in Hole U1319B to 180 mbsf with data coverage by all MWD/LWD tools over the interval cored in Hole U1319A (0-157.5 mbsf). From the seafloor to 180 mbsf, the following trends were observed:

- Gamma radiation increases from 45 to 75 gAPI,

- Deep button resistivity increases from 0.6 to 1.8 $\Omega \mathrm{m}$ (Fig. F13),

- Porosity decreases from $75 \%$ to $50 \%$, and

- Bulk density increases from 1.4 to $2.0 \mathrm{~g} / \mathrm{cm}^{3}$.

These data suggest a normal compaction trend in the clay-rich section of Site U1319 (Fig. F13). Deviations from this trend occur at 25 mbsf where gamma radiation shows a step decrease (top of Unit III, foraminifer-rich clay), at 30.5-31.5 mbsf where gamma radiation increases (onset of fine laminae of sand, Unit IV), and at 78-93 mbsf where bulk density decreases (consistent with physical properties observed in the cores).

Drilling objectives at Site U1319 were fully accomplished. The almost continuous coring, lithostratigraphic, biostratigraphic, and logging records make Site U1319 an important reference location for study of sediment compaction. The low thermal gradient $\left(\sim 20^{\circ} \mathrm{C} / \mathrm{km}\right)$ was striking. Finally, the ability to detect individual lithostratigraphic units within the uppermost 30 mbsf allowed us to date, describe, and correlate these turbidite deposits to the other Brazos-Trinity Basin IV sites.

\section{Site U1320}

Site U1320 is located near the center of Brazos-Trinity Basin IV (Fig. F5). The main drilling objective at this site was to establish a reference section to determine the rock and fluid properties in a normally pressured basin. Secondary objectives included improving the age model for Brazos-Trinity Basin IV and studying turbidite deposits. Hole U1320A was continuously cored and wireline logged to a TD of 299.6 mbsf. A MWD/LWD-dedicated second hole (Hole U1320B) was then drilled to a TD of 320 mbsf.

The lower part of the sedimentary succession in Hole U1320A (Fig. F14) (lithostratigraphic Unit V) is dominated by clay with rare silt laminae often containing fragments of foraminifers. Most of the succession is intensely bioturbated. We interpret lithostratigraphic Unit V as hemipelagic sedimentation with a high influx of siliciclastic material derived from either river plumes and/or very low density turbidity currents. Above lithostratigraphic Unit V, Unit IV is 
dominated by clay and represents the initial pulse of turbidite influx into the Brazos-Trinity Basin IV. Lithostratigraphic Unit III consists of a foraminiferand nannofossil-bearing light greenish gray clay that contains volcanic ash Layer Y8, the product of the Los Chocoyos (Guatemala) eruption dated at $84 \mathrm{ka}$ (Drexler et al., 1980; Mallarino et al., in press). Lithostratigraphic Unit II represents the main phase of basin filling and is defined by a $135 \mathrm{~m}$ thick succession of both sandy and muddy turbidites and muddy MTDs. Lithostratigraphic Unit I consists of a thin veneer of Holocene hemipelagic sediments. The overall basin fill succession shows a general upward increase in proportion of sand and thickness of turbidite packages (Fig. F14).

Site U1320 yielded rare to abundant assemblages of calcareous microfossils spanning the late Pleistocene-Holocene in MIS 1-6. Tropical-subtropical species dominate the interglacial assemblages, whereas cool-temperate species are more common in assemblages from glacial intervals. Intervals deposited during MIS 5 show no reworked nannofossils, indicating a quiet open-marine environment during sea level highstands. Frequent small thinshelled benthic species of Bolivina and Bulimina are found in the lower part of Hole U1320A, suggesting that low-oxygen, nutrient-rich bottom conditions prevailed during MIS 6 in Brazos-Trinity Basin IV.

Lithostratigraphic Units I-III are characterized by considerable scatter in porosity values $(36 \%-71 \%)$ (Fig. F14). This is interpreted to result from variations in lithofacies, in particular the presence or absence of sandy intervals. Lithostratigraphic Units IV and $\mathrm{V}$ are characterized by a gradual decline in porosity with depth. This porosity decrease drives increases in thermal conductivity, magnetic susceptibility, and resistivity. Bulk density values increase with depth from $1.4 \mathrm{~g} / \mathrm{cm}^{3}$ at the seafloor to $2.0 \mathrm{~g} /$ $\mathrm{cm}^{3}$ at 273 mbsf. Grain density variations are small (between 2.6 and $2.8 \mathrm{~g} / \mathrm{cm}^{3}$ ). Thermal conductivity values increase with depth from 1.1 to $1.3 \mathrm{~W} /(\mathrm{m} \cdot \mathrm{K})$.

Pore water chemistry data in Hole U1320A suggest that rapid anaerobic degradation of organic matter occurred through sequential oxidation fronts at shallow depths. However, chemical changes in deeper sections of the hole point to diagenetic processes and/or deep-seated fluid flow. Rapid changes in interstitial water profiles occur at shallow depths within the upper part of lithostratigraphic Unit II (uppermost $40 \mathrm{mbsf}$ ). The decrease in $\mathrm{SO}_{4}{ }^{2-}$ from approximately ambient seawater concentration of 24.4 $\mathrm{mM}$ to a minimum of $0.5 \mathrm{mM}$ at $21.5 \mathrm{mbsf}$ coincides with an increase in alkalinity from 4.77 to a maximum of $15.99 \mathrm{mM}$ at 20 mbsf. $\mathrm{Mn}^{2+}$ concentrations also decrease downhole to a minimum of $1.37 \mathrm{mM}$ at 34.5 mbsf. Salinity and $\mathrm{Ca}^{2+}, \mathrm{Mg}^{2+}, \mathrm{K}^{+}, \mathrm{Li}^{+}$, and $\mathrm{Sr}^{2+}$ decrease with depth to 40 mbsf. In lithostratigraphic Unit V, significant increases in $\mathrm{Ca}^{2+}$ and $\mathrm{Sr}^{2+}$ correspond with a decrease in $\mathrm{Li}^{+}$concentrations. $\mathrm{Ba}^{2+}$ has a maximum concentration between 120 and 180 mbsf (lithostratigraphic Units III and IV).

The average TOC content $(0.53 \mathrm{wt} \%)$ is consistent with concentrations observed in Hole U1320A and is estimated to be either primarily derived from algal material (average $\mathrm{C} / \mathrm{N}=4.21$ ) or to contain a substantial amount of inorganic (bound) nitrogen that lowered the $\mathrm{C} / \mathrm{N}$ ratio. Trends in total inorganic carbon, TOC, total nitrogen (TN), C/N, and total hydrogen $(\mathrm{TH})$ data clearly correlate with seismic reflector surfaces R10 and R20. The highest concentration of methane $(57,714.2 \mathrm{ppm})$ is observed at $122 \mathrm{mbsf}$ (Fig. F14). Methane to ethane ratios $\left(\mathrm{C}_{1} / \mathrm{C}_{2}\right)$ are very high, suggesting a biogenic origin for methane. The calculated SMI depth is 22 mbsf. The inverse correlation between sulfate and methane gradients suggests local methanogenesis; however, the low microbial biomass $\left(1 \times 10^{6}\right.$ cells $\left./ \mathrm{mL}\right)$ cannot support in situ production of large amounts of methane.

Two deployments of the T2P were completed in Hole U1320A. The first deployment was at $126.3 \mathrm{mbsf}$ (below Core 308-U1320A-15X) and the second deployment was at 213.0 mbsf (below Core 308-U1320A24X). Both deployments used the tapered needle probe. The first deployment was completed with the drill bit $\sim 1 \mathrm{~m}$ from the bottom of the hole and used the drill string to push the T2P into the formation. The needle probe was bent slightly during this deployment, and the pressure transducer did not record data. The second deployment was also completed with the drill bit $1 \mathrm{~m}$ above the bottom of the hole, but instead of using the pressure of the drill string, the tool string weight was used to insert the probe into the formation. All transducers performed well during this deployment, and the T2P was retrieved without damage. Both deployments recorded pressures that were slightly below hydrostatic. The temperature gradient between the two deployments was $20^{\circ} \mathrm{C} / \mathrm{km}$.

From the seafloor to 177 mbsf, resistivity, gamma ray, and porosity logs from downhole logging operations delineate a series of interbedded sand and mud facies that correspond to lithostratigraphic Unit II (Fig. F14). Porosities decrease with depth from 87\% to $\sim 45 \%$ at a TD of 297 mbsf. LWD resistivity images of the borehole show apparent east-west-oriented breakouts at the bottom of the hole.

All primary and secondary drilling objectives were accomplished at Site U1320. Drilling results from this site, together with those from Site U1319, provide key information on the space-time evolution of 
sedimentary and geochemical systems in BrazosTrinity Basin IV and on the range of variation for physical properties for this basin.

\section{Site U1321}

Site U1321 is located on the southern edge of BrazosTrinity Basin IV within a section of basin turbidites underlain by a thicker section of hemipelagic mud (Figs. F5, F6). Hole U1321A was drilled as a dedicated MWD/LWD hole for correlation between other sites and to document the lateral change in petrophysical properties of the fan units above seismic Reflector R40 (Fig. F6, F15). The LWD data indicate a facies of interbedded sand and mud that corresponds to lithostratigraphic Unit II in Hole U1320B. Porosity values from logging data (Fig. F15) decrease with depth from $80 \%$ to $45 \%$ at $\sim 34$ mbsf. Most of the units identified in the logs seem to be thinning with respect to the lithostratigraphic units identified in Hole U1320B. Resistivity images of the borehole show apparent east-west-oriented breakouts at the bottom of the hole, similar to those observed at Site U1320. These breakouts indicate a north-south maximum horizontal stress direction. The resistivity images also show a series of thin alternating resistive and conductive laminations that may represent variations in silt content. Steep features at the bottom of the hole have been identified as potential slump deposits or faulted blocks.

MWD/LWD operations at Site U1321 permit bed-bybed correlation between Sites U1319 and U1320 (see discussion in "Synthesis of Brazos-Trinity Basin IV geology").

\section{Site U1322}

Site U1322 is the easternmost site drilled in Ursa Basin during Expedition 308 (Fig. F8). Of the three sites in Ursa Basin, Site U1322 has the thinnest sediment cover above the Blue Unit (Fig. F11). The principal objectives of drilling Site U1322 were to document rock physical properties at the location of thin overburden above the Blue Unit, measure in situ formation temperature and pressure, document geochemical composition of the pore water, and establish a preliminary age model leading to an estimate of sedimentation rates at this location.

Hole U1322A was the first dedicated MWD/LWD hole in Ursa Basin. MWD/LWD operations were performed before coring because real-time pressure and lithology data were needed to determine if shallowwater flows were occurring during drilling. The MWD/LWD operation in Hole U1322A reached 238 mbsf without encountering any sand units. Hole quality remained good (average diameter $=26.9 \mathrm{~cm}$ ) for almost the entire borehole. Hole U1322A is characterized by relatively monotonous logging data, mostly indicating clay, mud, and rare silt (Fig. F16). Resistivity and gamma ray measurements show the highest variability and can be correlated to several units defined by visual observation of the cores (see below) and to seismic Reflectors S10 and S30. In particular, logging data support division of the lithostratigraphic column (Fig. F16) encountered in Hole U1322B into two lithostratigraphic units (Units I and II) and further division of lithostratigraphic Unit I into Subunits IA-ID. The synthetic seismogram for Hole U1322A demonstrates that the correlation between logging data and the high-resolution seismic matches only the uppermost 100 mbsf. Nevertheless, the overall quality of the time-depth model allows an approximate correlation of seismic reflections with observations in core and logging data. The resistivity images obtained reveal intervals of undisturbed sediments and contorted and faulted sediments. The most striking features are parallel eastwest-orientated contours of analog resistivity that may represent breakouts indicating the direction of the minimal horizontal stress.

Based on visual description of the cores in Hole $\mathrm{U} 1322 \mathrm{~B}$, the $234.5 \mathrm{~m}$ sediment succession was divided into two lithostratigraphic units (Fig. F16). The total depth of this succession ties closely to seismic Reflector S60-1322, and the boundary between lithostratigraphic Units I and II (125.8 mbsf) occurs just above the prominent seismic Reflector S30. Lithostratigraphic Unit I is dominated by clay locally interbedded with silt and is further divided into four subunits based on the occurrence of intervals composed of deformed sediment. Lithostratigraphic Unit II is characterized by alternating meter-scale intervals of deformed and coherently laminated clay and mud. The deformed mud intervals are composed of dipping beds, small-scale faults, recumbent folds, and mud clasts. Nine deformed intervals with thicknesses varying from 2 to $5 \mathrm{~m}$ were recognized based on the occurrence of undeformed mud layers at their base.

Nannofossil and planktonic foraminifer data indicate that the sediment sequence recovered at Site U1322 was deposited over the last 60 k.y., more specifically during MIS 1-4. It is difficult to constrain sedimentation rates because of the MTDs that compose much of this site. Sedimentation rates of $\sim 1-2$ $\mathrm{m} / \mathrm{k}$.y. were estimated for the intervals above 30 mbsf and between 125 and 185 mbsf. Between 30 and 125 mbsf and below 185 mbsf, sedimentation rates increased to $12 \mathrm{~m} / \mathrm{k}$.y. or possibly higher in the intervals of MTDs. Distinctive cyclic patterns were observed in the distribution of nannoplankton and 
foraminifers, indicating periodic influx of sediments from the Mississippi River. Persistent low-oxygenated "stress" environments due to rapid sedimentation allowed infaunal benthic foraminifers to thrive. A deltaic benthic foraminifer assemblage from the interval between 185 and 234 mbsf is similar to those that exist today along the shelf edge of the Mississippi Delta, suggesting a period of turbidity currents as levee overbank deposits.

Variations in physical properties correlate with lithostratigraphic units and seismic reflectors at Site U1322. The porosity profile (Fig. F16) shows a relatively rapid decrease from the seafloor to $30 \mathrm{mbsf}$ and then a more gentle decrease to TD. Within MTDs, the porosity is lower relative to undeformed intervals: the maximum porosity offset in MTDs is $\sim 5 \%$ relative to undeformed sediment.

The chemical composition of the interstitial waters at Site U1322 varies widely in the uppermost 100 mbsf, in particular around the boundary between seismic Reflectors S10 and S20. Alkalinity, pH, concentrations of $\mathrm{Ca}^{2+}, \mathrm{Sr}^{2+}, \mathrm{Li}^{+}$, and $\mathrm{B}^{3+}$ ions, and $\mathrm{NH}_{4}{ }^{+}$ have concave depth profiles with maxima centered around seismic Reflector S10. Above seismic Reflector S10, salinity and sulfate concentrations are consistently high and decrease rapidly between seismic Reflectors S10 and S20 associated with a decrease in several other elements such as $\mathrm{Ca}^{2+}, \mathrm{Mg}^{2+}, \mathrm{B}^{3+}, \mathrm{Li}^{+}$, and $\mathrm{Sr}^{2+}$. At Site U1322, the SMI is very deep (74 mbsf) and corresponds to a rapid increase in methane concentrations. Above the SMI, only minor amounts of methane (several parts per million by volume) were detected. The highest concentrations of methane $(29,536-51,001 \mathrm{ppmv})$ were observed between 75 and 129 mbsf (Fig. F16). Only trace amounts of ethane $(<3.4 \mathrm{ppmv})$ and ethylene $(<2.6$ ppmv) were detected in a few headspace samples. No higher hydrocarbons were detected at Site U1322. The high $C_{1} / C_{2}$ ratios suggest biogenic origin of the methane, which could derive from in situ microbial activities or hydrogeologically driven migration.

A maximum cell density of $4.0 \times 10^{5}$ cells $/ \mathrm{mL}$ was observed at 2.9 mbsf in Hole U1322B. Microbial abundances decreased with depth below the cell enumeration confidence limit of $1.0 \times 10^{4}$ cells $/ \mathrm{mL}$ at 74.5 mbsf. The extremely low cellular biomass at Site U1322 is consistent with low microbial abundances at Site U1324. A surprising observation is that microbial biomass in Ursa Basin is an order of magnitude lower than cell densities observed at Sites U1319 and U1320 in Brazos-Trinity Basin IV.

At this site, there was one high-quality DVTPP deployment at $236 \mathrm{mbsf}$ and one high-quality T2P deployment at 150 mbsf. These provided a reasonable record of in situ temperature and pressure for Site
U1322. Most of the other deployments recorded subhydrostatic pressures. Based on these results (or lack thereof), we decided to spend the remaining $36 \mathrm{~h}$ of operation time drilling an additional geotechnical hole at this site. The purpose of the new Hole U1322D was to deploy the pressure and temperature probes and spot core after each deployment. The cores obtained were sampled for geotechnical analysis and then processed through the onboard laboratories.

All of the objectives set for Site U1322 were fulfilled. The principal result was that we acquired a good data set of formation pressures and temperatures that can be compared with those at Site U1324. T2P and DVTPP measurements at Site U1322 provided critical data for understanding overpressure and fluid flow in Ursa Basin. Pressure dissipation curves at Site U1322 (seven measurements) document overpressure starting at $50 \mathrm{mbsf}$ and continuing to TD. The temperature gradient at Site $\mathrm{U} 1322$ is $26.2^{\circ} \mathrm{C} / \mathrm{km}$.

\section{Site U1323}

Site U1323 is located between Sites U1322 and U1324 in Ursa Basin (Figs. F8, F11). The objectives of drilling at Site U1323 were to document rock physical properties at this location, measure in situ formation temperature and pressure, document geochemical composition of the pore water, and establish a preliminary age model leading to an estimate of sedimentation rates at this location. Site U1323 was logged using MWD/LWD and ultimately was not cored because an overpressured sand was encountered during MWD/LWD operations at a relatively shallow depth.

MWD/LWD operations at Site U1323 proceeded at an average penetration rate of $30 \mathrm{~m} / \mathrm{h}$, but borehole diameters were typically $>24 \mathrm{~cm}$ to a depth of 204 mbsf, where an overpressured sand was encountered. This sand body, $\sim 3 \mathrm{~m}$ thick, was detected at $204 \mathrm{mbsf}$ on the gamma ray log, and a simultaneous jump in pressure of 150 psi ( 1 MPa) over the background drilling pressure in the annular pressure-while-drilling log was observed. A residual backpressure of 150 psi was then observed by the driller when he shut down the mud pumps. At 242 mbsf, a rapid drop in the gamma ray log suggested the presence of another sand interval. At this point it was decided that to maximize the amount of science and conserve mud we should move to Site U1324 and plug and abandon Hole U1323A.

Logging and seismic data (Fig. F17) confirm that the upper $197 \mathrm{~m}$ interval is predominantly mud and clay rich, including two MTDs. Preliminary interpretation of the resistivity image data shows several highly deformed intervals confirming the original 
logging-seismic interpretation of several MTDs. These MTDs also display trademark characteristics of higher bulk density and resistivity compared with surrounding undeformed sediment.

Despite not coring at Site U1323, the high-quality logging data are valuable for analysis of the stratigraphic history of Ursa Basin. Drilling objectives for Site U1323 were thus achieved in three different ways: (1) overpressure was evidenced during MWD/ LWD operations, (2) the novel IODP approach to "riserless-controlled drilling" proved efficient in controlling the flow, and (3) data obtained at Site U1323 provide information on the lateral continuity and stratal architecture of Ursa Basin.

\section{Site U1324}

Site U1324 is the westernmost site drilled in Ursa Basin during Expedition 308 (Fig. F8). Of the three sites in Ursa Basin, Site U1324 has the thickest overburden above the overpressured Blue Unit. The principal objectives of drilling Site U1324 were to document rock physical properties, measure in situ formation temperature and pressure, document geochemical composition of the pore water, and establish an age model to estimate sedimentation rates.

The stratigraphy of Hole U1324A (Fig. F18) was first divided into two main logging units. These units were further divided into several subunits based on comparisons with nearby core data from Hole $\mathrm{U} 1324 \mathrm{~B}$ and variations in the logging responses. The main regional seismic reflectors (S10-S50) can be identified in the logging data as significant variations in velocity, gamma radiation, and/or resistivity (Fig. F18). The LWD resistivity images show a large degree of deformation, especially in logging Unit II. These images show significant folds and variable dips ranging from shallow to relatively steep $\left(>60^{\circ}\right)$, suggesting a significant amount of deformation within MTDs. Tilted beds, folds, and faults are dominated by a general east-west strike.

The $612 \mathrm{~m}$ thick sedimentary succession overlying the Blue Unit at Site U1324 records the evolution of the eastern levee of the Southwest Pass Canyon channel-levee system (Fig. F18). Visual observation of the cores supported the division of the succession into two lithostratigraphic units. Lithostratigraphic Unit I is composed of clay and mud and contains two MTDs. Lithostratigraphic Unit II is composed of interbedded silt, sand, and mud and contains at least three MTDs. Prior to Expedition 308, seismic facies analysis suggested that acoustically semitransparent intervals in lithostratigraphic Unit I represent regional MTDs composed of faulted and contorted masses of mud and clay. However, close examination of the cores reveals that these MTDs contain levee clay and mud that are only mildly deformed and tilted and thus are interpreted to have not been transported very far from their original position.

Variations in physical properties correlate with lithostratigraphic units. The interbedded silt, sand, and mud and MTDs in lithostratigraphic Unit II are characterized by highly variable bulk density, porosity (Fig. F18), and peak shear strength. Physical properties show much less scatter in the uniform hemipelagic mud and clay in lithostratigraphic Unit I. MAD bulk densities are consistent with those measured by MST and LWD in lithostratigraphic Unit I. A porosity increase at 40 mbsf correlates with seismic Reflector S10. A decrease in resistivity and low thermal conductivity were also observed at that depth. A sharp porosity increase at $\sim 160 \mathrm{mbsf}$ is related to the silt layer above seismic Reflector S30 (Fig. F18), which may be significantly overpressured. This explanation is supported by the observed decrease in $P$-wave velocity, thermal conductivity, and undrained shear strength at this depth.

Nannofossils and planktonic foraminifer assemblages as well as magnetostratigraphy indicate that the sediment sequence recovered at Site U1324 was deposited over the last 60 k.y., more specifically during MIS 1-4. Sedimentation rates varied between 5 and $>10 \mathrm{~m} / \mathrm{k}$.y. for lithostratigraphic Unit I in the interval above 365 mbsf of Hole U1324B, with possible sedimentation rate peaks of $12 \mathrm{~m} / \mathrm{k} . \mathrm{y}$. or more in the intervals of mass flow. Between 365 and 608 mbsf, in lithostratigraphic Unit II, sedimentation rates appear to have been higher, perhaps in excess of $25 \mathrm{~m} / \mathrm{k}$.y. However, the low microfossil abundance and the relatively young age of the sediments render precise dating of this interval difficult. Distinctive cyclic patterns were observed in the distribution of nannoplankton and foraminifers, indicating periodic influx of turbidites sourced from the Mississippi River. The infauna-dominated benthic foraminifer assemblages also suggest a prevalence of low-oxygenated "stress" environments due to rapid sedimentation during the last glacial period.

Variations in interstitial water chemistry at Site U1324 are largest at shallow depths ( $<100$ mbsf). Below this depth, limited changes are observed. Pore water chemical changes are particularly important from the seafloor to seismic Reflector S10 ( 35 mbsf). $\mathrm{Li}^{+}, \mathrm{B}^{3+}$, and $\mathrm{Sr}^{2+}$ reach their maxima within this depth range, and $\mathrm{Mn}^{2+}$ reaches its minimum at $\sim 35-$ 40 mbsf. $\mathrm{H}_{4} \mathrm{SiO}_{4}$ and $\mathrm{Fe}^{2+}$ reach their maxima between 20 and 25 mbsf. Between 40 and $160 \mathrm{mbsf}$, salinity, $\mathrm{Li}^{+}, \mathrm{B}^{3+}$, and $\mathrm{Sr}^{2+}$ decrease; $\mathrm{Ba}^{2+}, \mathrm{Fe}^{2+}$, and $\mathrm{NH}_{4}{ }^{+}$ increase; and $\mathrm{Cl}^{-}, \mathrm{Mn}^{2+}$, and $\mathrm{H}_{4} \mathrm{SiO}_{4}$ are constant. The extremely high ammonium contents (up to 6820 
$\mu \mathrm{M})$ in pore water are consistent with more reducing conditions at this site compared with the sites in Brazos-Trinity Basin IV. The downhole increase in ammonium likely reflects enhanced organic degradation at greater depths. The vertical profile, especially the surficial maximum and minimum in dissolved $\mathrm{Fe}^{2+}$ and $\mathrm{Mn}^{2+}$, are consistent with the hierarchy of redox reactions often observed in deep-marine sediments. The high $\mathrm{Fe}^{2+}$ contents at shallow depths might reflect enhanced $\mathrm{Fe}^{2+}$ reduction and/or greater availability of detrital $\mathrm{Fe}^{2+}$ oxides/oxyhydroxides or simply Fe-rich clays. The pore water chemistry is probably dominated by dissolution processes rather than by organic matter degradation, which enhances alkalinity, $\mathrm{Ca}^{2+}, \mathrm{Mg}^{2+}, \mathrm{Sr}^{2+}, \mathrm{B}^{3+}$, and $\mathrm{Li}^{+}$concentrations at $\sim 35$ mbsf. The causes for relatively acidic pore water $(\mathrm{pH}<7.0)$ above 200 mbsf at Site U1324 are unclear.

Methane concentration (Fig. F18) increases dramatically in the middle section of lithostratigraphic Unit I (160 mbsf) but remains low in the rest of the hole. The predominant hydrocarbon found in Hole $\mathrm{U} 1324 \mathrm{~B}$ was methane, and the $\mathrm{C}_{1} / \mathrm{C}_{2}$ ratios were high, suggesting a biogenic origin. Therefore, we interpret the methane found at Site U1324 as resulting from in situ microbial activities or, alternatively, as having migrated from lateral locations. The microbial cell count at Site U1324 was low, with a maximum cell density of $2.0 \times 10^{5}$ cells $/ \mathrm{mL}$ at $2.8 \mathrm{mbsf}$. This is an extremely low and unexpected value considering the location and high sedimentation rate of this site. The predominance of clay-rich sediment at Site U1324 may prevent fluid migration and inhibit the development of microbial communities.

In situ measurements made with the T2P and DVTPP documented fluid overpressure and a low temperature gradient at Site U1324 relative to the gradient at Site U1327. Successful fluid pressure measurements at $117,300,405$, and 608 mbsf yielded values for $\lambda^{*}$ between 0.2 and $0.6\left(\lambda^{*}=\right.$ ratio of overpressure to vertical hydrostatic effective stress). Eighteen temperature measurements constrain a geothermal gradient of $\sim 18.4^{\circ} \mathrm{C} / \mathrm{km}$.

All of the objectives for Site U1324 were fulfilled. The principal result is that we acquired a good data set of formation pressures and temperatures with which to compare Site U1322. Results from lithostratigraphy and biostratigraphy indicated very high sedimentation rates.

\section{Discussion and conclusions}

\section{Challenges of drilling in overpressured basins}

Expedition 308 was the first expedition in IODP/ ODP/DSDP history during which large volumes of weighted mud were used as part of the experimental design to achieve the scientific goals of the expedition (Fig. F19). Prior to the expedition, it was determined that there was a significant probability of encountering shallow-water flow in the subsurface. Shallow-water flow occurs when overpressured and unconsolidated sands flow into the borehole. Ultimately, shallow-water flow can compromise the integrity of boreholes and sands can be expelled at the seafloor.

To counter this possibility, weighted muds were used during drilling. The weighted mud is pumped down to drilling depths and ultimately expelled back up to the seafloor (Fig. F20). The effect of the weighted mud is to create a higher pressure within the annulus, which offsets the overpressure within the formation. During Expedition 308, a weighted mud composed of barite, sepiolite, and seawater was used at Sites U1323 and U1324, two of the sites where shallow-water flow was considered a significant risk. In these locations, 10.5 ppg mud was generally used. Shallow-water flow was, in fact, encountered in Hole U1323A at 200 mbsf while drilling with seawater (Fig. F21). An abrupt increase in pressure associated with a thin sand (indicated in the gamma ray $\log$ ) was identified. After raising the mud weight in the borehole, we drilled forward some distance before ultimately killing the flow with 13.5 ppg mud, whereupon we cemented the hole with 14 ppg mud. Table T1 illustrates the approximate volumes, durations, and depth ranges that mud was used.

In addition to the need to drill the borehole safely, weighted mud was also used to stabilize the hole for long-term deployments of penetrometers (DVTPP and T2P). In this case, the weighted mud was extremely useful for keeping the hole open. Because the formation is relatively plastic, over time it has a tendency to close on the drill string. Thus, there is a danger when one is not rotating or circulating fluid that the hole will close on the drill string. In Ursa Basin, this began to happen when seawater was in the hole at depths below 50 mbsf. However, when 10.5 ppg weighted mud was used, this problem was greatly reduced. This allowed us to make prolonged penetrometer measurements. In these cases, the borehole stability was striking. We ran some DVTPP deployments for $>1.5 \mathrm{~h}$ and experienced no problems with borehole closure. These deployments were far longer than previous deployments of downhole tools in IODP/ODP history. Typically it took 40-70 $\mathrm{bbl}$ of weighted mud to be spotted in the hole during a penetration deployment.

\section{Challenges of measuring pressure}

A critical goal of Expedition 308 was to measure pressure within mudstones using a penetrometer. 
Two tools were used for this task: the DVTPP and the T2P (Fig. F22). The DVTPP was deployed previously during ODP Legs 190, 201, and 204 (Moore et al., 2001; D'Hondt, Jørgensen, Miller, et al., 2003; Tréhu, Bohrmann, Rack, Torres, et al., 2003). The T2P is a new tool developed as a cooperative effort between MIT, the Pennsylvania State University, and IODPTAMU. The DVTPP and the T2P are similar devices. The primary difference between the two tools is that the T2P has a $6 \mathrm{~mm}$ diameter tip, whereas the DVTPP has a $\sim 23 \mathrm{~mm}$ diameter tip that rapidly widens backward from the tip. The T2P was designed both to dissipate more rapidly and to dissipate with a characteristic pressure profile. Both properties allow the T2P to be deployed for shorter periods than the DVTPP in order to interpret in situ pressures.

These penetration tools induce a pressure pulse as they are inserted into the sediment. The initial pressure response and its decay are defined by the insertion rate of the probe, the modulus of the sediment, and the bulk permeability of the sediment. The pressure dissipation that results after penetration is used to infer in situ pressure and rock properties (Fig. F23A).

Pressure measurements during Expedition 308 were extremely challenging. There were significant successes that allowed us to define the pressure gradient in Ursa Basin. There were a total of 25 T2P deployments and 20 DVTPP deployments (Fig. F24). Of these only $56 \%$ of the T2P and $45 \%$ of the DVTPP deployments were either fair or good and there were many poor or unsuccessful deployments (Fig. F24). Key problems were threefold. First, in early cases, there was a leak in one of the DVTPP tools and there may have been a leak in one of the T2P tools (e.g., Fig. F23C). The leak resulted in abrupt pressure drops below hydrostatic pressure during the dissipation phase. Second, the T2P was prone to bending due to the very narrow diameter tip. Third, both tools had difficulty remaining coupled to the sediments during deployment in the shallow sections (Figs. F23B, F25). During many of the deployments, after the drill string was raised and subsequent to penetration there was an abrupt drop in pore pressure. In these cases, there was often a frictional heating pulse associated with the drill string being raised. In addition, the accelerometer in the DVTP suggests movement of the tool when the drill string was raised. These results are interpreted to record the partial dislodgment of the tool due to friction in the colleted delivery system (e.g., Fig. F25). Review of DVTPP records from Legs 201 and 204 suggest that both leakages and tool dislodgement during elevation of the drill string have been a persistent problem with the DVTPP (D'Hondt, Jørgensen, Miller, et al., 2003; Tréhu, Bohrmann, Rack, Torres, et al., 2003).

\section{Synthesis of Brazos-Trinity Basin IV geology}

\section{Summary of principal results}

Brazos-Trinity Basin IV contains a succession of sand-rich turbidite fans, MTDs, and hemipelagic sediments deposited within the last $\sim 122$ k.y. Prefan deposits dating back to MIS 6 form a conformable succession of laminated and bioturbated clays deposited from distal low-density turbidity currents and/or river plumes. The initial turbidite deposits in the basin are mud rich, with the exception of the very first turbidity currents to enter the basin. This initial pulse, possibly derived from failure of older shelf edge deposits, accumulated an $8 \mathrm{~m}$ thick sand-rich interval. A basin-wide pause in turbidity current influx spans 30-40 k.y. between late MIS 5 and MIS 4/ 3. During MIS 3-2, a thick succession of sand-rich fans accumulated in Brazos-Trinity Basin IV, containing 2-25 $\mathrm{m}$ thick packets of very fine to lower medium sand beds. A 2-3 m microfossil-rich clay marks the end of turbidity current influx into the basin during the Holocene.

\section{Background of Brazos-Trinity region}

Brazos-Trinity Basin IV is the terminal basin of a series of bowl-shaped basins on the upper-middle continental slope that are linked to late Pleistocene shelf edge deltas by a network of submarine channels offshore Texas (Fig. F4). The fluvial, shelf, and slope portions of the Brazos-Trinity drainage system represent a natural laboratory to investigate the mechanics of sediment transfer across a continental margin from source to sink. Originally studied with sparse seismic records and piston cores (Gardiner, 1986; Satterfield, 1988; Satterfield and Behrens, 1990), the basin has been the subject of numerous detailed studies by the industry and academia (Winker, 1996; Beaubouef and Friedman, 2000; Pirmez et al., 2000; Badalini et al., 2000; Beaubouef et al., 2003; Mallarino et al., in press). Industry studies have focused particularly on the stratigraphic architecture of the intraslope basins because of their similarity with deepwater reservoirs formed on continental margins with a mobile (salt or shale) substrate. The shallow burial depths of such near-seafloor analogs allow for exceptional vertical and spatial resolution through the use of very high frequency $(>150 \mathrm{~Hz})$, short-offset seismic profiles. Studies to date have focused on the mapping of sequences using both 2-D grids and 3 -D seismic data, resulting in the development of stratigraphic models derived from the interpretation of seismic geometry, acoustic facies, and seismic attributes (Winker, 1996; Badalini et al., 2000; Beaubouef et al., 2003). 
Lithologic calibration of these basin-fill models has been limited to short piston cores (e.g., Satterfield and Behrens, 1990). More recently, Mallarino et al. (in press) report on a series of long piston cores in Brazos-Trinity Basin IV, but the recovery was limited to the upper $\sim 5$ to $\sim 25 \mathrm{~m}$ in the sandy basin fill, although successful cores up to $42 \mathrm{~m}$ long were obtained in the basin margins. The basin margin cores enabled Mallarino et al. (in press) to develop a highresolution chronostratigraphy for the upper part of the basin fill, dating to $\sim 90 \mathrm{ka}$.

Expedition 308 successfully acquired cores and a full suite of downhole logs that, for the first time, sample the entire infill of Brazos-Trinity Basin IV and underlying conformable succession along a transect from the basin center to the basin margin (Fig. F6). This unique data set provides a detailed characterization of the sediment gravity flow deposits and hemipelagic successions within the basin fill and allows for the age dating of the various fan sequences.

\section{Seismic stratigraphy}

The Brazos-Trinity Basin IV transect was drilled on a dip-oriented seismic line from the basin entry point to the east and across the thickest portion of the basin fill (Fig. F26). The short-offset multichannel seismic line has a frequency content in the range of $100-500 \mathrm{~Hz}$ with peak frequency at $\sim 300 \mathrm{~Hz}$ (Winker, 1996). Seismic Reflector R40 separates two distinct units: a conformable succession of subparallel reflections below and an onlapping succession representing the infill of Brazos-Trinity Basin IV above. The underlying succession appears to thicken gradually toward the northern basin margin. The basin fill succession displays an alternation of acoustically transparent intervals with packages displaying high-amplitude continuous to semicontinuous reflections. Previous workers interpreted these seismic facies as the result of the alternation between muddy mass transport complexes (transparent intervals) and sandy turbidite fans (bedded intervals) (Winker, 1996; Badalini et al., 2000; Beaubouef and Friedmann, 2000).

Well logs from Sites U1319, U1320, and U1321 are posted on the dip seismic line in Figure F26. The integration between log-core and high-resolution seismic makes it possible to confidently correlate stratigraphic units up to a few meters thick and to estimate the lateral extent of individual mud and sand packets away from the boreholes (Fig. F27). The match between lithostratigraphic boundaries and most key reflectors in the basin using the preliminary shipboard results is quite good (Fig. F26, F27).

Seismic Reflector R40 represents an angular unconformity at the base of the basin infill and can be traced continuously across the entire area. Seismic Reflector R30 marks an angular unconformity within the basin fill. A thin interval of parallel reflections forms a laterally continuous marker locally disrupted by an acoustically transparent/chaotic unit. Seismic Reflectors R10 and R20 are continuous reflections that separate acoustically transparent/chaotic intervals from intervals of high acoustic amplitude with reflections ranging from laterally continuous to discontinuous. Winker (1996) showed that sediments between seismic Reflectors R40 and R10 are sourced from the western feeder channel and sediments above seismic Reflector R10 were sourced from the eastern feeder channel.

\section{Stratigraphic evolution}

A preliminary age model was developed by integrating microfossil biostratigraphy together with correlation of magnetic susceptibility and NRM intensity data with global curves (Fig. F28). Tephra event Y8 (Drexler et al., 1980; Mallarino et al., in press) was recovered at both Sites U1319 and U1320, providing an absolute correlation and age marker. The entire drilled succession appears to be younger than $150 \mathrm{ka}$ since the last occurrence (LO) datum of Helicosphaera inversa was not observed at the bottom of Holes U1319A and U1320A. The base of the basin infill occurs near the planktonic foraminifer Zone W/X boundary, at $\sim 122 \mathrm{ka}$, and coincides with a $\sim 2 \mathrm{~m}$ thick condensed hemipelagic interval. A pause in turbidity current influx also occurs within the basin fill and spans a $\sim 40$ k.y. period from $\sim 90$ to $\sim 50 \mathrm{ka}$ (Mallarino et al., in press). The LO of Globorotalia flexuosa at $\sim 68 \mathrm{ka}$ is observed at both Sites U1319 and U1320, but based on seismic correlation and the occurrence of $G$. flexuosa within the turbidite infill section at Site U1320, it is likely the result of reworking by turbidity currents.

Integration of the lithostratigraphy, biostratigraphy, logging characteristics, and seismic stratigraphic correlations are summarized in a structural cross section (Fig. F29). Examples of core photographs of the lithofacies encountered in each of the Brazos-Trinity Basin IV sequences are illustrated in Figure F30.

The following summarizes the basin stratigraphic architecture and evolution, from oldest to youngest.

\section{Prefan sequence}

All three sites penetrated a succession of laterally extensive subparallel reflectors below seismic Reflector $\mathrm{R} 40$ at the base of the basin infill. This succession is composed of terrigenous laminated clay with color banding between grayish green and reddish brown and varying degrees of bioturbation (Fig. F30E). These clays have a low TOC content (average $=0.5$ 
wt $\%$ ) but are rich in $\mathrm{CaCO}_{3}$ (average $=23 \mathrm{wt} \%$ ), most of which is associated with fine-grained detrital carbonate and dolomite. The unit is devoid of sand and contains very rare silt laminae.

The $125 \mathrm{~m}$ thick prefan deposits cored at Sites U1319 and $\mathrm{U} 1320$ are interpreted to be younger than $150 \mathrm{ka}$ and were deposited at an average rate of $>4 \mathrm{~m} / \mathrm{k} . \mathrm{y}$. This succession is interpreted to represent deposition from distal turbidity currents overspilling from basins adjacent to Brazos-Trinity Basin IV (laterally and/or updip), possibly with a significant contribution from sedimentation from surface plumes of coastal rivers.

\section{Hemipelagic drape-base of infill}

Capping the prefan deposits is a $\sim 2 \mathrm{~m}$ thick intensely bioturbated microfossil-bearing clay recovered at Site U1319 (Fig. F30D). At Site U1320, the same interval occurs within a zone of poor core recovery. This condensed interval marks a dramatic reduction of terrigenous sediment flux to the basin and occurs at the base of the onlap fill of Brazos-Trinity Basin IV. We interpret this condensed interval to represent the sea level highstand during MIS 5e. Seismic correlation of the regional seismic Reflector R40 between the two sites indicates that this condensed interval represents the base of Brazos-Trinity Basin IV infill.

\section{Lower fan-seismic Reflectors $R 40-R 30$}

The lower fan unit in Brazos-Trinity Basin IV thins very gradually onto the basin margin, from $30 \mathrm{~m}$ at Site U1320 to $\sim 10 \mathrm{~m}$ at Sites U1321 and U1319. The sequence is dominated by laminated and bioturbated muds with thin beds of silt and sand (Fig. F30C). Sand content decreases from $\sim 23 \%$ at Site U1320 to only a few percent at Site U1319. Most of the sand occurs in a $\sim 8 \mathrm{~m}$ thick interval of poor recovery at the base of the lower fan at Site U1320. This basal sand varies in thickness along the $20 \mathrm{~m}$ that separates Holes U1320A and U1320B. This probably represents the infill of an erosional scour or channel. Excluding this basal sand, the lower fan has a sand content of only $8 \%$.

The mud-rich lower fan was deposited between $\sim 120$ and $\sim 90 \mathrm{ka}$. The first pulse of sandy turbidity currents appears to have occurred within MIS 5e or at the rapid sea level fall event marking the MIS 5e-5d transition. At that time, sea level was still higher than today and the coastline was far landward of the modern shelf edge. The source of this initial pulse of turbidites is inferred to result from remobilization of shelf edge sediments deposited from previous sea level lowstands or from submarine failures in the updip basins.

\section{Hemipelagic drape_-base of middle fan}

The lower fan is capped by an $\sim 8 \mathrm{~m}$ thick interval of foraminifer- and nannofossil- bearing clay displaying intense bioturbation, similar to the hemipelagic drape at the base of the lower fan (Fig. F30B). Near the base of this hemipelagic drape, a $2 \mathrm{~cm}$ thick layer of volcanic glass shards was observed at both Sites U1319 and U1320. This ash layer provides an independent correlation and age marker confirmed by the Emiliana huxleyi acme in close proximity to the ash. This ash layer is interpreted as tephra event Y8, representing the outfall from the Los Chocoyos (Guatemala) eruption at $84 \mathrm{ka}$ (Drexler et al., 1980; Mallarino et al., in press). Seismic Reflector R30 occurs at the top of this interval and can be laterally traced over most of the basin.

The duration of this basin-wide pause in sediment flux to Brazos-Trinity Basin IV cannot be determined precisely. Mallarino et al. (in press) indicate that the pause in turbidite sedimentation may have lasted into early MIS 3, but earlier MIS 4 turbidites may not have reached the basin margin core site that Mallarino et al. (in press) studied. The paucity of terrigenous input into the basin during this interval, despite significant oscillations in sea level, is interpreted to indicate that either fluvio-deltaic input was directed away from the head of the system near Basin I or, alternatively, that turbidity currents were completely trapped in updip Basins I and II.

\section{Middle fan-seismic Reflectors R30-R10}

The middle fan comprises a succession of sediment gravity flow deposits including massive and normally graded fine to lower medium sand beds up to several meters thick interbedded with thinly laminated muds and silts.

The middle fan thins from $\sim 110 \mathrm{~m}$ at Site U1320 to $\sim 50 \mathrm{~m}$ at Site U1321 and to $\sim 12 \mathrm{~m}$ at Site U1319, illustrating the strong effect of basin margin topography on sand distribution. The lower part of the middle fan is represented by a very thin interval at Sites U1321 and U1319, whereas the upper part of the fan succession reaches higher onto the basin margin. At the base of the middle fan, an acoustically transparent interval corresponds to a slump/debris flow deposit containing contorted beds and mud clasts. This mass transport deposit originates from the basin margin to the east (Winker, 1996).

Average sand content of the middle fan unit is $\sim 40 \%$ at Site U1320, $\sim 80 \%$ at Site U1321, and only minor amounts of sand were recorded at the basin margin Site U1319. Sand distribution within the middle fan, however, is quite variable both vertically and spatially. At Site U1320, sand beds are organized in 2-10 
$m$ thick packets with an overall increase in sand content upward, particularly above seismic Reflector R20. The sand packets are capped by muds and intervals of laminated mud with thin bedded silts and sands. Some of these muddy intervals can be correlated across the transect, whereas others are either eroded away or pinch out between boreholes (Fig. F29).

The upper portion of the middle fan, above seismic Reflector R20, is the sandiest interval of the entire basin fill with amalgamated sand beds forming a 25 $\mathrm{m}$ thick unit at Site U1321 (Fig. F29). This interval is also remarkably transparent on seismic data reflection profiles (Fig. F26). At Site U1320, a sharp contact between a thick-bedded sand packet above a laminated, partly contorted interval of mud with thin beds of silt and sand correlates with a subtle seismic reflection. At Site U1321, this acoustically transparent interval is composed of $\sim 100 \%$ sand as interpreted from logs. Subtle reflections on the seismic lines suggest that the basal mud unit at Site U1320 is most likely eroded by channels and scours and is completely absent at Site U1321 (Figs. F26, F27).

Previous basin models derived from seismic facies analyses interpreted this transparent unit as muddy MTDs (e.g., Winker, 1996; Badalini et al., 2000; Beaubouef and Friedmann, 2000; Beaubouef et al., 2003). Detailed log-seismic-physical property analyses on shore are needed to unravel the low impedance contrasts within these shallowly buried muds and sands.

Capping the middle fan is a $\sim 10 \mathrm{~m}$ thick organic-rich homogeneous dark green to black clay with a sharp base and top. This unit thins onto the basin margin but appears to extend across the entire basin fill (Figs. F26, F27). It is interpreted to represent a debris flow deposit.

\section{Upper fan-seismic Reflector R10 to seafloor}

The upper fan comprises a sand-rich unit forming a tapered wedge across the basin. At Site U1320 it is $\sim 25 \mathrm{~m}$ thick and contains thick and medium beds of fine and very fine sand. The upper fan thins to $\sim 18$ $\mathrm{m}$ at Site U1321 and has similar logging characteristics but a slightly lower sand content than at Site U1320. The correlative unit at Site U1319 is only 3 $\mathrm{m}$ thick and is mostly mud with some thin beds of silt and sand. Sand beds in the upper fan are organized in bed packets ranging in thickness between 2 and $8 \mathrm{~m}$, capped by intervals of mud with thin beds. Correlation to seismic profiles (Fig. F27) shows that the sand packets represent mounded seismic bodies with internally discontinuous reflections representing fan lobes extending laterally for several kilome- ters. Beaubouef et al. (2003) show spectacular highresolution 3-D images from these channelized fan lobes. The upper fan is capped by a microfossil-rich clay, indicating that turbidity current deposition ceased in the basin during the last sea level rise.

The upper and middle fans were deposited between $\sim 47-60$ and $\sim 10 \mathrm{ka}$ and represent the main pulse of turbidity current influx into Brazos-Trinity Basin IV. This implies an average sedimentation rate between 2.5 and $3.5 \mathrm{~m} / \mathrm{k} . \mathrm{y}$. for the $130 \mathrm{~m}$ thick succession at Site U1320, compared with an average sedimentation rate of $\sim 0.2 \mathrm{~m} / \mathrm{k} . \mathrm{y}$. at basin margin Site U1319. Terrigenous influx was reduced dramatically throughout Brazos-Trinity Basin IV during the Holocene as indicated by the presence of a microfossilrich clay in the upper 2-3 m of the sediment column at both Brazos-Trinity Basin IV sites.

\section{Conclusions: evolution of Brazos-Trinity Basin IV}

Sedimentation in Brazos-Trinity Basin IV is the result of a complex interaction between fluvio-deltaic dynamics, sea level changes, and interactions between turbidity currents and submarine topography. During the low sea level period corresponding to MIS 6, the basin received significant input of terrigenous sediments, but a complete absence of sand and silt indicates that either turbidity currents were filling basins updip or that deltaic systems were positioned in areas adjacent to the Brazos-Trinity slope at the time.

During the stepwise sea level fall between MIS $5 \mathrm{e}$ and MIS 2, the basin received as much as $175 \mathrm{~m}$ of sediment gravity flow deposits comprising turbidites, slumps, and debris flows. A pause in turbidite deposition occurred from MIS 5a to MIS 4. This period comprised both a relative rise and a relative fall in sea level. Therefore the lack of turbidite influx into Brazos-Trinity Basin IV must be the result of factors other than sea level changes, including lateral shifts in the sediment source on the shelf or trapping of sediments in Basins I or II updip preventing the spillover of turbidity currents into Brazos-Trinity Basin IV.

Seismic facies-based interpretations of the basin fill architecture by previous authors are often contradictory, and our results provide the needed calibration to validate these interpretations. Seismic intervals that show abrupt onlap onto the basin margins generally correspond to sand-rich turbidites (e.g., middle fan above seismic Reflector R30), whereas those seismic units that have a gradual thinning pattern onto the basin margin tend to have lower sand content (e.g., lower fan between seismic Reflectors R40 and R30). The acoustically transparent units observed in the basin fill are composed of very high sand con- 
tent, ranging from $50 \%$ to $\sim 100 \%$, contradicting previous interpretations (e.g., Badalini et al., 2000; Beaubouef and Friedman, 2000; Beaubouef et al., 2003).

Mud-rich turbidite intervals appear to extend laterally for significant distances across the basin and rise as much as $\sim 50 \mathrm{~m}$ above the basin floor. This could result from turbidity current run-up onto the basin margins or represent a measure of the thickness of turbidity currents entering the basin. However, some of the relief, perhaps as much as $20 \mathrm{~m}$, appears to result from subsidence at the basin center since the onset of basin filling.

Overall, the sand content in the basin fill increases upward with the lowest sand content observed in the lowermost fan $(\sim 23 \%)$, but there is significant spatial variability in the profiles. The highest sand content is encountered in the southernmost edge of the basin at Site U1321, in the upper part of the middle fan. The sand content of the upper fan is high ( $60 \%-70 \%)$, but not as high as the upper part of the middle fan ( $77 \%$ to $100 \%)$. Although the general increase in sand content could be interpreted as the result of progressive sea level fall and advance of the Brazos-Trinity fluvial systems toward the shelf edge (e.g., Mallarino et al., in press), it is clear that lateral shifts in deltaic depocenters and trapping of sands in the updip basins also have an important influence in sand influx into Brazos-Trinity Basin IV.

\section{Synthesis of Ursa Basin geology}

At Sites U1322, U1323, and U1324, a sedimentary wedge flanking a buried submarine channel of the modern Mississippi Fan, the Southwest Pass Canyon channel-levee system, was investigated (Fig. F31). Of the two cored sites, Site U1324 penetrated the thickest part of the east levee. Site U1322, $12 \mathrm{~km}$ east, penetrated the thinner portion of the levee. The core descriptions and age results of these two sites, along with the lithostratigraphic column interpreted from the LWD data at Site U1323, provide the basis to evaluate the diverse sedimentary history of this system.

\section{Age constraints}

Nannofossils and planktonic foraminifers indicate that the sediment sequence recovered at Sites U1322 and U1324 was mainly deposited over the last $60 \mathrm{k.y}$. A good correlation can be made between the two sites using faunal assemblage zones and species datums (Fig. F32).

Sediment sections corresponding to lithostratigraphic Subunits IB (lower part) to ID at both sites (30-130 mbsf at Site U1322 and 30-170 mbsf at Site
U1324), between seismic Reflectors S10 and S30, are dated by planktonic foraminifers belonging to MIS 2 $(10-25 \mathrm{ka})$. The age control points are rare from the lower part of Holes U1322B and U1324B. However, fairly reliable planktonic foraminifer data indicate an MIS 3 age for sediments recovered at 130-190 mbsf at Site U1322 and 170-329 mbsf at Site U1324. Farther downhole, biostratigraphic constraints are inadequate to correlate between the two sites. The nonoccurrence of some datums older than 65 ka suggests that the sediment from the base of Sites U1322 and $\mathrm{U} 1324$ is younger than $65 \mathrm{ka}$. The rarity of microfossils in the lower part of the drilled section provides little specific information regarding species datums but does suggest that the sediment interval was deposited during sea level lowstands belonging to MIS 4 ( $60-65 \mathrm{ka})$. Results from previous studies, including Winker and Booth (2000), indicate that the last occurrence datum of $G$. flexuosa (68 ka) lies at the base of the Blue Unit, which is $2200 \mathrm{~m}$ deeper than the bottom of either Hole U1322B or Hole U1324B. Therefore, we believe that the sediment sequence recovered at both sites in Ursa Basin was deposited in the last 60 k.y., during MIS 1-4.

\section{Correlation and sedimentary history}

The upper $160 \mathrm{~m}$ of Site U1324 and the upper $135 \mathrm{~m}$ of Site U1322 are correlative. They consist of mud, clay, and two MTDs (Fig. F31). The base of these intervals ties closely with regional seismic Reflector S30 and is dated at $24 \mathrm{ka}$. Sedimentation rates during the accumulation of these correlative intervals at both Sites U1324 and U1322 were similar, ranging from 10 to $12 \mathrm{~m} / \mathrm{k} . \mathrm{y}$. and declining to lower rates in the uppermost Holocene (Fig. F32).

The base of the cored sections of Sites U1324 and U1322 ties closely with seismic Reflector S60 (Fig. F33), which we believe to be $\sim 60 \mathrm{ka}$ based on shipboard biostratigraphic and magnetostratigraphic analyses (Fig. F32). S60 is a reflector within the Ursa Canyon east and west levee and therefore should have been deposited approximately synchronously.

Although the upper portions of Sites U1322 and U1324 are similar, sections below contrast lithologically. Between seismic Reflectors S40-1324 and S60 at Site U1324, lithostratigraphic Unit II contains interbedded sand, silt, and mud, representing relatively unconfined flow turbidites deposited by a developing channel system. Above seismic Reflector S60 at Site U1322, lithostratigraphic Unit II contains a series of stacked clay- and mud-rich MTDs with a marked paucity of sand and silt. Apparently, the Ursa Canyon channel-levee system acted as a barrier that confined sand and silt at Site U1324 and effectively shielded Site U1322 from deposition. The Ursa Can- 
yon system would have had considerable topographic relief on the seafloor which would have confined sands, silt, and mud to the west during the accumulation of lithostratigraphic Unit II at Site U1324. Many seismic reflectors within the upper part of lithostratigraphic Unit II climb to the east up and over the top of the Ursa Canyon channel-levee system; therefore, we interpret there was very little sediment accumulation at Site U1322 before sediment breached the height of the Ursa Canyon system.

\section{Mass transport deposits and westward retrogressive failure}

During Expedition 308, we examined numerous cores containing MTDs. Inclined bedding planes, folds, and faults commonly characterize MTDs (Fig. F34). MTDs are recognized seismically by their discontinuous to chaotic reflections of transparent to variable amplitude (Fig. F34). Logging curves typically show positive anomalies in density and resistivity at the top of and within MTDs (Fig. F34). Resistivity images reveal striking folds and faults associated with MTDs and suggest north to south sediment transport.

The seismic cross section and the contrasting lithostratigraphic columns at Sites U1322 and U1324 suggest mass transport deposition was more active earlier to the east and progressively migrated upsection and to the west. The more rapid accumulation of sediments in the basal portion of Site U1324 relative to Site U1322 may have created a thickness imbalance that could have expelled pore fluid to the east, initiating failure.

\section{Physical properties in Brazos-Trinity IV and Ursa Basins}

Analyses of bulk density and porosity profiles suggest overpressure in the lower lithostratigraphic units near the depocenter of Brazos-Trinity Basin IV (Site U1320) and throughout Ursa Basin (Sites U1322, U1323 and U1324). The overpressure ratio is here defined as

$$
\lambda^{*}=\left(P-P_{\mathrm{h}}\right) /\left(\sigma_{\mathrm{v}}-P_{\mathrm{h}}\right),
$$

where

$P=$ pore pressure,

$P_{\mathrm{h}}=$ hydrostatic pressure, and

$\sigma_{v}=$ total vertical stress.

\section{Brazos-Trinity Basin IV}

Lithostratigraphic Unit V at Site U1320 and lithostratigraphic Unit VI at Site U1319 (both below seismic Reflector R40) are equivalent stratigraphic sec- tions that have been subject to different burial histories. Above seismic Reflector R40 at Site U1320, there is $178 \mathrm{~m}$ of overburden. In contrast at Site $\mathrm{U} 1319$, located on the basin's flank, there is only a few meters of overburden. Immediately below seismic Reflector R40, porosities are $\sim 65 \%$ at Site U1319 and $\sim 50 \%$ at Site U1320. At the bottom of the holes at both sites porosities are $\sim 40 \%$, although the overburden is higher at Site U1320 than at Site U1319 (Fig. F35).

Porosity $(\phi)$ relates to void ratio $(e)$ by the formula

$$
e=\phi /(100-\phi) \text {. }
$$

The pore pressure at Site U1320 is estimated from the differences in void ratio with respect to the vertical hydrostatic effective stress (Fig. F36) using the formula

$$
P=\sigma_{v}-10^{\left(e_{0}-e\right) / C_{c},}
$$

where

$$
\begin{aligned}
& P=\text { pore pressure predicted from the void ratio, } \\
& \sigma_{v}=\text { total vertical stress, } \\
& e=\text { measured void ratio, } \\
& \mathrm{e}_{0}=\text { reference void ratio }(3.49), \text { and } \\
& \mathrm{C}_{\mathrm{c}}=\text { compression index }(0.89) .
\end{aligned}
$$

Reference void ratio and compression index constants are derived from the curve fit of the data from Site U1319 in Figure F36. This approach is derived from standard geotechnical practice (e.g., Lambe and Whitman, 1969). We predict the difference in pore pressures between Sites U1319 and U1320 based on the assumption that both locations have similar stress-strain properties, that sediments at Site U1319 are normally pressured, and that sediments at both locations are normally consolidated (i.e., their in situ effective stress is their maximum past effective stress).

The overpressure ratio at Site U1320 that is estimated from the differences in void ratio with Site U1319 is approximately $\lambda^{*}=0.7$ (Fig. F36). This contrasts with the last value measured by the T2P, which recorded an overpressure ratio $\lambda^{*}=0.2$. Further consolidation tests in the laboratory and refined analysis of the T2P and DVTPP pore pressures will refine these estimates.

\section{Ursa Basin}

In Ursa Basin, lithostratigraphic Subunits IA-ID are correlative between Sites U1322, U1323, and U1324. Lithostratigraphic Subunits IB and ID are MTDs, whereas lithostratigraphic Subunits IA and IC are not disturbed. The lithostratigraphic units below seismic Reflector S30 are not equivalent at each site, and thus comparison is difficult. The thickness of the strata between the seafloor and seismic Reflector S30 
is $124 \mathrm{~m}$ at Site U1322, $197 \mathrm{~m}$ at Site U1323, and 165 $\mathrm{m}$ at Site U1324. Lithostratigraphic Subunits IA-ID have a similar thickness at all three sites and have comparable lithology and depositional history.

Sites U1322, U1323, and U1324 have similar porosity and bulk density in lithostratigraphic Unit I and therefore similar consolidation states (Fig. F37). The porosity profiles from the three sites show similar trends with a relatively rapid decrease in porosity from $80 \%$ at seafloor to $55 \%$ in lithostratigraphic Subunit IA (above seismic Reflector S10). Then, a gentler gradient is observed to the bottom of the hole, with the lowest porosities at $\sim 45 \%$.

It is assumed that lithostratigraphic Subunit IC at Site U1324 is hydrostatically pressured. The amount of overpressure at Sites U1322 and U1324 can be estimated through Equation 3. The reference void ratio $\left(\mathrm{e}_{0}=3.32\right)$ and compression index $\left(\mathrm{C}_{\mathrm{c}}=0.81\right)$ are obtained from the void ratio versus vertical hydrostatic effective stress plot of lithostratigraphic Subunit IC at Site U1324 (Fig. F38). The estimated overpressure is $\lambda^{*}=0.4-0.5$ of the vertical hydrostatic effective stress below seismic Reflector S30 at Site U1322 and $\lambda^{*}=0.6-0.7$ at Site U1324 (Fig. F38). The predicted pore pressures fit along the last recorded in situ pore pressure measurements from the T2P and DVTPP measurements. Further consolidation tests in the laboratory and refined analysis of the T2P and DVTPP pore pressures will refine these estimates.

At Site U1322, bulk densities are consistently higher in MTDs relative to undeformed deposits (Fig. F37). The bases of MTDs have lower porosities than the undeformed intervals immediately below. These decreases in porosity are accompanied by increases in undrained shear strength (e.g., Fig. F16) relative to undeformed deposits. The higher consolidation is inferred to result from dewatering during the landslide process. It is also observed that porosity and undrained shear strength at the top of MTDs do not vary significantly with respect to the sediments above. This might imply that dewatering and consolidation are focused at the base of the MTD where shearing is most likely.

Subunits ID and IB correspond to the same MTDs at Sites U1322 and U1324. The general trends in porosity and undrained shear strength were similar at both sites. However, the porosity and undrained shear strength profiles at Site U1324 (Fig. F18) show more subdued variations (or no variation at all) between the MTDs and undeformed units than those at Site U1322 (Fig. F16). We speculate that at Site U1324, shear deformation may have been less than at Site U1322.

The bases of MTDs appear to have high porosity and water content. An example is the interval that corre- lates with seismic Reflector S30 ( 160 mbsf at Site U1324) at the base of lithostratigraphic Subunit ID, a $35 \mathrm{~m}$ thick MTD (Fig. F37). This layer might have been the preferential weak layer along which the MTD initiated.

\section{Brazos-Trinity Basin IV versus Ursa Basin}

The porosities in Brazos-Trinity Basin IV and Ursa Basin show similar trends with depth (Fig. F39). The porosities in Ursa Basin are slightly lower in the uppermost $100 \mathrm{~m}$ of the sediment column and then decrease more gradually with depth than those in Brazos-Trinity Basin IV. It is not clear if the differences in the porosity trends are due to the differences in lithology at the two different locations, the difference in vertical hydrostatic effective stress, or a combination of these factors.

The results that can be obtained now are quantitative, but relative estimates are based on several assumptions. Processing the pore pressure measurements from the T2P and DVTPP, as well as the consolidation tests in the laboratory, will provide a better perspective of the overpressures in both basins and their hydrogeological regimes.

\section{Geochemical indicators of fluid flow}

The geochemistry of sediment pore water is indicative of the composition of the seawater trapped during sedimentation and is influenced by postdepositional diagenetic transformation and mixing with new water masses. As such, it is a potentially useful means of tracing fluid flow in Brazos-Trinity Basin IV and Ursa Basin. The 93 interstitial water samples collected from Brazos-Trinity Basin IV (51 at Site U1319 and 42 at site U1320) and the 124 samples from Ursa Basin (49 from Site U1322 and 75 from Site U1324) were analyzed shipboard for alkalinity, $\mathrm{pH}$, salinity, chlorinity, $\mathrm{SO}_{4}{ }^{2-}, \mathrm{PO}_{4}{ }^{3-}, \mathrm{NH}_{4}{ }^{+}, \mathrm{H}_{4} \mathrm{SiO}_{4}, \mathrm{Na}^{+}, \mathrm{K}^{+}, \mathrm{Mg}^{2+}$, $\mathrm{K}^{+}, \mathrm{B}^{3+}, \mathrm{Li}^{+}, \mathrm{Sr}^{2+}, \mathrm{Ba}^{2+}, \mathrm{Fe}^{2+}$, and $\mathrm{Mn}^{2+}$ concentrations (Figs. F40, F41).

Based on the fact that the maximal variation of the different tracers (Figs. F40, F41) is limited to the sediments of the uppermost 30 mbsf in Brazos-Trinity Basin IV and the uppermost 100 mbsf in Ursa Basin, we infer that organic degradation and microbially mediated reactions were restricted to these intervals. The pattern of anaerobic degradation of organic matter and the pore water redox conditions in both basins are characteristic of deep-marine sediment diagenesis (e.g., Schulz, 2000). The SMI occurs at shallower depths in Brazos-Trinity Basin IV Sites $\mathrm{U} 1319$ (SMI = $15 \mathrm{mbsf})$ and U1320 (SMI = $22 \mathrm{mbsf})$ than in Ursa Basin Sites U1322 (SMI = 74 mbsf) and $\mathrm{U} 1324$ (SMI = $94 \mathrm{mbsf}$ ). We infer that this difference 
is mainly driven by the higher sedimentation rates in Ursa Basin compared to Brazos-Trinity Basin IV. Pore water $\mathrm{SO}_{4}{ }^{2-}$ and $\mathrm{Mn}^{2+}$ concentrations within the sulfate reduction zone show a strong antithetical relationship at all sites. $\mathrm{NH}_{4}{ }^{+}$concentrations at the Ursa Basin sites increase with depth, suggesting that more reducing conditions may have existed at these locations relative to sites in Brazos-Trinity Basin IV.

Alkalinity has maxima at $\sim 35$ and 25 mbsf at Sites U1319 and U1320, respectively, in Brazos-Trinity Basin IV and at 26 and 47 mbsf at Site U1322 and U1324, respectively, in Ursa Basin. These maxima in alkalinity correlate with pore water increases in $\mathrm{Ca}^{2+}$, $\mathrm{Sr}^{2+}, \mathrm{B}^{3+}$, and $\mathrm{Li}^{+}$concentrations (Figs. F40, F41). We interpret this relationship as indicating diagenetic carbonate dissolution at shallow depths.

The strongest evidence supporting the presence of fluid flow is that seismic reflectors are often associated with pronounced changes in pore water chemistry, both in Brazos-Trinity Basin IV and Ursa Basin (Figs. F40, F41). This suggests that seismic surfaces occur along permeable stratigraphic horizons that acted as conduits focusing lateral fluid migration. At Site U1320 in Brazos-Trinity Basin IV, the changes in pore water chemistry are mainly related to seismic Reflectors R10 and R30, whereas at Site U1319, which is a more condensed sedimentary section located at the steep margin of the basin, these changes are restricted mostly around seismic Reflector R30 (Fig. F40). Below seismic Reflector R30, some of the element concentrations also show similar spikes associated with seismic reflectors such as the $\mathrm{Cl}^{-}$minimum between seismic Reflectors R50 and R60. This minimum may indicate lateral migration of slightly fresher fluid at this particular strata (Fig. F40). At Site U1324 in Ursa Basin, changes in pore water chemistry equivalent to those described above in BrazosTrinity Basin IV are centered around seismic Reflector S10 and below seismic Reflector S30 (Fig. F41). At Site U1322, the chemical changes around seismic Reflector S10 are similar to those observed at Site U1324, but the changes below seismic Reflector S30 are less pronounced (Fig. F41).

Further evidence of fluid flow is provided by downhole variations in chloride concentrations within Ursa Basin. Site U1322 exhibits a near-linear decrease in chlorinity from the seafloor to terminal depth (Fig. F41):

$$
y=3.7 \mathrm{e}^{3}-6.5 x ; R^{2}=0.68 .
$$

Initial concentrations are identical to the seawater concentration of $559 \mathrm{mM}$, increase rapidly to 578 $\mathrm{mM}$ at $15 \mathrm{mbsf}$, and then decrease to $542 \mathrm{mM}$ at the base of the hole. This gradual pore water freshening may indicate mixing between overlying seawater and fluids from the Blue Unit. Alternatively, dewatering of clay-rich lithologies during diagenesis may also produce freshening of pore waters. However, we suggest this latter possibility is less likely, as we did not observe a similar decrease in chlorinity with depths at Site U1324, which must have experienced more intense burial diagenesis as it was buried deeper (maximum drilling depth was 600 mbsf versus 238 mbsf at Site U1322).

\section{Preliminary interpretation of overpressure and hydrodynamics in Ursa Basin}

In the mudrocks above the Blue Unit in Ursa Basin, porosity declines rapidly in the uppermost $100 \mathrm{~m}$ and subsequently declines only slightly. Pressure predictions based on porosity suggest overpressures with a normalized overpressure ratio $\left(\lambda^{*}\right)>0.6$. Direct pressure measurements also record overpressures of $\lambda^{*}>0.5$. At equivalent depths, pressures (as recorded by both consolidation and direct measurements) are slightly greater to the east at Site U1322 where the overburden is thin than to the west at Site U1324 where the overburden is thick. The temperature gradient is significantly greater at Site U1322 $\left(26^{\circ} \mathrm{C} / \mathrm{km}\right)$ than to the west at Site $\mathrm{U} 1324\left(\sim 18^{\circ} \mathrm{C} /\right.$ $\mathrm{km})$. Sedimentation rates at Site U1324 were almost 3 times greater than those at Site U1322. A conceptual model that links these observations is that there is upward flow everywhere within the overburden above the Blue Unit; the flow rate is constant, reflecting a constant overpressure gradient, at each site. However, significant lateral flow within the Blue Unit must also be present to account for the similar overpressure gradient at the two locations (despite the threefold difference in sedimentation rate) and the elevated heat flow emanating from the Site U1322 location.

\section{Permeability architecture}

Sediments deposited in the last 70 k.y. in Ursa Basin can be divided into three successive depositional units: the Blue Unit, the Ursa and Southwest Pass Canyon channel-levee systems, and distal turbidite and hemipelagic deposits (Fig. F10).

The Blue Unit forms a regional permeable unit that is composed of interbedded thick sands (some $>50 \mathrm{~m}$ thick) and mudstone. Its base is the base of the deepest sand (Fig. F10); its top is the top of the first significant sand below seafloor outside of channel fill sands. In places, the thick Blue Unit sands are truncated by the Ursa channel system (Fig. F10).

The Ursa Canyon channel-levee system fill has highamplitude chaotic seismic reflections that most likely are permeable sands. However, the bounding 
deformation zone is dominated by mudstone of rotated channel-margin slides that sit within the Blue Unit beneath where the channel incised into the Blue Unit. Low-permeability mudstones cap the channel-levee systems and are thicker to the west (Site U1324) than to the east (Site U1322). Multiple MTDs are present throughout section, especially in the vicinity of Site U1322 (Fig. F33).

\section{Sedimentation rate: driving force for fluid flow}

Sedimentation drives overpressure. Late Pleistocene sedimentation rates in Ursa Basin were extremely rapid and have significant lateral variation (Fig. F32). On average, the sedimentation rate across the entire interval is 2.5 times greater at Site U1324 than at Site U1322 (10 versus $4 \mathrm{~mm} / \mathrm{y}$ ). This suggests that at the base of Site U1324 sedimentation rate exceeded $25 \mathrm{~m} / \mathrm{k} . \mathrm{y}$. and at Site U1322 it exceeded $16 \mathrm{~m} / \mathrm{k} . \mathrm{y}$.

\section{Pressure predicted from consolidation state above Blue Unit}

A striking feature of the three sites (U1322, U1323, and U1324) is that the porosities at equivalent depths are similar (Fig. F42). We predict pressure from porosity (see "Physical properties in BrazosTrinity IV and Ursa Basins") and find elevated pressures beneath $125 \mathrm{mbsf}$ at Site U1322 and beneath 150 mbsf at Site U1324 (Fig. F43). The overall overpressure ratio $\left(\lambda^{*}\right.$, [Equation 1]) is $\sim 0.5-0.6$ at each location.

\section{In situ pressure and temperature \\ Pressure}

We made multiple penetrometer measurements with the T2P and the DVTPP (Fig. F44). We have not processed these data and we have only posted the final pressures recorded at the end of the deployment. There is considerable scatter in these data (see "Challenges of measuring pressure"). At both locations, multiple measurements of in situ pressure record significant overpressures. Second, pressures between 100 and 250 mbsf are somewhat higher at Site U1322 than they are at Site U1324 (Fig. F44). This is intriguing because the porosity at these two sites is very similar at equivalent depths; thus, this difference is not predicted from the porosity-based pressure prediction. Deep at Site U1324, pore pressures rise to $\lambda^{*}$ between 0.5 and 0.6.

\section{Temperature}

The temperature gradient at Site U1324 is $18.4^{\circ} \mathrm{C} /$ $\mathrm{km}$, whereas it is $26.2^{\circ} \mathrm{C} / \mathrm{km}$ at Site U1322 (Fig. F45). These data were acquired by APCT tool, T2P, and DVTPP. The APCT tool measurements were corrected to estimate the actual temperature from the measured temperature; the DVTPP data and the T2P data have not been corrected. Thermal conductivities at the base of Site U1324 are $\sim 1.2 \mathrm{~W} /(\mathrm{m} \cdot \mathrm{K})$, whereas they are $\sim 1.15 \mathrm{~W} /(\mathrm{m} \cdot \mathrm{K})$ at Site $\mathrm{U} 1322$. If the heat flow is vertical and conductive, this implies a heat flow of $\sim 22 \mathrm{~mW} / \mathrm{m}^{2}$ at the base of Site U1324 versus $\sim 30 \mathrm{~mW} / \mathrm{m}^{2}$ at the base of Site U1322.

There are several possible explanations for the $\sim 1.4$ fold increase in heat flux at the base of Site U1322 relative to that at Site U1324. First, sedimentation is inversely correlated to heat flow (Wang and Davis, 1992). Thus, the increased thermal gradient at Site U1322 relative to Site U1324 may result from the fact that at Site U1322 the system is closer to thermal equilibrium, whereas at Site U1324 sedimentation was so rapid that it has outpaced the heat flow. A second possibility is that local variations in the proximity to salt bodies have significantly affected the local geothermal gradient. A final possible interpretation is that the heat flow entering the mudstone above the Blue Unit is greater at Site U1322 than at Site U1324 because there is lateral transfer of heat as described below.

\section{Conceptual hydrodynamic model}

Figure F46 illustrates our initial conceptual model for flow within Ursa Basin. After deposition of the Blue Unit, it was incised by the Ursa channel-levee system and then rapidly buried by mud. Sedimentation rates were extraordinarily rapid and the sedimentation rate at Site U1324 was almost three times that at Site U1322. One-dimensional flow modeling suggests that the overpressure and upward flow rate should be greater at Site U1324 than at U1322 because the sedimentation rate is so much higher at Site U1324. However, the presence of similar overpressure gradients within rocks of similar lithology (and presumably similar hydraulic conductivity) implies that the upward flux of water is approximately equal at each location. To equalize these pressure gradients, given the very different sedimentation rates, we infer some flow must occur laterally within the Blue Unit (Fig. F46). The temperature gradient at Site U1322 is significantly greater than at Site U1324, which implies a conductive heat flux that is 1.4 times greater at Site U1322 than at Site U1324 (Figs. F45, F46A, F46B). The elevated temperature gradient at Site U1322 may reflect lateral transfer of heat by advection within the Blue Unit (Fig. F46).

The overpressure encountered at the base of Site U1324 is significantly larger than at Site U1322 (3.1 versus $1.3 \mathrm{MPa}$ ) (Fig. F46). Early models suggested that the entire Blue Unit might be in hydrologic communication and that there would be a single 
overpressure encountered at both locations. Detailed analysis illustrates that the Blue Unit is composed of multiple sand bodies that have significant lateral extent (Fig. F46). These sands are truncated by the Ursa channel deformation zone, which has deformed the underlying Blue Unit. In the western location (Site U1324), the top of the Blue Unit has been eroded and only the deeper beds are present.

Based on pressure data analyzed here and more detailed regional seismic mapping, we interpret that only the basal sand within the Blue Unit has communicated laterally from Site U1324 to Site U1322. In this basal sand, flow is driven laterally toward Site U1322, underneath the Ursa channel-levee system. Within the Blue Unit at Site U1322, vertical flow will occur between the sand beds; however, there will be a large vertical pressure gradient within the shales between the sand beds. The impedance of these shale layers reduces the pressure from $\sim 3.1 \mathrm{MPa}$ at the base of the Blue Unit to $\sim 1.3 \mathrm{MPa}$ at the top of the Blue Unit (Fig. F46). These observations illustrate the critical importance of being able to sample the pressure field within the Blue Unit in order to fully understand this hydrodynamic system.

\section{Overview of expedition achievements and preliminary scientific assessment}

\section{Original objectives}

We address the expedition achievements in light of the six original scientific objectives of Expedition 308 (see "Introduction").

\section{Document how pressure, stress, and geology couple to control fluid migration on passive margins.}

Our goal was to establish the vertical and lateral variation in pressure and rock properties above the Blue Unit to test the flow-focusing model and image the flow system within the mudstone capping the Blue Unit.

We established the overpressure profile as a function of depth at two key locations in Ursa Basin: Sites U1322 and U1324. These measurements were difficult and we had a high failure rate (see "Challenges of measuring pressure"); however, ultimately we acquired enough data to constrain the overpressure field above the Blue Unit. To our knowledge, this is the first time in DSDP/ODP/IODP history that the spatial variation of the pressure field has been documented at this resolution. Previous deployments of the DVTPP generally yielded only single measure- ments in boreholes. We also acquired an extraordinary temperature data set that documented striking differences in temperature gradient between Sites U1322 and U1324 (Fig. F44). We also took an extensive amount of whole core for geotechnical analysis. Geotechnical experiments on these cores will further constrain the in situ pressure through analysis of the preconsolidation stresses. Modeling of the DVTPP and T2P pressure dissipation profiles will also further constrain the pressure field.

Our initial observations suggest both lateral and vertical flow are present within the Blue Unit. A fundamental result is that the pressure gradient at the two sites (U1322 and U1324) are similar despite the large difference in sedimentation rate at these locations. We infer that the hydrodynamic flow field within the Blue Unit is more complicated than originally envisioned (Fig. F46) (see "Preliminary interpretation of overpressure and hydrodynamics in Ursa Basin"). Ultimately, to understand the flow field within and around the Blue Unit, it will be necessary to sample the pressures within the Blue Unit sands.

We acquired whole core at Sites U1322 and U1324, LWD/MWD logs at Site U1322, U1323, and U1324, and wireline logs at Site U1324. These data will be used to accurately constrain the variations in rock properties across Ursa Basin. All objectives were met at Sites U1322 and U1324. Because we encountered shallow-water flow at Site U1323, we were unable to core at this location. LWD/MWD, wireline logging, and coring proceeded with extraordinary efficiency despite the fact we were drilling in zones of significant overpressure.

\section{Establish reference properties at Brazos- Trinity Basin IV.}

We wanted to establish reference logging and core properties where overpressure is not present at a range of effective stresses in the Brazos-Trinity Basin. Coring and logging were successful at the BrazosTrinity Basin IV locations. However, only a limited number of pressures were measured due to early struggles with the DVTPP and T2P (see "Challenges of measuring pressure"). An intriguing result is that the mudstones beneath Brazos-Trinity Basin IV (Site U1319) may be overpressured (Fig. F36). If Site U1319 is overpressured, then Sites U1319 and U1320 will provide important examples of a normally pressured location (Site U1319) and overpressured location (Site U1320) in the same location.

\section{Illuminate the controls on slope stability.}

We wanted to determine pore pressure, rock properties, and overburden stress to predict the potential 
for MTDs and estimate the conditions that drove previous MTDs. We collected a beautiful suite of data (whole core for geotechnical analysis, in situ pressures, and logs) across the bases of MTDs. A striking result is the high degree of consolidation that is present within MTDs (Fig. F37). A major component of the shore-based science will study the geometry, physical properties, timing, and pressures associated with these MTDs.

\section{Understand timing of sedimentation and mass transport deposits.}

We wanted to establish the age of sediments in Brazos-Trinity Basin IV and Ursa Basin. Our preliminary results (Figs. F28, F32) suggest that the Brazos-Trinity Basin IV sediments span MIS 6 to present, whereas the Ursa mudstones are $<70 \mathrm{ka}$. In Brazos-Trinity Basin IV, MTDs, turbidite deposition, and sea level change were tightly linked. Dramatically high sedimentation rates were documented in Ursa Basin. Shore-based research will further constrain the chronostratigraphy of these systems.

\section{Establish geotechnical and petrophysical properties of shallow sediments.}

We wanted to break new ground in understanding geotechnical and petrophysical properties of shallow sediments (0-1000 mbsf). To support and complement core observations and laboratory measurements, we derived a complete logging suite, in situ measurements of pressure, and whole-core geotechnical samples. We will use these data to understand the compaction process near the seafloor and the evolution of overpressure during sedimentation. The ultimate scientific impact of acquiring these data will unfold in the years ahead. However, the Expedition 308 data set represents a linked data set that has the potential to provide unparalleled insight into mudstone permeability and rheology.

\section{Provide an extraordinary data set to observe ponded and channelized turbidite systems.}

Expedition 308 sampled the ponded turbidite system in Brazos-Trinity Basin IV and the channelized systems present in Ursa Basin. These data are of great interest to both academic and industry researchers and will be deeply studied in postcruise research.

\section{Additional achievements}

Expedition 308 was the first time where downhole pressure and lithology were monitored in real time (MWD) and it was the first time that weighted mud was used as a tool to drill through overpressured re- gimes (see "Challenges of drilling in overpressured basins"). Real-time monitoring allowed us to observe shallow-water flow and to respond to this incident by raising the mud weight in order to hold back flow into the borehole. At both Sites U1323 and U1324 we showed that weighted mud and real-time monitoring can be used to safely drill and complete operations. Future expeditions in a variety of settings might benefit from the planned use of weighted mud to stabilize the borehole.

We expect research on the cores and data generated during Expedition 308 to break new ground, especially in the field of geotechnical and hydrogeological analysis of continental slope sediment successions, be it at passive or active continental margins. Despite initial setbacks, we have shown that programs of in situ measurement of pore pressure in fine-grained sediments can be done with overall success. We have demonstrated that drilling into overpressured formations with riserless technology can be managed using heavy mud, fluid flow into the borehole can be controlled, and operations can be safely concluded without risk to the seafloor environment.

\section{References}

Badalini, G., Kneller, B., and Winker, C.D., 2000. Architecture and processes in the late Pleistocene Brazos-Trinity turbidite system, Gulf of Mexico continental slope. Deep-Water Reservoirs of the World: Proc. GCSSEPM 20th Annu. Res. Conf., 16-34.

Beaubouef, R.T., Abreu, V., and Van Wagoner, J.C., 2003. Basin 4 of the Brazos-Trinity slope system, western Gulf of Mexico: the terminal portion of a late Pleistocene lowstand system tract: shelf margin deltas and linked down slope petroleum systems: global significance and future exploration potential. Proc. GCSSEPM 23rd Annu. Res. Conf., 45-66.

Beaubouef, R.T., and Friedmann, S.J., 2000. High resolution seismic/sequence stratigraphic framework for the evolution of Pleistocene intra slope basins, western Gulf of Mexico: depositional models and reservoir analogs. Deep-Water Reservoirs of the World: Proc. GCSSEPM 20th Annu. Res. Conf., 40-60.

Bethke, C.M., 1986. Inverse hydrologic analysis of the distribution and origin of Gulf Coast-type geopressured zones. J. Geophys. Res., 91(B6):6535-6545.

Boehm, A., and Moore, J.C., 2002. Fluidized sandstone intrusions as an indicator of paleostress orientation, Santa Cruz, California. Geofluids, 2(2):147-161. doi:10.1046/j.1468-8123.2002.00026.x

Bredehoeft, J.D., and Hanshaw, B.B., 1968. On the maintenance of anomalous fluid pressures: 1 . Thick sedimentary sequences. Geol. Soc. Am. Bull., 79:1097-1106.

Bryant, W.R., Bryant, J.R., Feeley, M.H., and Simmons, G.R., 1990. Physiographic and bathymetric characteris- 
tics of the continental slope, northwest Gulf of Mexico. Geo-Mar. Lett., 10:182-199.

Davies, R., Bell, B.R., Cartwright, J.A., and Shoulders, S., 2002. Three-dimensional seismic imaging of Paleogene dike-fed submarine volcanoes from the northeast Atlantic margin. Geology, 30:223-226. doi:10.1130/00917613(2002)030<0223:TDSIOP>2.0.CO;2

D’Hondt, S.L., Jørgensen, B.B., Miller, D.J., et al., 2003. Proc. ODP, Init. Repts., 201 [CD-ROM]. Available from: Ocean Drilling Program, Texas A\&M University, College Station TX 77845-9547, USA. [HTML]

Drexler, J.W., Rose, W.I., Jr., Sparks, R.S.J., and Ledbetter, M.T., 1980. The Los Chocoyos ash, Gautemala: a major stratigraphic marker in middle America and three ocean basins. Quat. Res., 13:327-345. doi:10.1016/00335894(80)90061-7

Dugan, B., and Flemings, P.B., 2000. Overpressure and fluid flow in the New Jersey Continental Slope: implications for slope failure and cold seeps. Science, 289:288291. doi:10.1126/science.289.5477.288

Eaton, L.F., 1999. Drilling through deepwater shallow water flow zones at Ursa. Proc.-SPE/IADC Middle East Drill. Conf., 153-164.

Fertl, W.H., 1976. Abnormal Formation Pressures: Implications to Exploration, Drilling, and Production of Oil and Gas Resources: Amsterdam (Elsevier).

Flemings, P.B., Stump, B.B., Finkbeiner, T., and Zoback, M., 2002. Flow focusing in overpressured sandstones: theory, observations, and applications. Am. J. Sci., 302:827855.

Gardiner, W.B., 1986. Seismic stratigraphy and salt tectonics of the East Breaks region, Gulf of Mexico [M.A. thesis]. Texas A\&M Univ., College Station.

Gibson, R.E., 1958. The progress of consolidation in a clay layer increasing in thickness with time. Geotechnique, 8:171-182.

Koppula, S.D., and Morgenstern, N.R., 1982. On the consolidation of sedimenting clays. Can. Geotech. J., 19:260-268.

Lambe, T.W., and Whitman, R.V., 1969. Soil Mechanics. Massachusetts Institute of Technology, 553.

Mallarino, G., Droxler, A.W., Beaubouef, R.T., Abreu, V., and Labeyrie, L., in press. Sea level influence on the nature and timing of a mini-basin sedimentary fill (northwestern slope of the Gulf of Mexico). AAPG Bull.

Moore, G.F., Taira, A., Bangs, N.L., Kuramoto, S., Shipley, T.H., Alex, C.M., Gulick, S.S., Hills, D.J., Ike, T., Ito, S., Leslie, S.C., McCutcheon, A.J., Mochizuki, K., Morita, S., Nakamura, Y., Park, J.-O., Taylor, B.L., Toyama, G., Yagi, H., and Zhao, Z., 2001. Data report: Structural setting of the Leg 190 Muroto Transect. In Moore, G.F., Taira, A., Klaus, A., et al., Proc. ODP, Init. Repts., 190, 1-14 [CD-ROM]. Available from: Ocean Drilling Program, Texas A\&M University, College Station TX 77845-9547, USA. [HTML]

Osborne, M.J., and Swarbrick, R.E., 1997. Mechanisms for generating overpressures in sedimentary basins: a reevaluation. AAPG Bull., 81:1023-1041.

Ostermeier, R.M., Pelletier, J.H., Winker, C.D., Nicholson, J.W., Rambow, F.H., and Cowan, K.M., 2000. Dealing with shallow-water flow in the deepwater Gulf of Mexico. Proc. Offshore Tech. Conf., 32(1):75-86.

Ostermeier, R.M., Pelletier, J.H., Winker, C.D., and Nicholson, J.W., 2001. Trends in shallow sediment pore pressures. Proc.-SPE/IADC Drill. Conf., 1-11.

Pelletier, J.H., Ostermeier, R.M., Winker, C.D., Nicholson, J.W., and Rambow, F.H., 1999. Shallow water flow sands in the deepwater Gulf of Mexico: some recent Shell experience [International Forum on Shallow Water Flows Conference, League City, TX, 6-9 Oct., 1999].

Pirmez, C., Beaubouef, R.T., Friedmann, S.J., and Mohrig, D.C., 2000. Equilibrium profile and base level in submarine channels: examples from late Pleistocene systems and implications for the architecture of deepwater reservoirs. In Wimer, P., Slatt, R.M., Coleman, J., Rosen, N.C., Nelson, H., Bouma, A.H., Styzen, M.J., and Lawrence, D.T. (Eds.), Deep-Water Reservoirs of the World: Proc. GCSSEPM 20th Annu. Res. Conf., 782-805.

Pratson, L.F., and Ryan, W.B.F., 1994. Pliocene to Recent infilling and subsidence of intraslope basins offshore Louisiana. AAPG Bull., 78:1483-1506.

Pulham, A.J., 1993. Variations in slope deposition, Pliocene-Pleistocene, offshore Louisiana, northeast Gulf of Mexico. In Posamentier, H., and Weimer, P. (Eds.), Siliclastic Sequence Stratigraphy: Recent Developments and Applications. AAPG Mem., 58:199-233.

Rubey, W.W., and Hubbert, M.K., 1959. Role of fluid pressure in mechanics of overthrust faulting, Part 2. Overthrust belt in geosynclinal area of western Wyoming in light of fluid-pressure hypothesis. Geol. Soc. Am. Bull., 70:167-205.

Satterfield, W.M., 1988. Late Quaternary sedimentology and evolution of the continental slope (long $94^{\circ}-95^{\circ}$ ), northwest Gulf of Mexico [M.S. thesis]. Univ. Texas, Austin.

Satterfield, W.M., and Behrens, E.W., 1990. A late Quaternary canyon channel system, northwest Gulf of Mexico continental slope. Mar. Geol., 92(1):51-67.

Schulz, H.D., 2000. Quantification of early diagenesis; dissolved constituents in marine pore water. In Schulz, H., and Zabel, M. (Eds.), Marine Geochemistry: Berlin (Springer-Verlag), 85-128.

Seldon, B., and Flemings, P.B., 2005. Reservoir pressure and seafloor venting: Predicting trap integrity in a deepwater turbidite reservoir, AAPG Bull., 89(2):193-209.

Swarbrick, R.E., and Osborne, M.J., 1996. The nature and diversity of pressure transition zones. Pet. Geosci., 2:111-115.

Tréhu A.M., Bohrmann, G., Rack, F.R., Torres, M.E., et al., 2003. Proc. ODP, Init. Repts., 204 [CD-ROM]. Available from: Ocean Drilling Program, Texas A\&M University, College Station TX 77845-9547, USA. [HTML]

Wang, K., and Davis, E.E., 1992. Thermal effects of marine sedimentation in hydrothermally active areas. Geophys. J. Int., 110:70-78.

Winker, C.D., 1996. High-resolution seismic stratigraphy of a late Pleistocene submarine fan ponded by salt-withdrawal minibasins on the Gulf of Mexico continental 
slope. Proc. 3rd Annu. Offshore Technol. Conf., 28(1):619628.

Winker, C.D., and Booth, J.R., 2000. Sedimentary dynamics of the salt-dominated continental slope, Gulf of Mexico: integration of observations from the seafloor, near-surface, and deep subsurface. Deep-Water Reservoirs of the World: Proc. GCSSEPM 20th Annu. Res. Conf., 10591086.
Worrall, D.M., and Snelson, S., 1989. Evolution of the northern Gulf of Mexico, with emphasis on Cenozoic growth faulting and the role of salt. In Bally, A.W., and Paler, A.R. (Eds.), The Geology of North America-An Overview (Vol. A): Boulder, CO (Geol. Soc. Am.), 97-137.

Publication: 8 July 2006

MS 308-101 
Figure F1. A. Overpressure results when sedimentation occurs more rapidly than fluids can be expelled by compaction. B. Overpressure $\left(P^{\star}\right)$ is pressure that is greater than the hydrostatic pressure. Vertical effective stress (VES) is the difference between the lithostatic stress and the pore pressure. C. Overpressure causes low effective stresses, which are recorded by an "undercompacted" porosity profile. A suite of models describes how overpressure is generated during rapid deposition (Bethke, 1986; Bredehoeft and Hanshaw, 1968; Gibson, 1958; Koppula and Morgenstern, 1982; Osborne and Swarbrick, 1997; Swarbrick and Osborne, 1996).
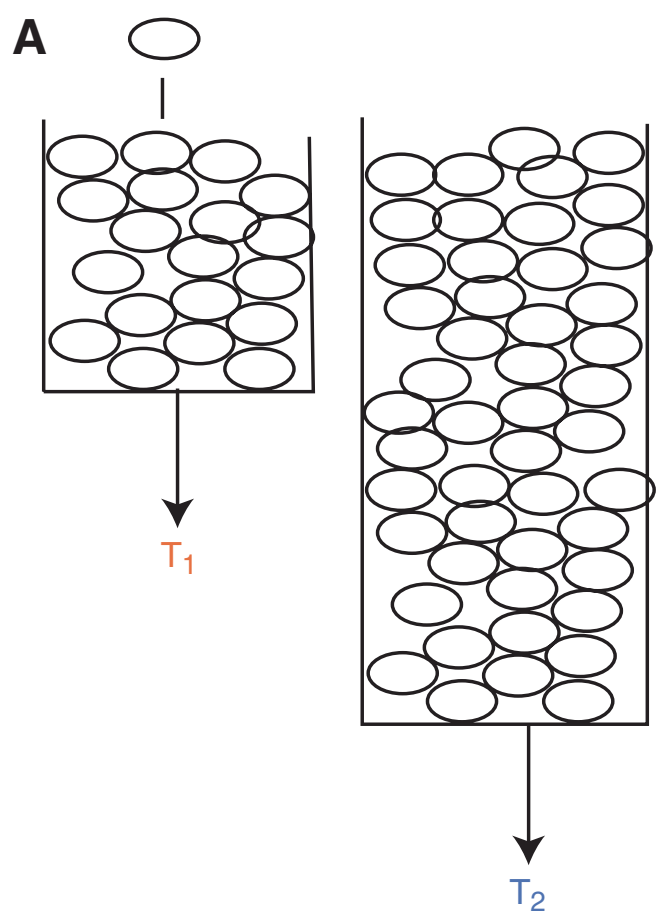

B

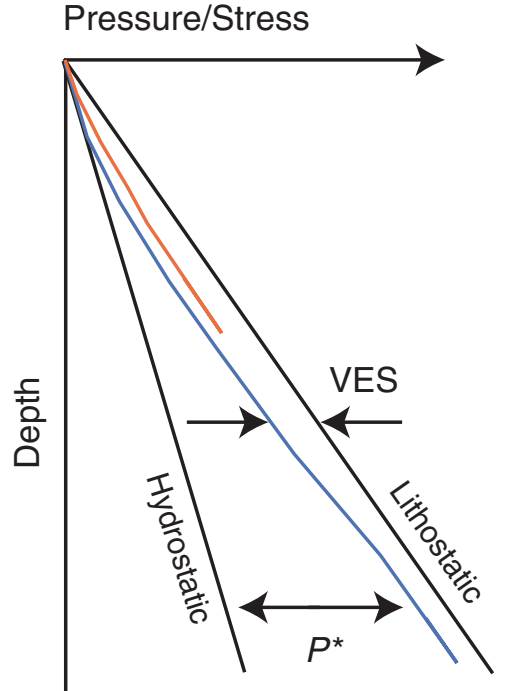

C

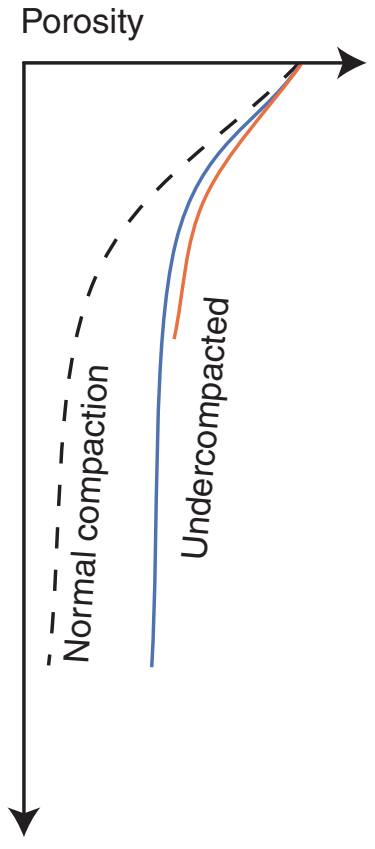


Figure F2. Flow-focusing model. A. Low-permeability sediments are rapidly deposited on a high-permeability aquifer (outlined in white). The sedimentation rate decreases from left to right, resulting in the final wedgeshaped geometry. Rapid sedimentation generates overpressures $\left(P^{*}\right.$; color contours) that are greatest on the left (red). Flow is driven laterally (left to right) along the aquifer and expelled at the toe of the slope where the aquifer ends (white arrows). The vertical effective stress (black contours) is lowest on the right. B. Predicted overpressure profiles where overburden is thick (Site U1324) and thin (Site U1322). (1) Overpressure at Site U1324 is greater than at Site U1322 for equivalent depths. (2) The vertical effective stress $\left(\sigma_{v}{ }^{\prime}\right)$ is much lower at Site U1322 than at Site U1324. (3) Porosities are much lower at Site U1322 than at Site U1324 for equivalent depths. (4) Pore pressures $(P)$ equal the overburden stress $\left(\sigma_{v}\right)$ at Site U1322. (5) Infinite slope analyses (FS; relates the failure-driving stress to the available shear strength for shallow failures) predict unstable conditions $(\mathrm{FS}<1)$ for Site U1322. (6) Simulated vertical fluid velocity is higher at Site U1322 than at Site U1324. At Site U1324, we predict upward flow for most of the section but downward flow (velocity $<0$ ) just above the aquifer. Model parameters: low permeability mudstone $k_{\mathrm{v}}<5 \times 10^{-8} \mathrm{~m}^{2}$ and $k_{\mathrm{h}}<5 \times 10^{-16} \mathrm{~m}^{2}$; aquifer permeability $k_{\mathrm{h}}$ $=k_{\mathrm{v}} 5 \times 10^{-14} \mathrm{~m}^{2} ;$ maximum sedimentation rate $=3.5 \mathrm{~mm} / \mathrm{y}$; minimum sedimentation rate $=0.8 \mathrm{~mm} / \mathrm{y}$.
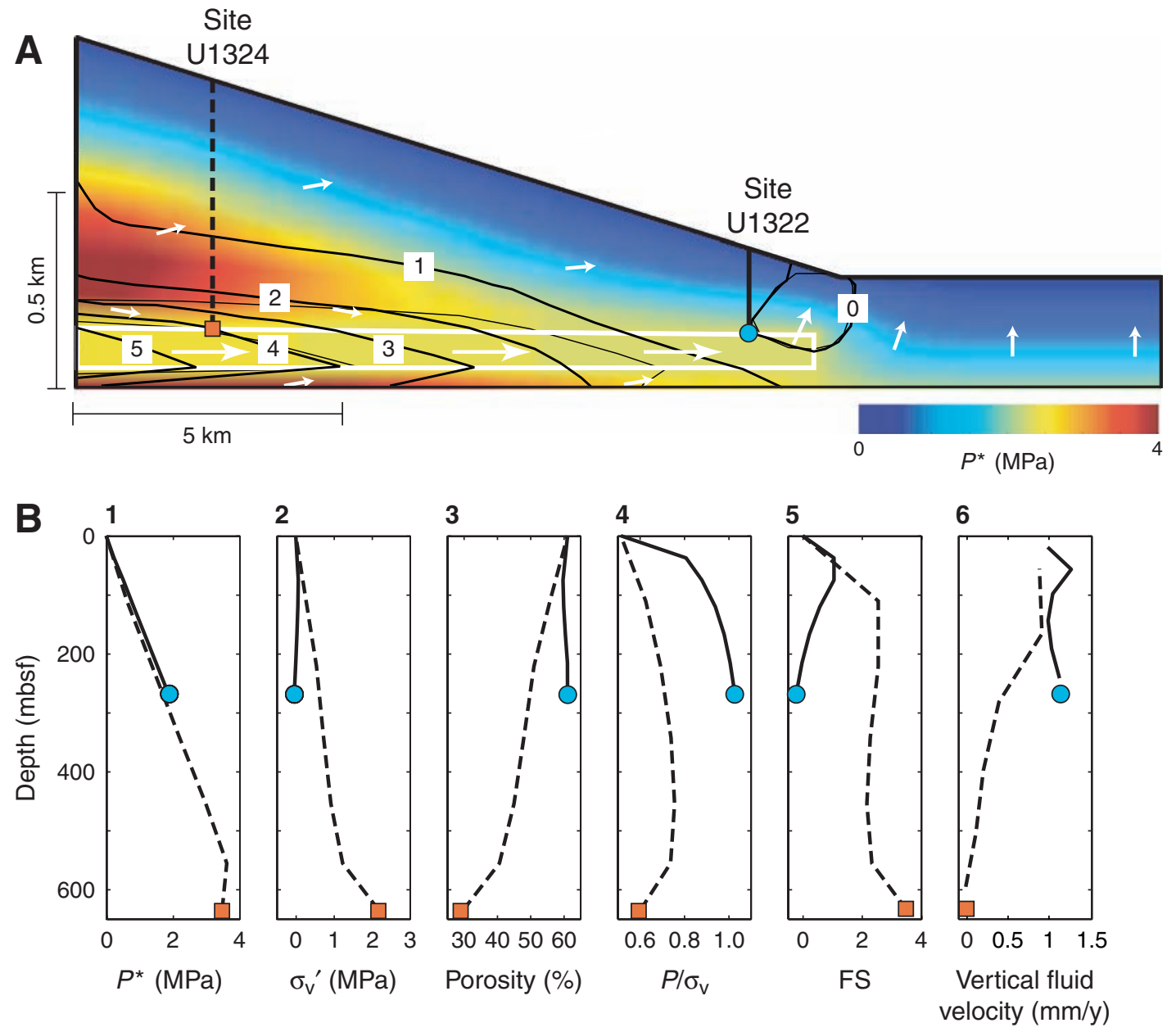
Figure F3. Flow-focusing drives (A) slope instability and (B) the migration of fluids. $\sigma_{\mathrm{v}}=$ overburden stress, $\sigma_{\mathrm{hmin}}=$ minimum horizontal stress, $\mathrm{P}_{\mathrm{o}}=$ oil pressure.
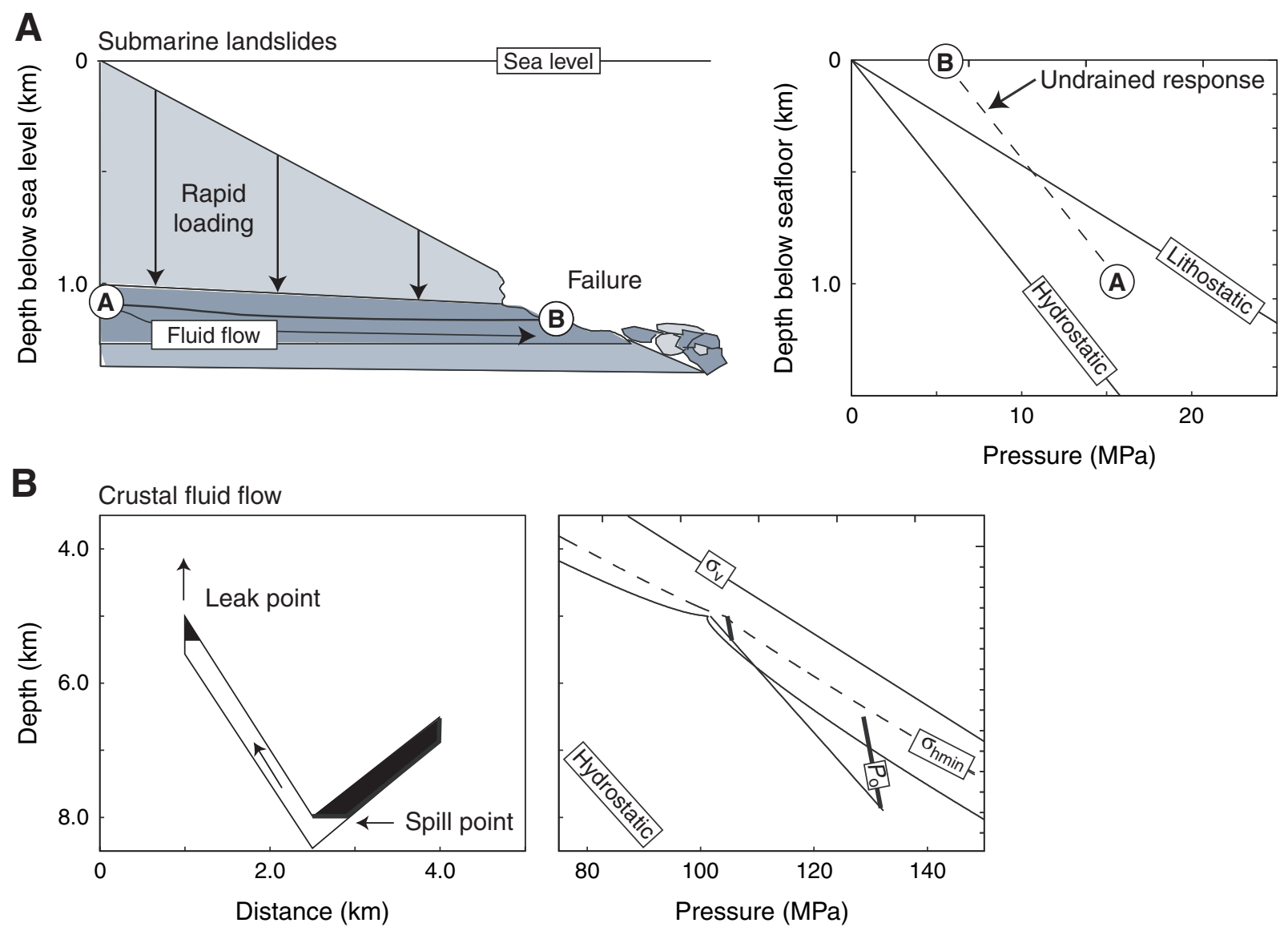
Figure F4. Bathymetric image of the continental slope of the Gulf of Mexico. Proposed drilling was in the Brazos-Trinity region and the Ursa region.

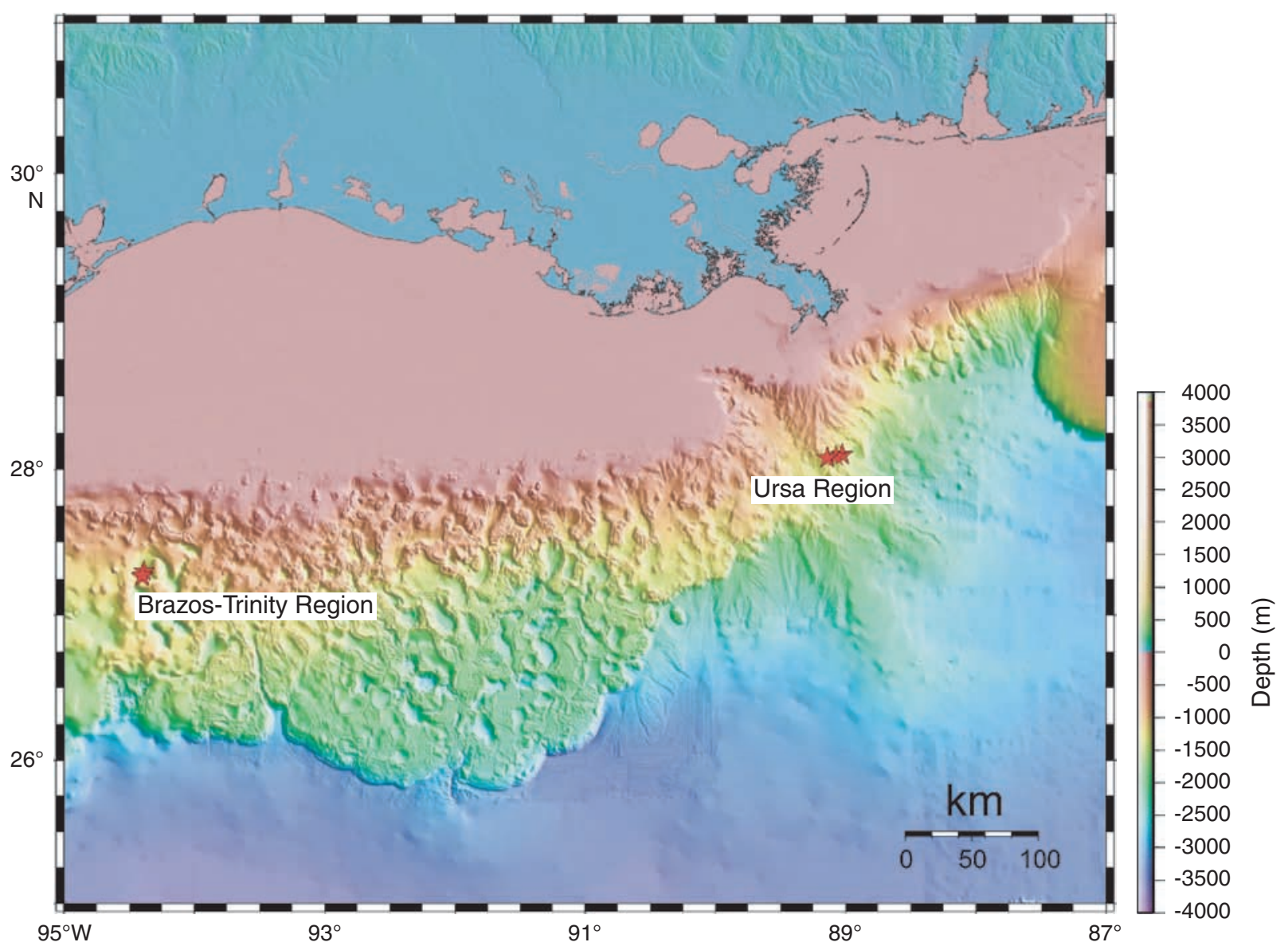


Figure F5. Bathymetric chart of Brazos-Trinity Basin IV showing locations for dip seismic Line 3020 and the three sites drilled during Expedition 308. Depth below sea level contours are at $10 \mathrm{~m}$ intervals. Artificial sun illumination from the northwest. Bathymetric information adapted from report Number 3060-TAMU-GOM.

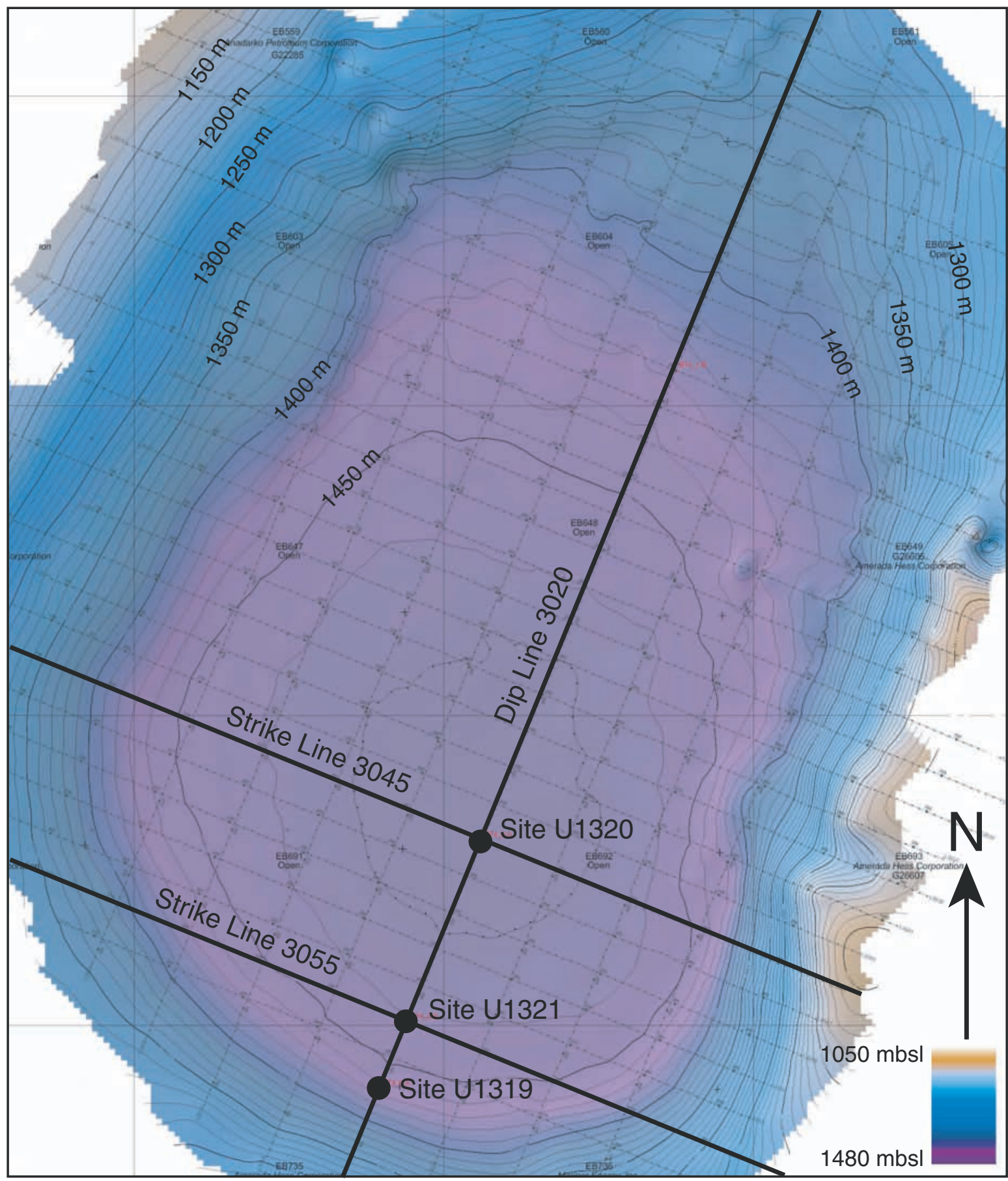


Figure F6. Dip seismic Section 3020 (shown in Fig. F5). Specific sites are located at the cross-tie with strike Line 3045 (Site U1320), strike Line 3055 (Site U1321), and at the southern limit of this line (Site U1319). Primary sites for Brazos-Trinity include Site U1320 and U1319. Site U1321 was a secondary site in original proposal. $\mathrm{SF}=$ seafloor.

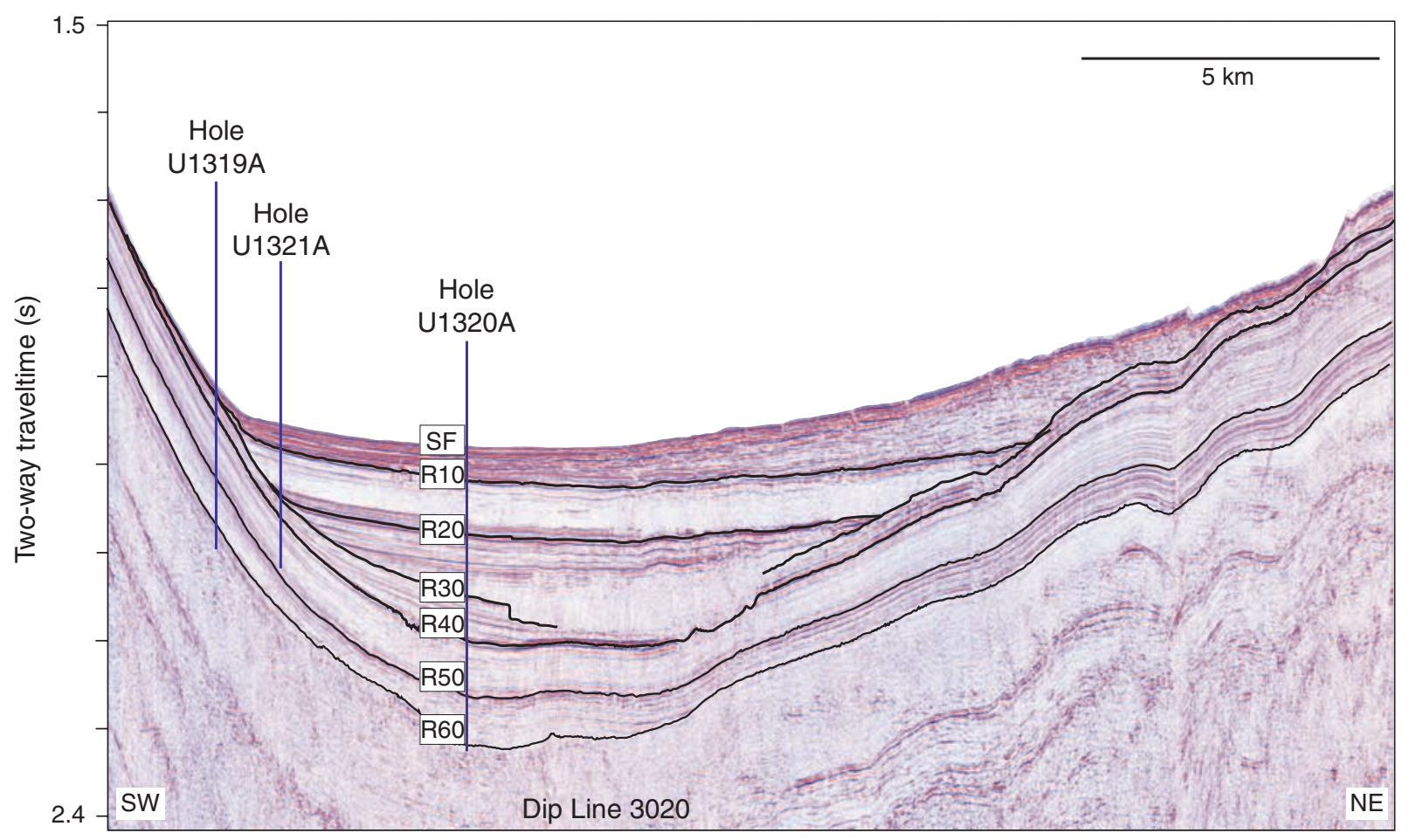


Figure F7. Strike seismic Line 3045. Primary Site U1320 is located at the intersection of Lines 3020 and 3045.

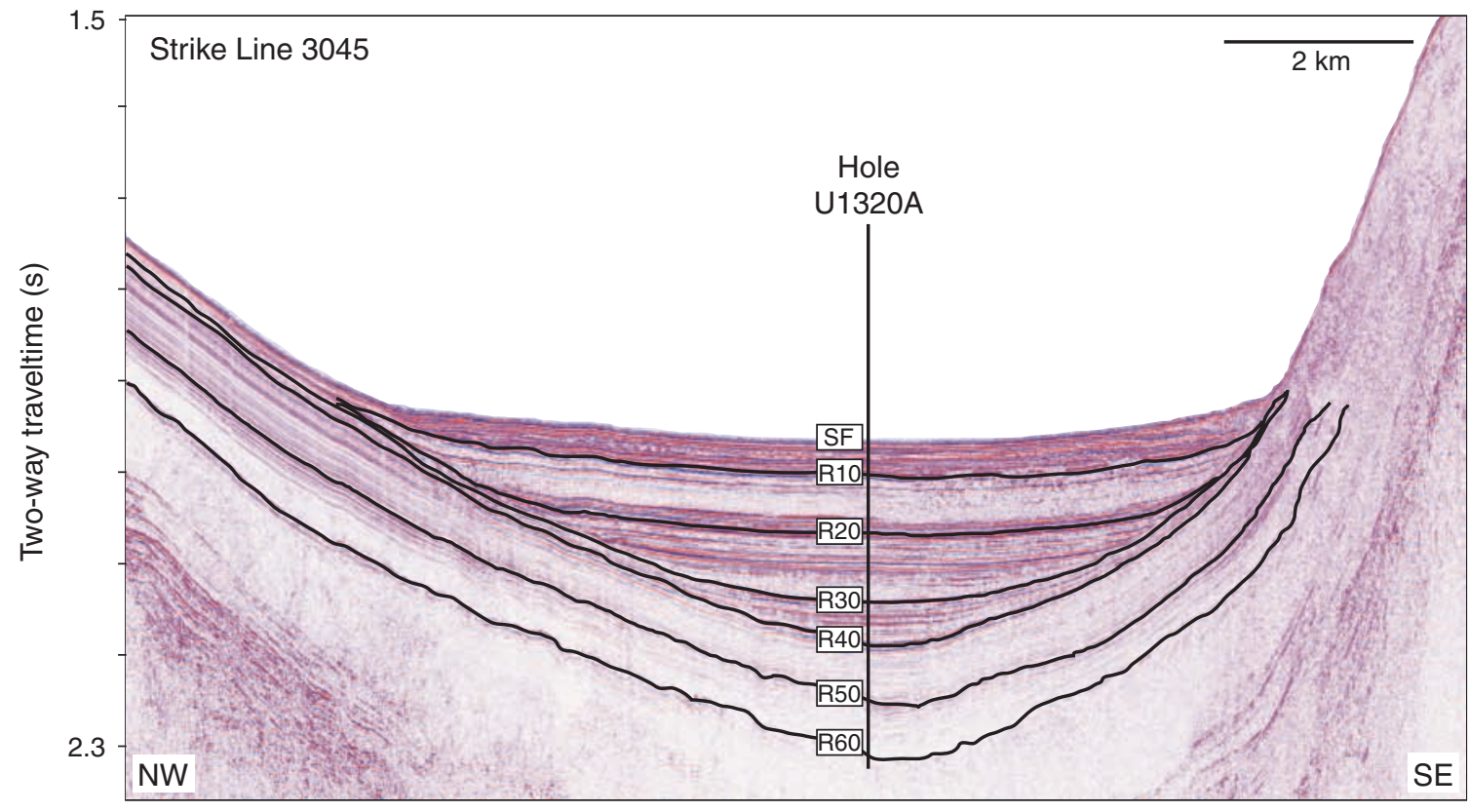


Figure F8. Bathymetric image of the Ursa region illustrating the location of Sites U1322, U1323, and U1324.

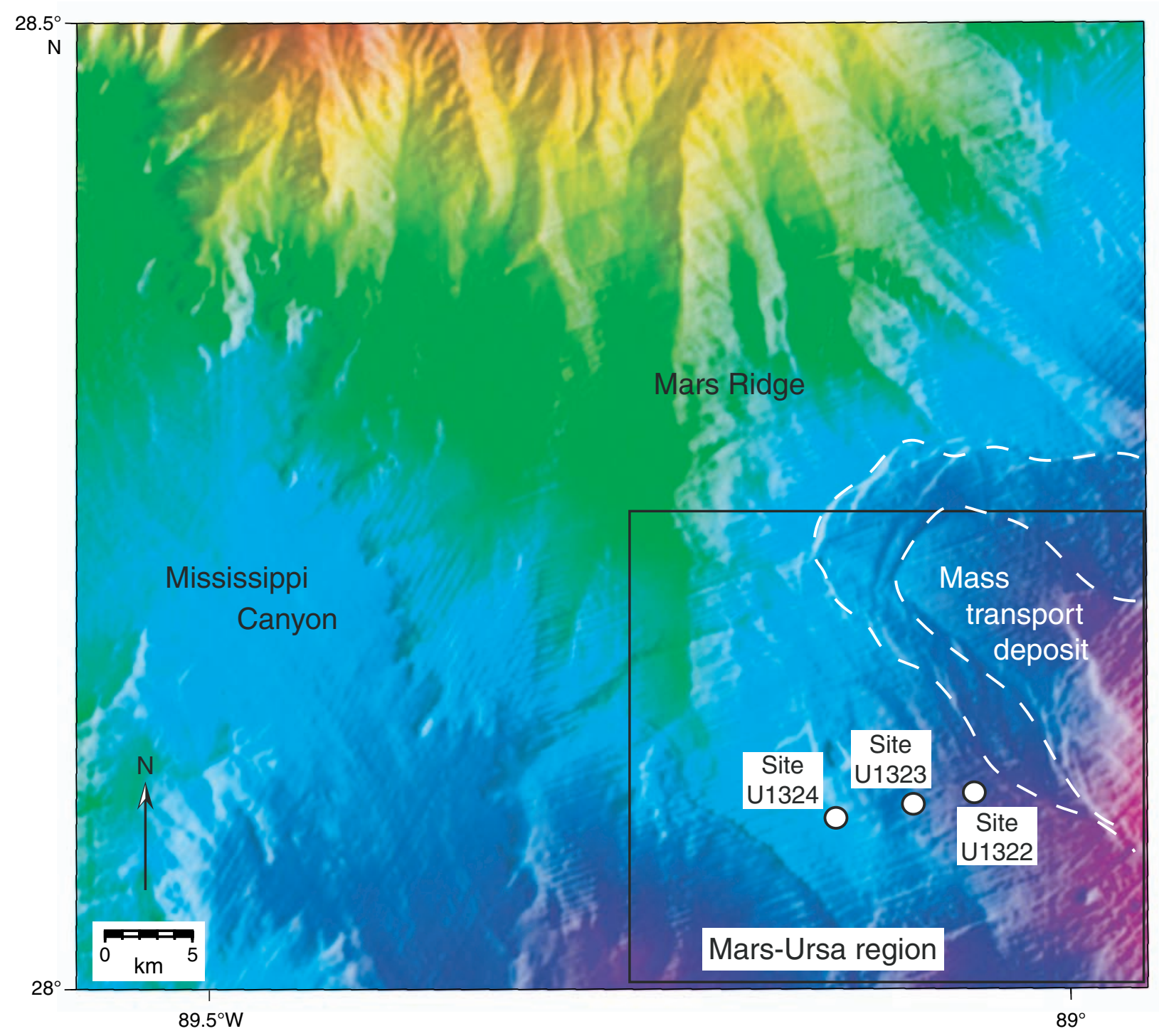


Figure F9. Basemap of seismic cross-section A-A'.

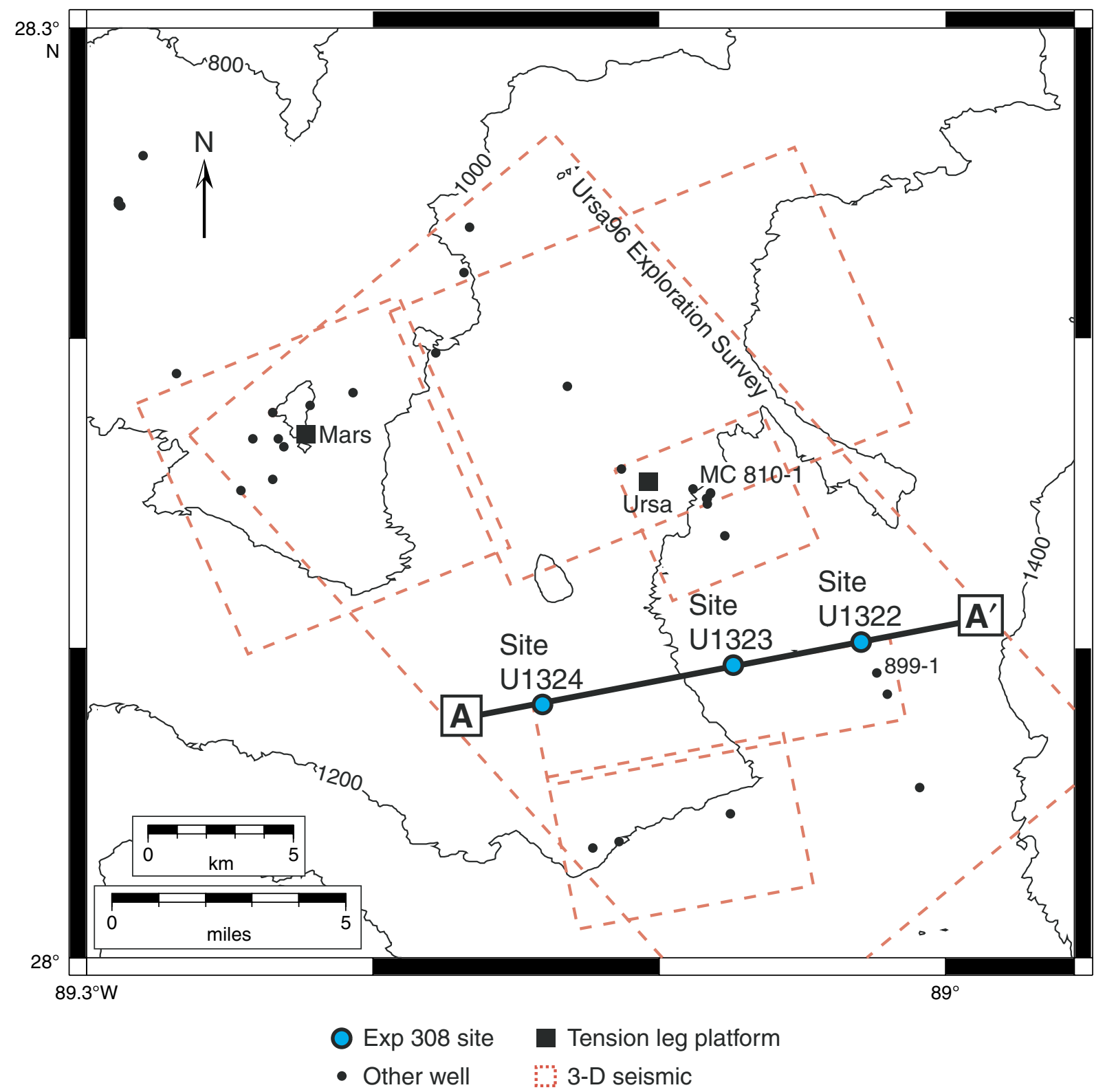


Figure F10. Gamma ray (NGR) and resistivity logs, core and log porosities, and in situ pressures at M.C. 810 Ursa geotechnical well 1. The Blue Unit (light gray) lies between 300 and 550 mbsf and is composed of interbedded sandstone and mudstone layers. Core porosity $\left(\phi_{\text {core }}\right)$ declines rapidly with depth to 200 mbsf and thereafter is constant. Overpressure $\left(P^{*}=P-P_{\mathrm{h}}\right)$ is plotted; thus the vertical axis is hydrostatic pressure $\left(P_{\mathrm{h}}\right)$ and the right boundary of the plot is the reduced lithostatic pressure $\left(\sigma_{v}{ }^{*}=\sigma_{v}-P_{\mathrm{h}}\right)$. Circles $=$ piezoprobe pressures, triangles $=$ preconsolidation pressures from uniaxial consolidation tests of core, stars $=$ pressure measurements inferred from pressure while driling (PWD) in the Blue Unit. Ostermeier et al. (2000) and Eaton (1999) further describe these data.

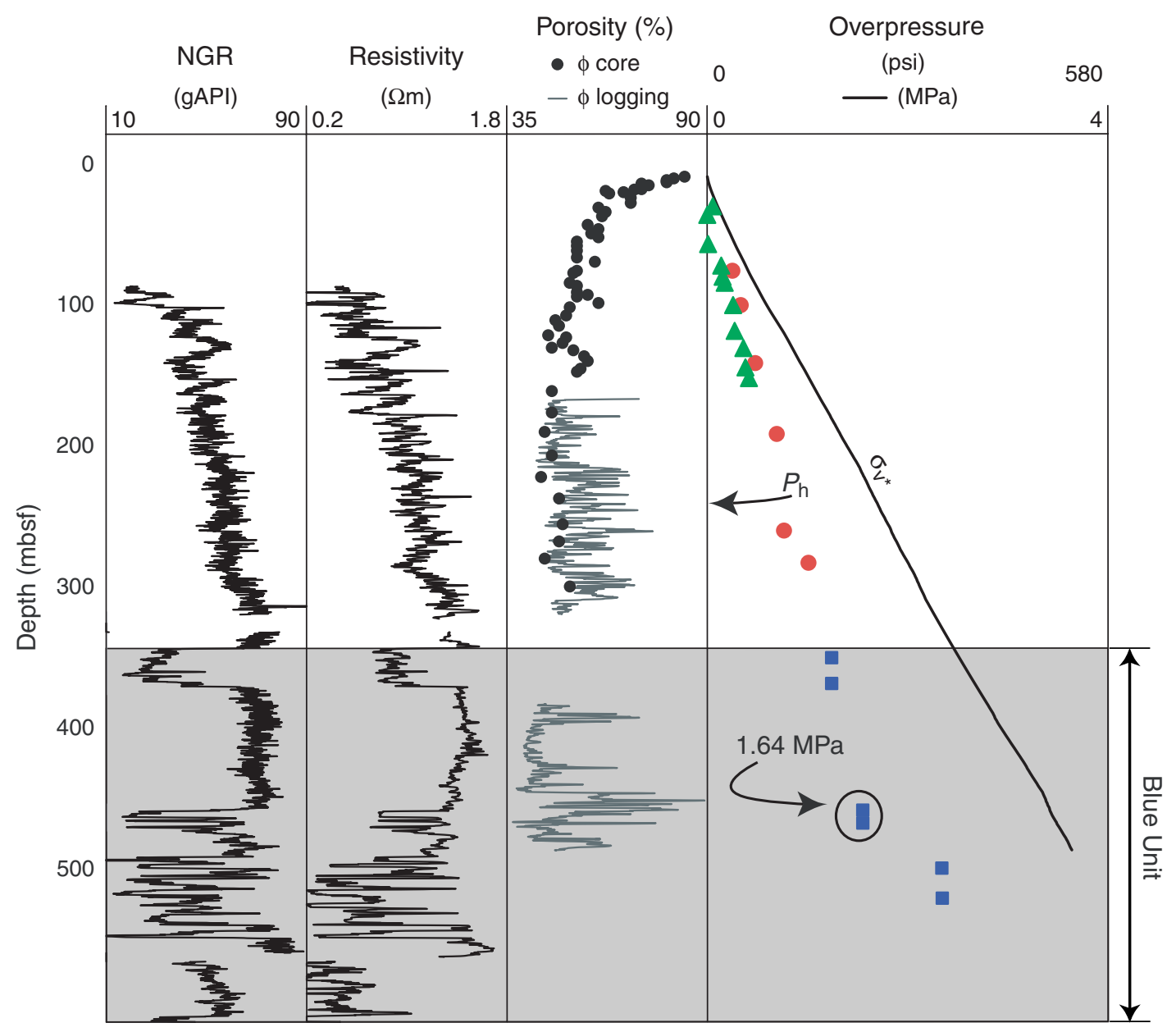


Figure F11. A. Seismic cross-section $A-A^{\prime}$. B. Interpreted cross-section $A-A^{\prime}$. The sand-prone Blue Unit is incised by a channel-levee complex and then overlain by a thick and heavily slumped hemipelagic mudstone wedge that thickens to the west (left). The Blue Unit sands are correlated to a distinct seismic facies. MTD = mass transport deposit.
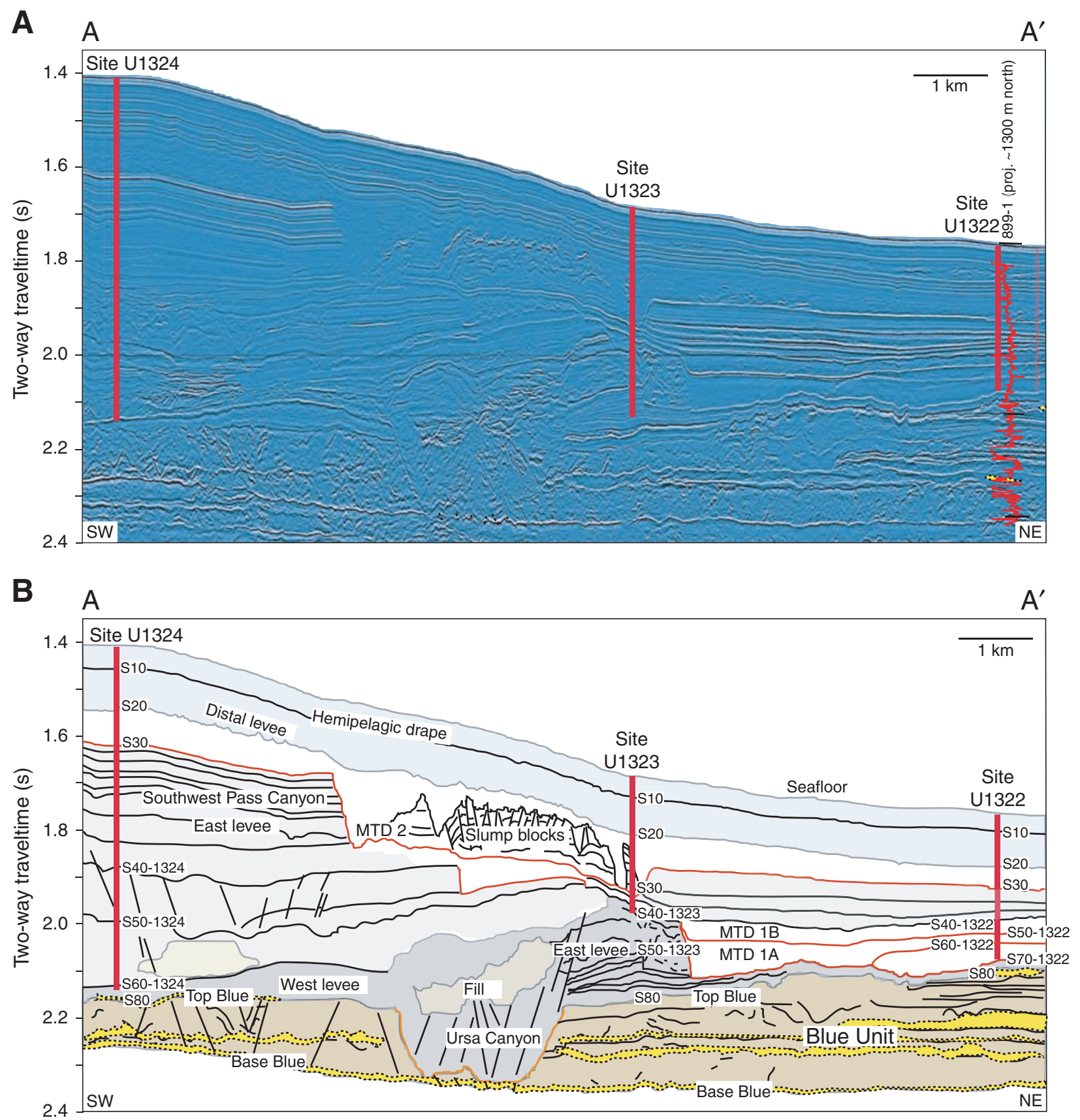
Figure F12. The T2P penetrometer was developed by MIT, Pennsylvania State University, and IODP-TAMU. It is designed to measure pore pressure and hydraulic conductivity in mudstones. The plot illustrates the dissipation at both the tip and the shaft after penetration in a December 2004 land deployment in Boston Blue Clay in Newburyport, Massachusetts (USA). Excess pore pressure ratio $=\left(u-u_{\mathrm{h}}\right) /\left(u_{\mathrm{i}}-u_{\mathrm{h}}\right) . u=$ pore pressure, $u_{\mathrm{h}}=$ hydrostatic pressure, $u_{\mathrm{i}}=$ peak insertion pressure.

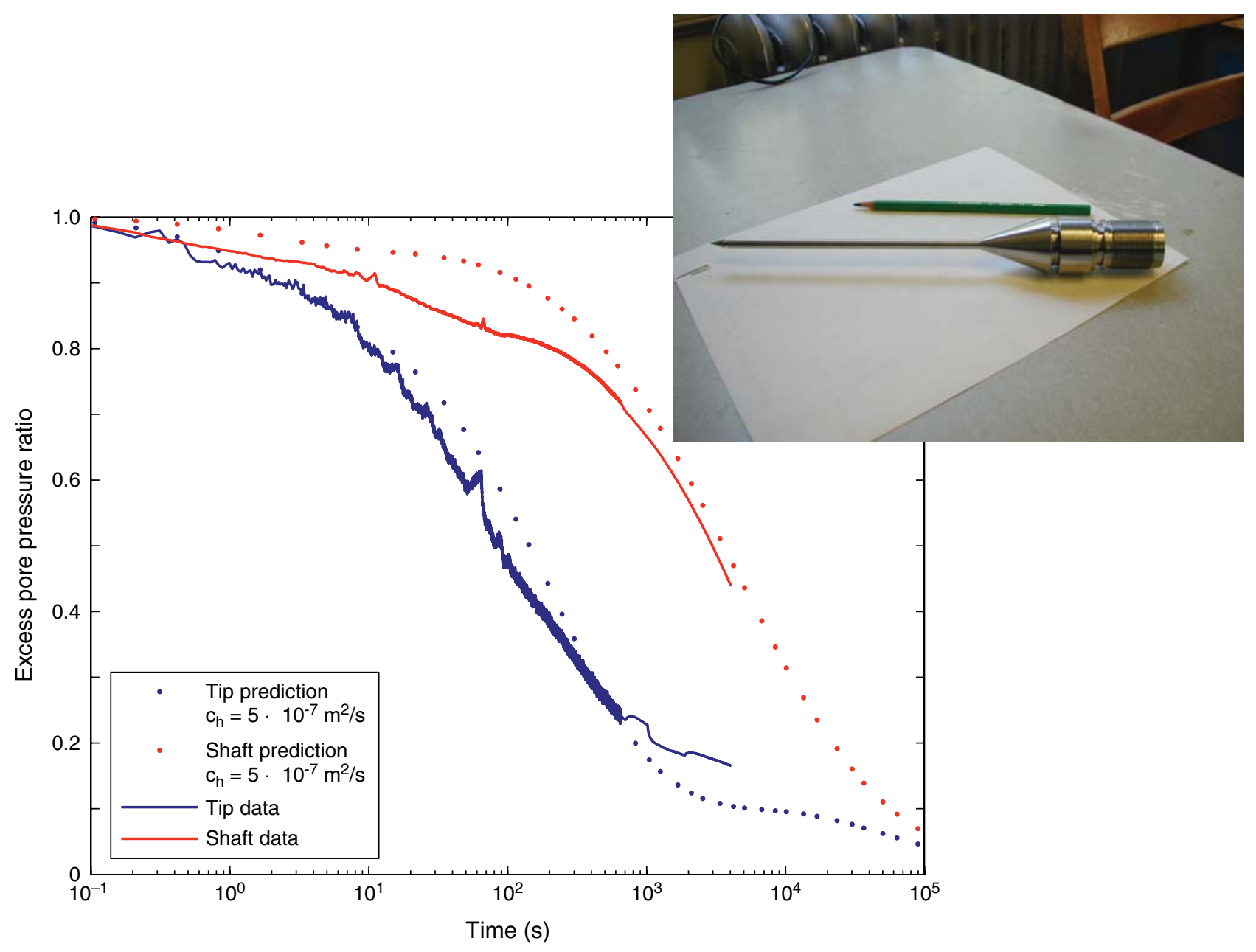


Figure F13. Combination diagram showing seismic strip chart, lithologic column with lithostratigraphic units from core description, downhole variations of gamma ray, resistivity, porosity, peak shear strength, and headspace methane contents at Site U1319. The time-depth correlation was achieved by converting wireline logs in time using the check shots obtained in Hole U1320A. SF = seafloor.

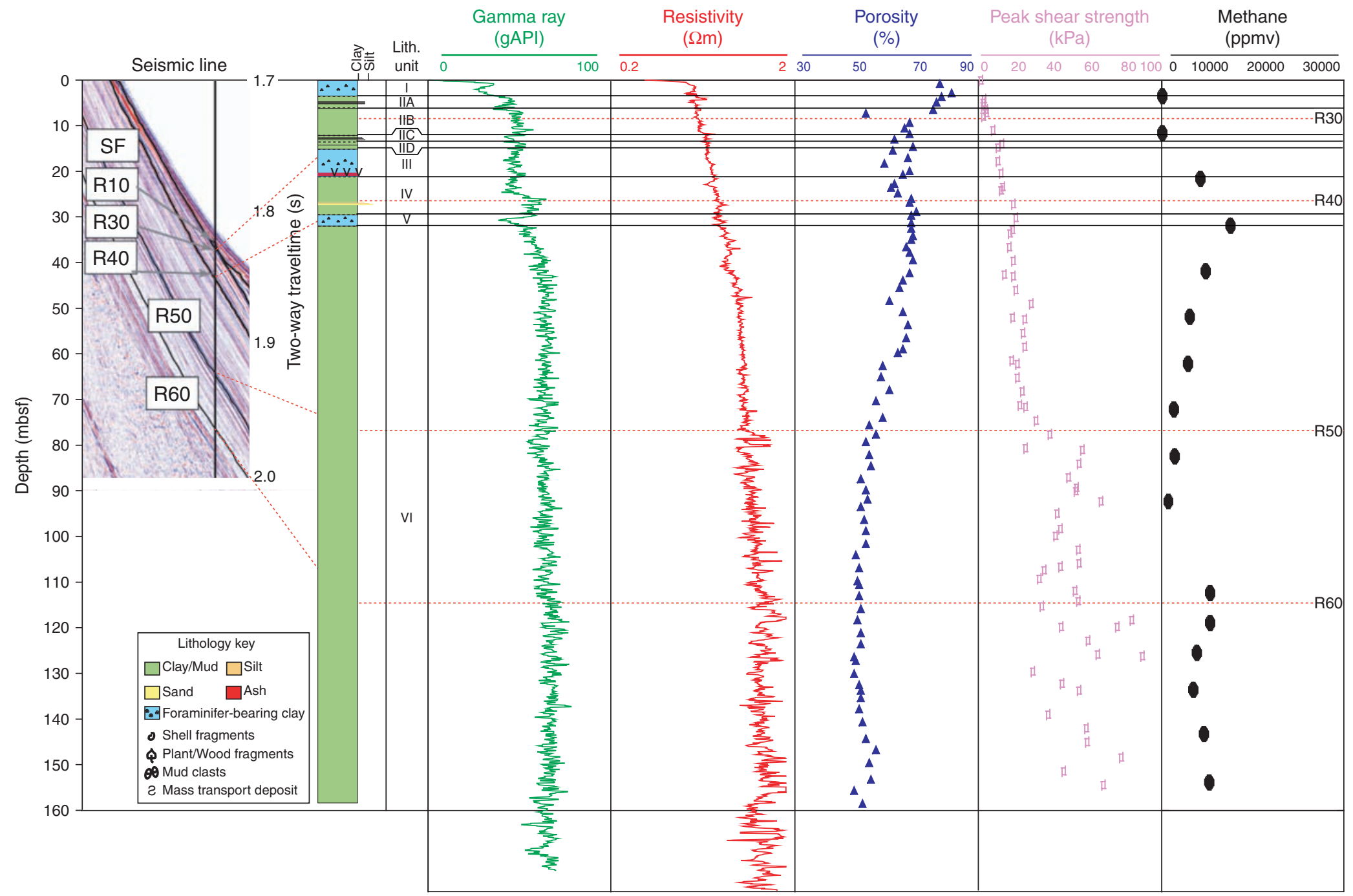


Figure F14. Combination diagram showing seismic strip chart, lithologic column with lithostratigraphic units from core description, downhole variations of gamma ray, resistivity, porosity, experimentally determined peak shear strength, and headspace methane contents at Site U1320. The time-depth correlation was achieved by converting wireline logs in time using the check shots obtained in Hole U1320A. SF = seafloor.

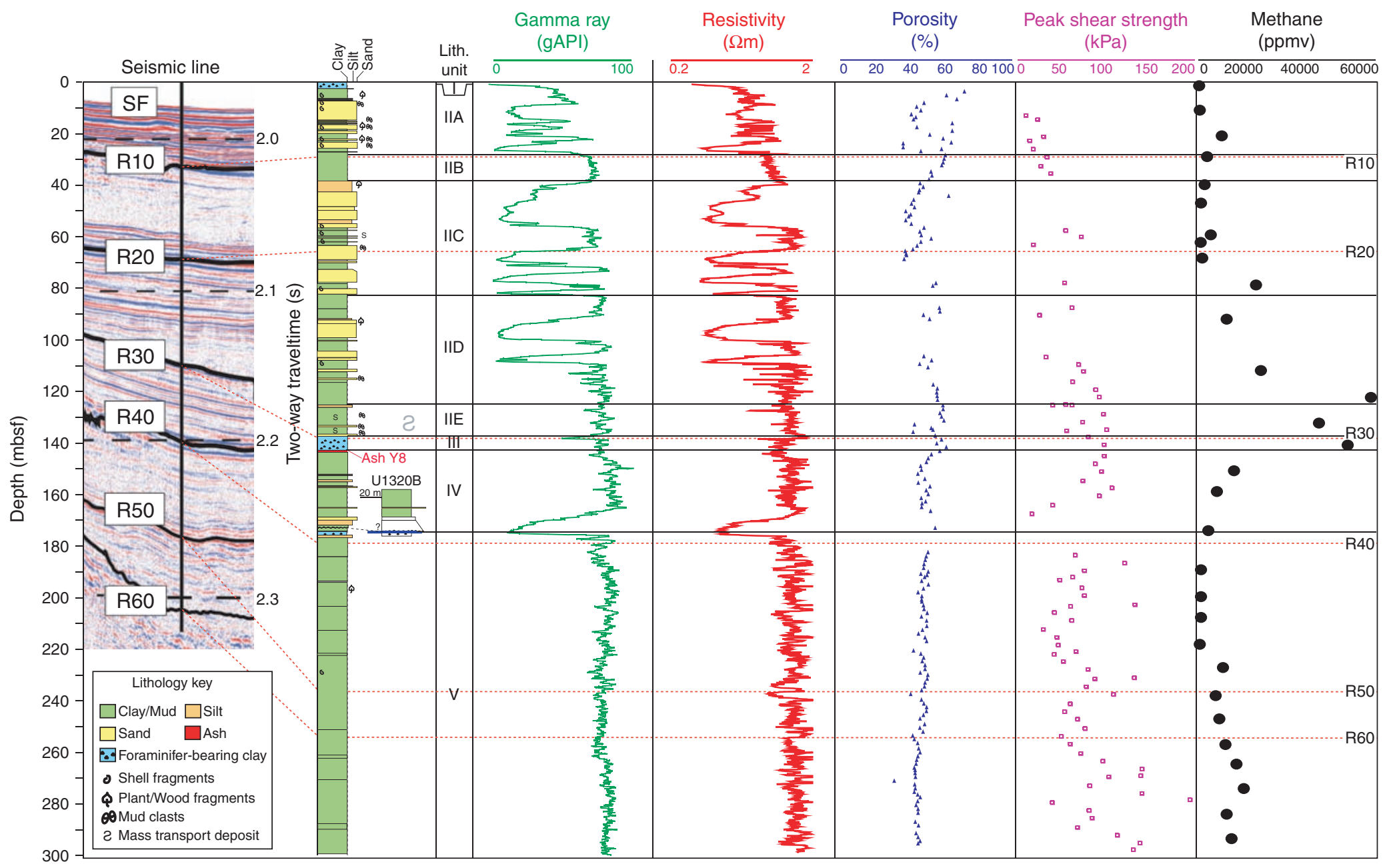


Figure F15. Combination diagram showing seismic strip chart, lithologic column interpreted from logging data, downhole variations of gamma ray intensity and resistivity, and log porosity at Site U1321. The timedepth correlation was achieved by converting wireline logs in time using the check shots obtained in Hole U1320A. SF = seafloor.

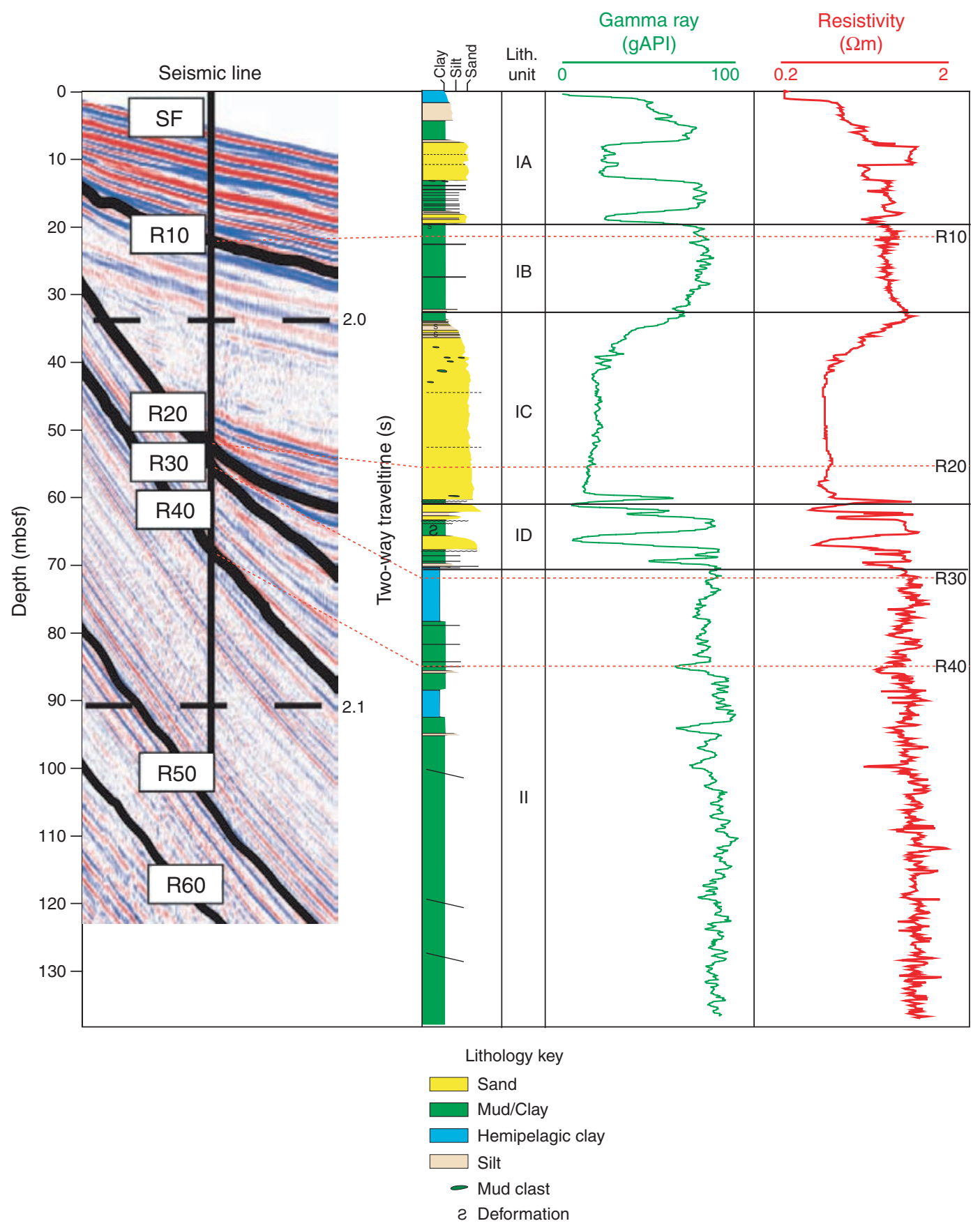


Figure F16. Combination diagram showing seismic strip chart, lithologic column with lithostratigraphic units from core description, downhole variations of gamma ray intensity and resistivity, porosity, experimentally determined peak shear strength, and headspace methane contents at Site U1322. SF = seafloor

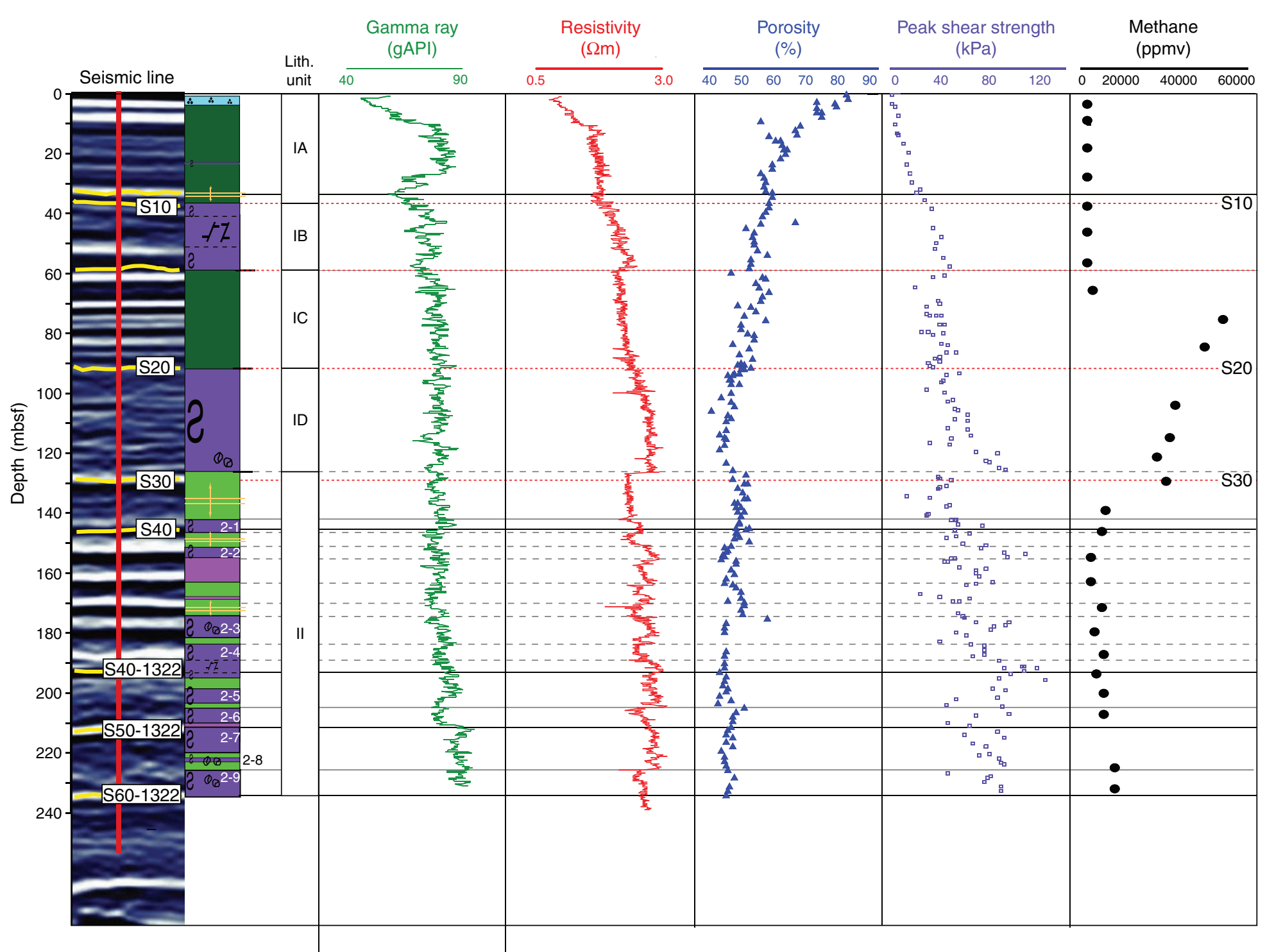


Figure F17. Combination diagram showing seismic strip chart, lithologic column interpreted from the logging data, downhole variations of gamma ray intensity and resistivity, and log porosity at Site U1323.

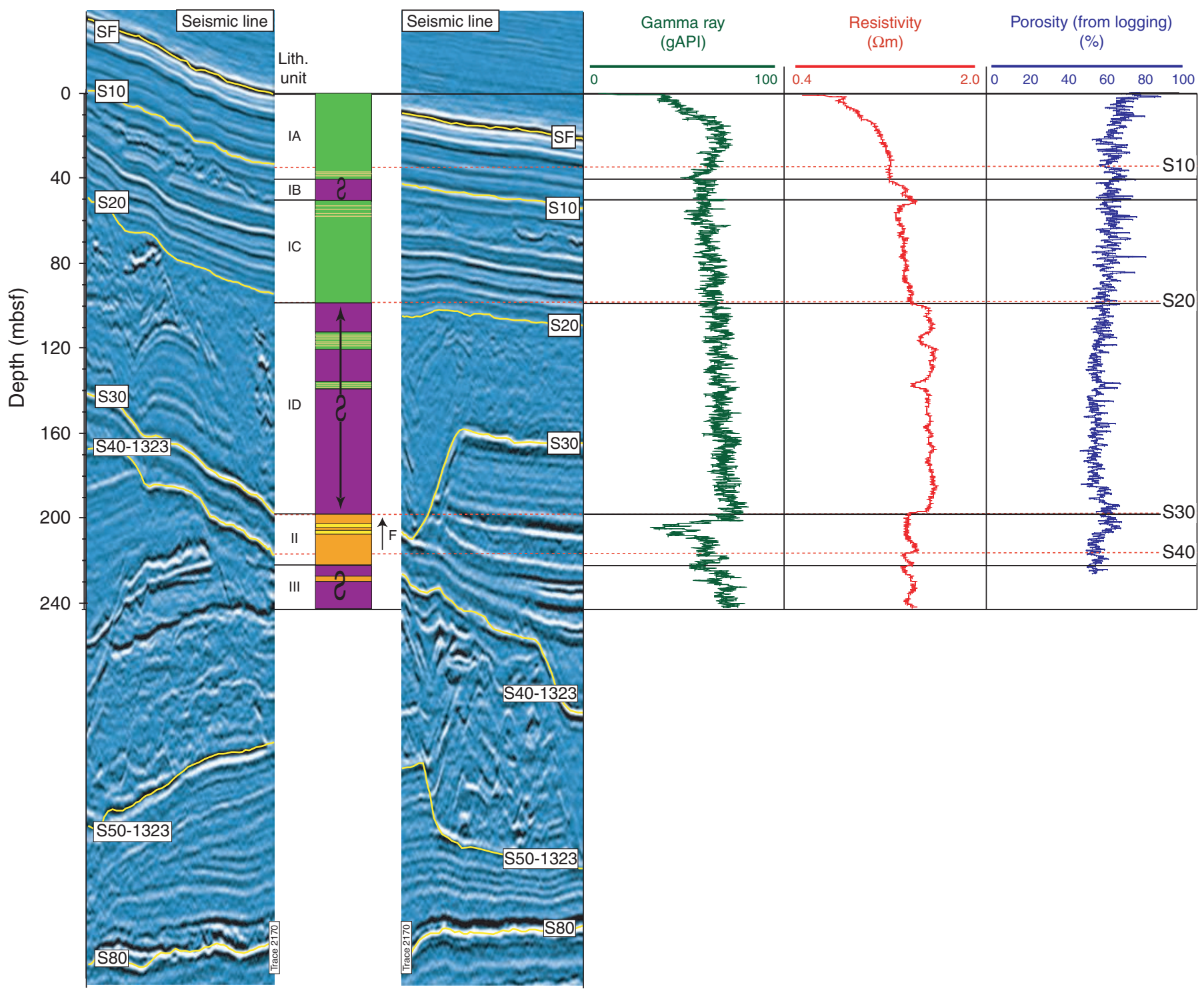


Figure F18. Combination diagram showing seismic strip chart, lithologic column with lithostratigraphic units from core description, downhole variations of gamma ray intensity and resistivity, porosity, experimentally determined peak shear strength, and headspace methane contents at Site U1324.

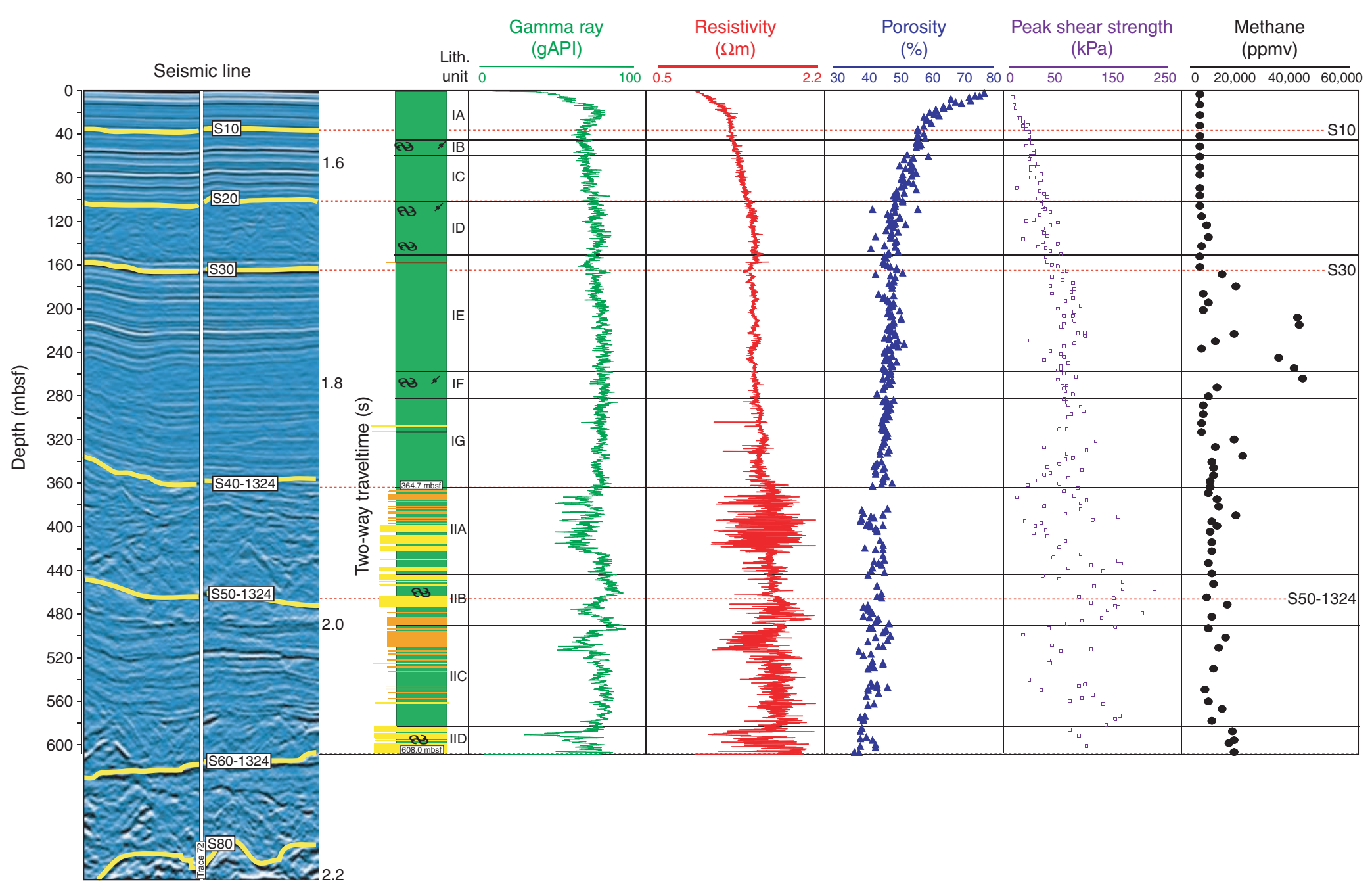


Figure F19. Mud trucks loading barite in Mobile, AL; 880 short tons (2000 lb/ton) of barite and 120 short tons of sepiolite were loaded on the JOIDES Resolution during port call. A total of $90 \%$ of these supplies were used during the expedition.

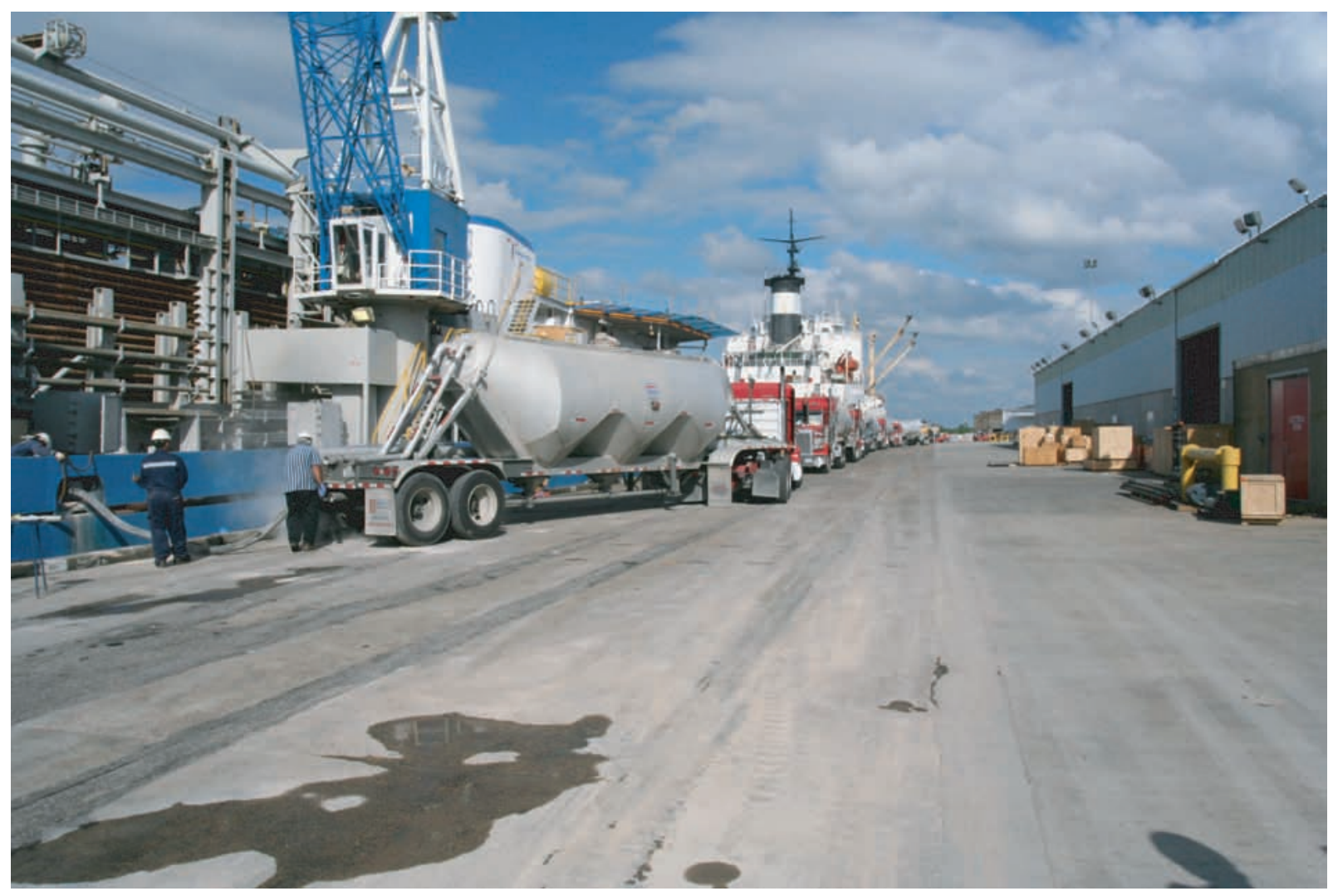


Figure F20. Pressure vs. depth plot illustrating the effect of drilling with weighted mud. Normally the JOIDES Resolution drills with seawater. Thus, borehole pressure follows hydrostatic pressure. If the formation is overpressured (the pore pressure is greater than the hydrostatic pressure at any depth), permeable, and unconsolidated, there is danger that there will be flow of water and sand into the borehole. To counter this effect, weighted mud was used during drilling. A $10.5 \mathrm{ppg}$ mud weight raised the formation pressure to approximately one-third of the way between hydrostatic and lithostatic, whereas a $12.5 \mathrm{ppg}$ mud would raise the borehole pressure to more than half of the distance from hydrostatic to lithostatic pressure.

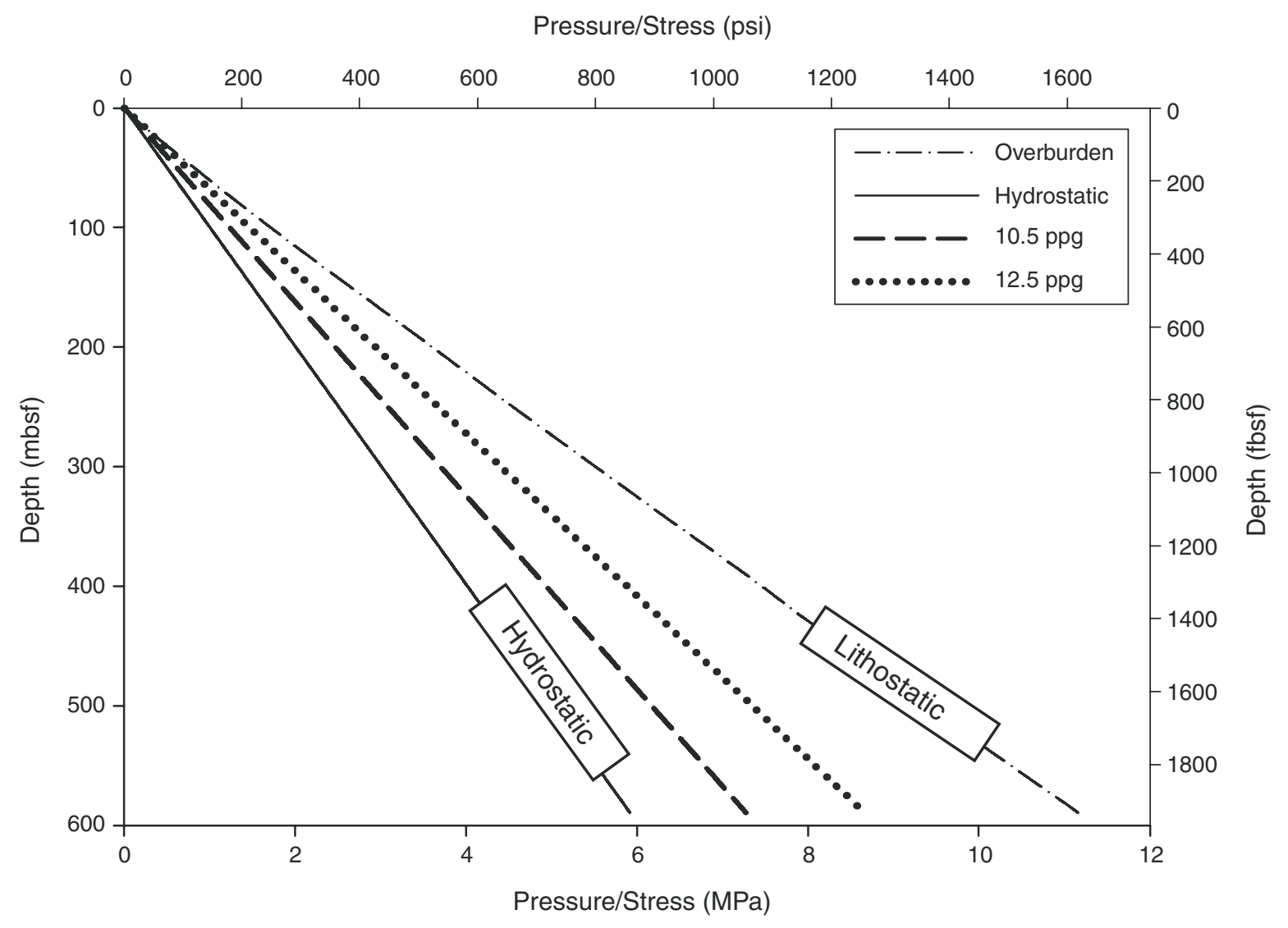


Figure F21. Measurement-while-drilling results at Site U1323. Annular pressure while drilling (APWD), annular pressure in excess of hydrostatic $\left(\mathrm{APWD}^{*}\right)$, and equivalent circulating density referenced to the seafloor $\left(\mathrm{ECD}_{\mathrm{rs}}\right)$ at Hole U1323A. The $\mathrm{ECD}_{\mathrm{rsf}}$ and $\mathrm{APWD}^{*}$ curves show characteristic decreasing and increasing trends, respectively, over the upper 150 mbsf. At 198 mbsf, a $3 \mathrm{~m}$ thick sand layer recorded an increase in APWD of $\sim 150$ psi over the background drilling pressure. This was interpreted to record flow of sand into the borehole. Mud weight was raised and the well was ultimately cemented and abandoned at 238 mbsf. TWT = two-way travel time, GR = gamma radiation. $\mathrm{SF}=$ seafloor.

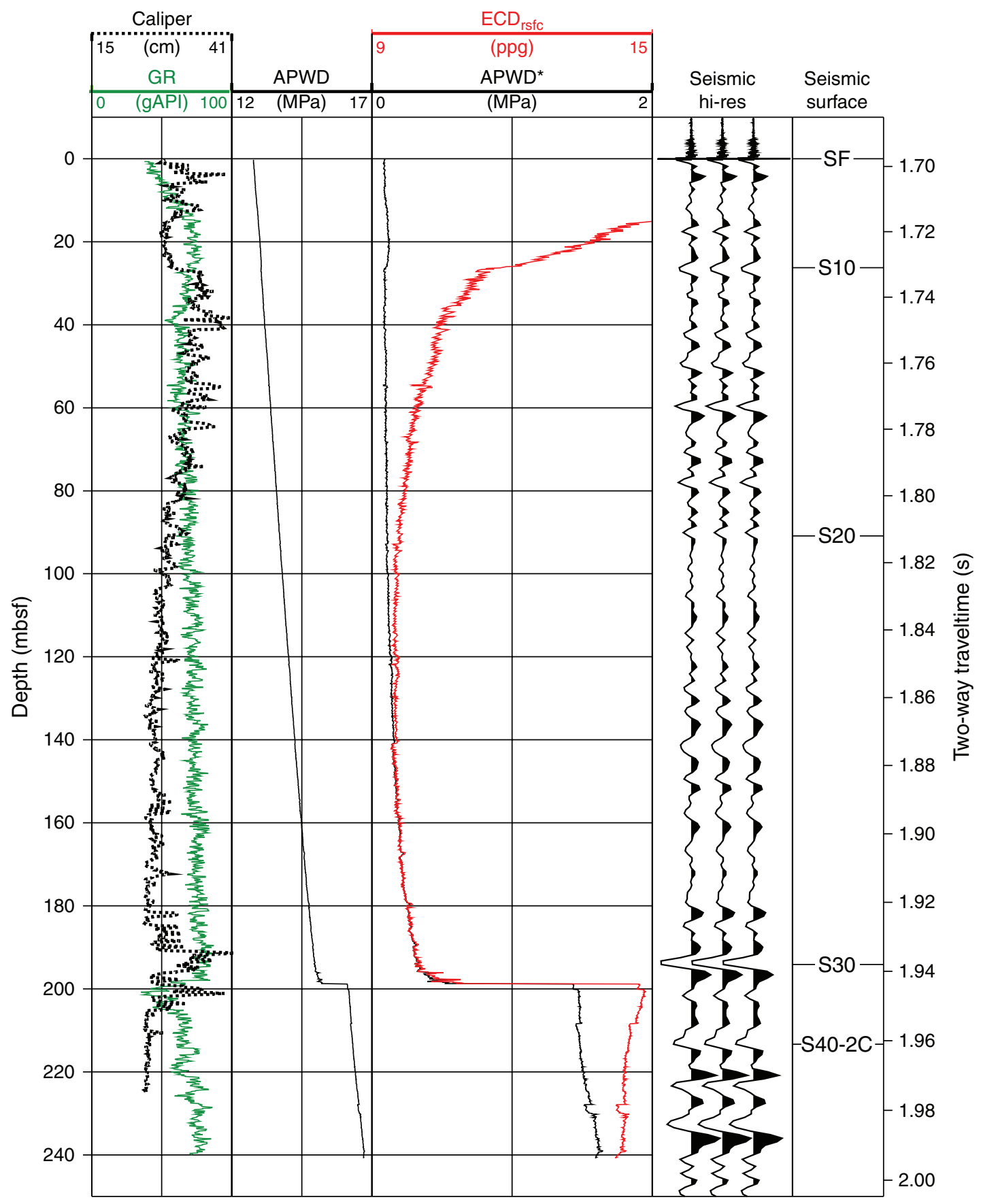


Figure F22. T2P (foreground) and DVTPP (background). Both tools measure formation pressure by being forced into the formation by the drill string. The T2P is significantly narrower both at the tip and along the shaft than the DVTPP.

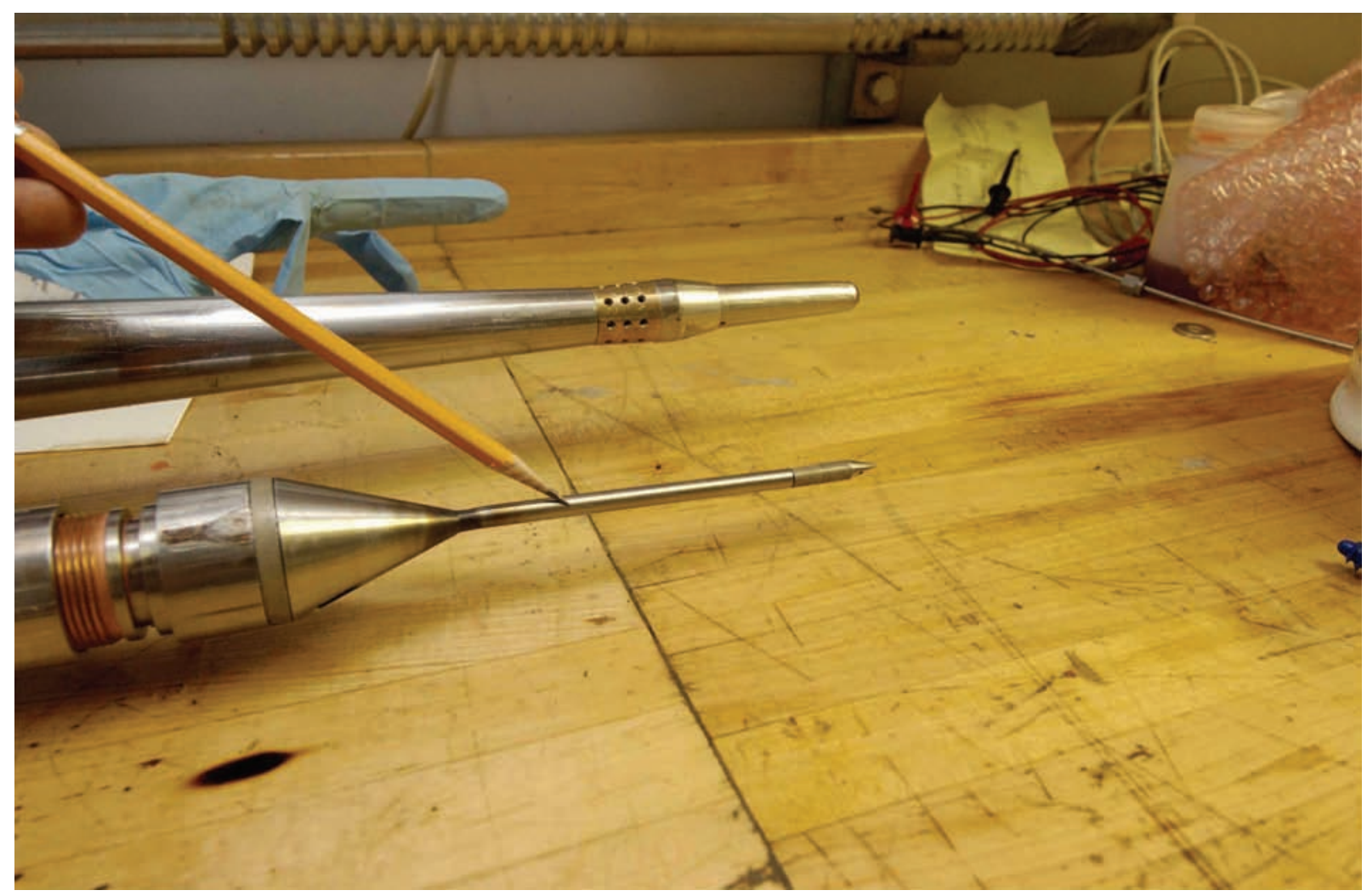


Figure F23. Characteristic deployments of the Davis-Villinger Temperature-Pressure Probe (DVTPP) and temperature/dual pressure (T2P) probe. A. Good deployments are characterized by an abrupt rise during penetration and a subsequent dissipation. B. Fair deployment. Many deployments recorded a subhydrostatic pressure when the drill string was raised in order to decouple the probe from the ship's motion. With time, the pressure equilibrated upward toward what is inferred to be the in situ pressure. C. "Leak" deployments had abrupt drops in pressure during the dissipation phase. This is interpreted to result from leakage within the tool into the air-filled chambers within the tools.

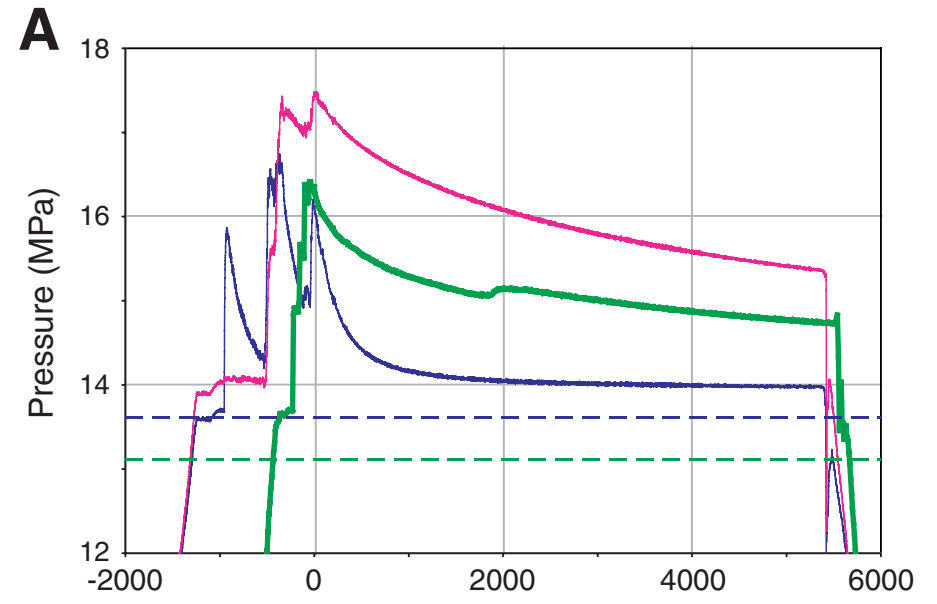

B

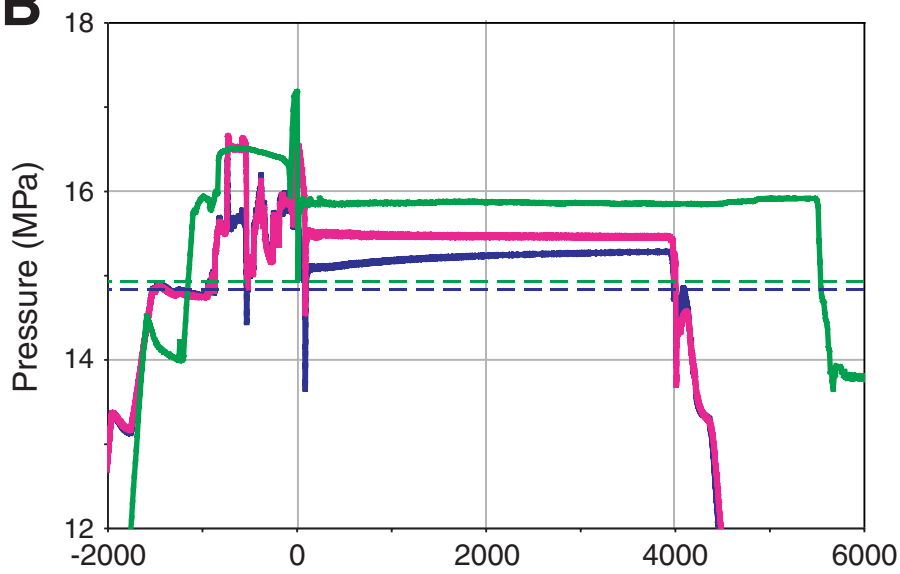

C

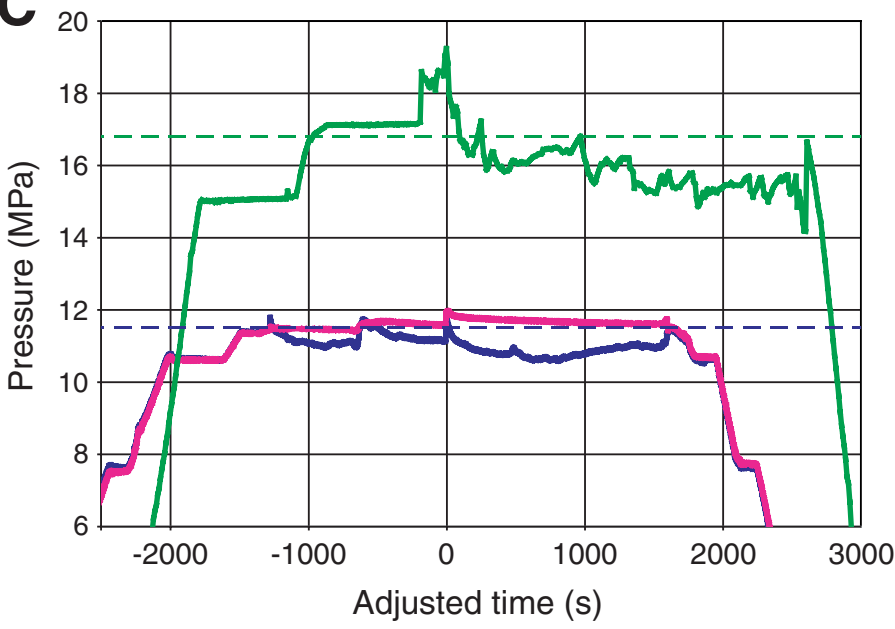

-T2P_16 tip

-T2P_16_shaft

- DVTPP_13

- - Hydrostatic at T2P_16

- - Hydrostatic at DVTPP_13
- T2P_20_tip
- T2P_20_shaft
- DVTPP_16
- - Hydrostatic at T2P_20
- - Hydrostatic at DVTPP_16

$$
\begin{aligned}
& \text { - T2P_6_tip } \\
& \text { - T2P_6_shaft } \\
& \text { - DVTPP_1 } \\
& \text { - - Hydrostatic at T2P_6 } \\
& \text { - - Hydrostatic at DVTPP_1 }
\end{aligned}
$$


Figure F24. There were 25 temperature/dual pressure (T2P probe deployments and 20 Davis-Villinger Temperature-Pressure Probe (DVTPP) deployments. Good deployments are illustrated in Figure F23A. Fair deployments contain some data that will give insight into in situ pressures (Fig. F23B). Poor deployments will most likely not yield information about in situ properties. During failed deployments, no meaningful data were retrieved.
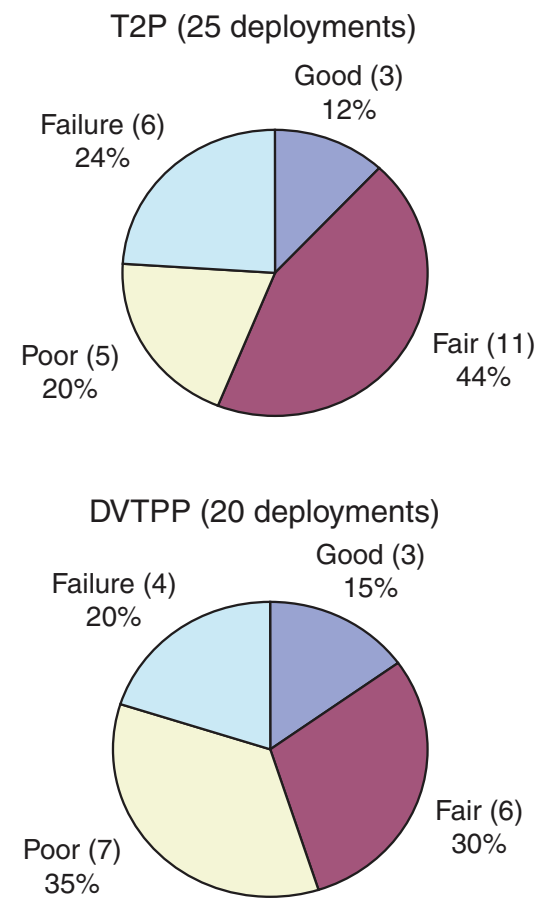
Figure F25. Illustration of the procedure for deployment of the penetration probes. A, B. The drill string pushes the probe into the formation. After penetration, the drill string is raised. C. The probe should stay in the ground and the bottom-hole assembly should slide upward as the drill string is raised a few meters. D. In many penetrometer deployments, when the drill string was raised it appears there was partial coupling between the drill string and tool. As a result, the tool was partially pulled out of its hole. E. During a successful penetration, there is an abrupt increase in pressure during penetration and then there is a slow dissipation of pressure after the tool is left in the ground. F. During unsuccessful deployments, the pore pressure record sharply drops during pullout. The result is a subhydrostatic pressure that gradually builds back to the formation pressure.
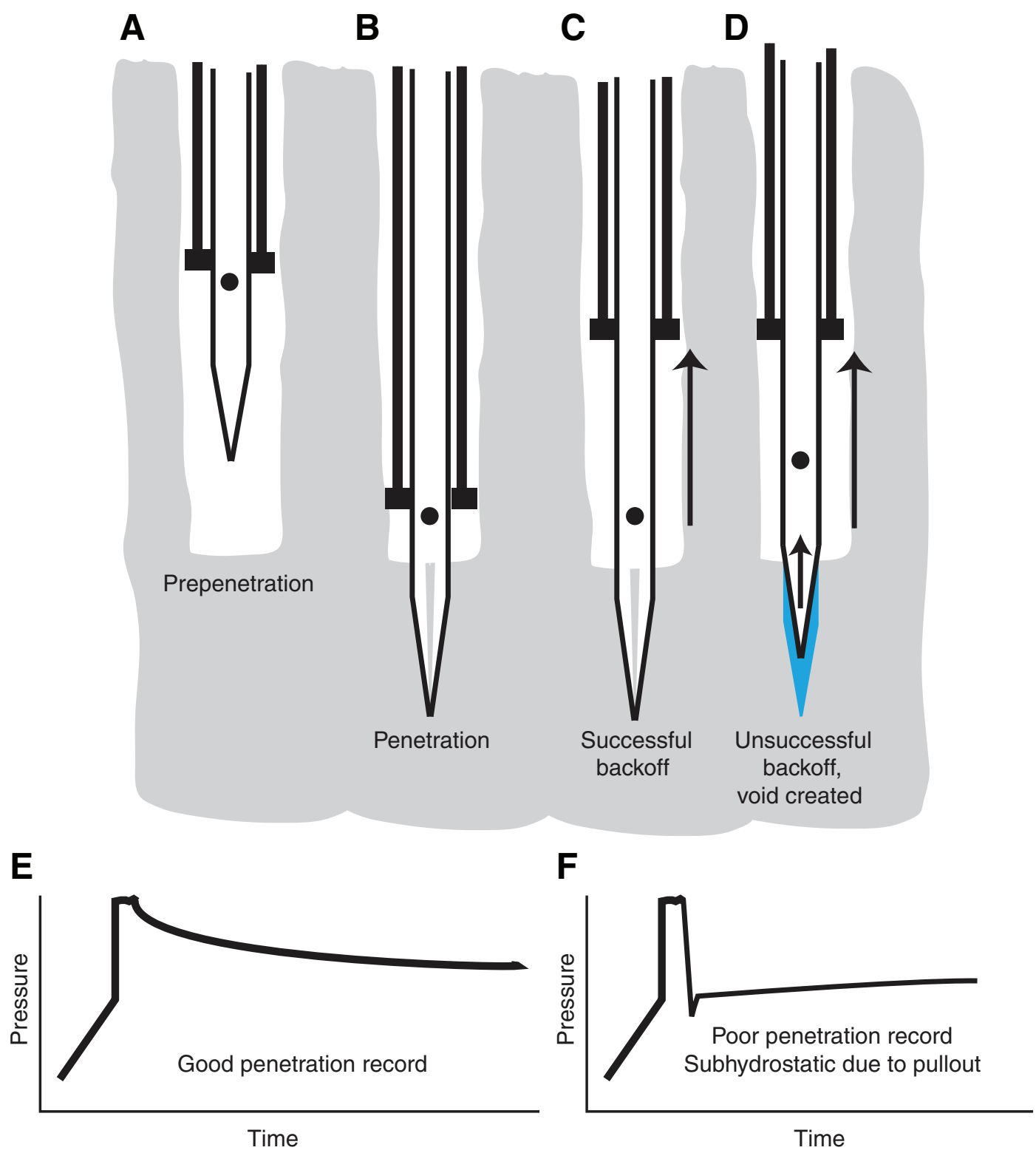
Figure F26. Dip-oriented seismic line across Brazos-Trinity Basin IV with LWD resistivity (RING) logs. Depth scale in the well logs were converted to time using the check shot survey in Hole U1320A. This time-depth curve was also used for Sites U1319 and U1321. SF = seafloor.

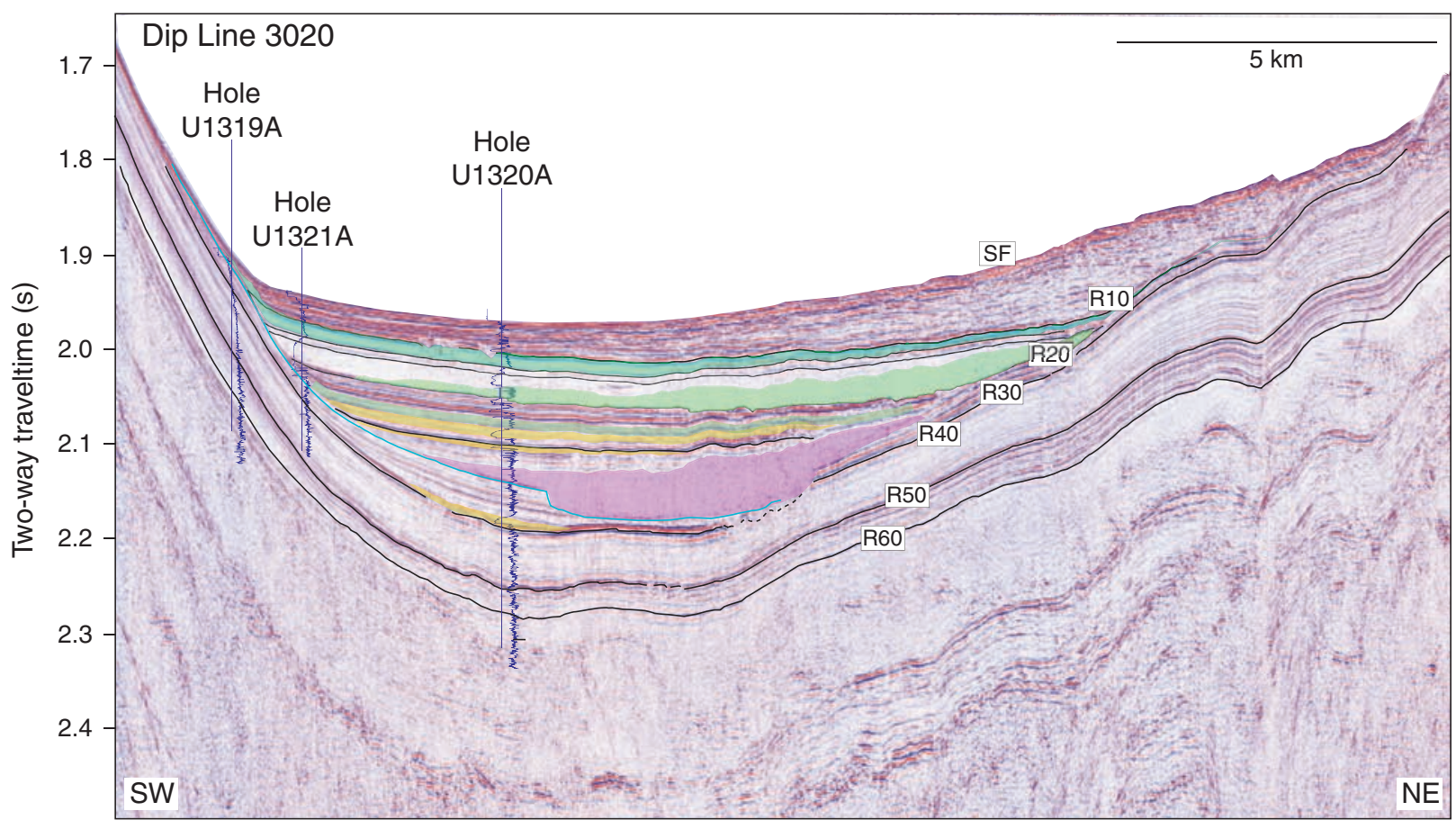


Figure F27. Strike-oriented seismic line across Site U1320 with LWD resistivity (RING) log. The logs were converted to depth using results from the check shot survey at this site. SF = seafloor.

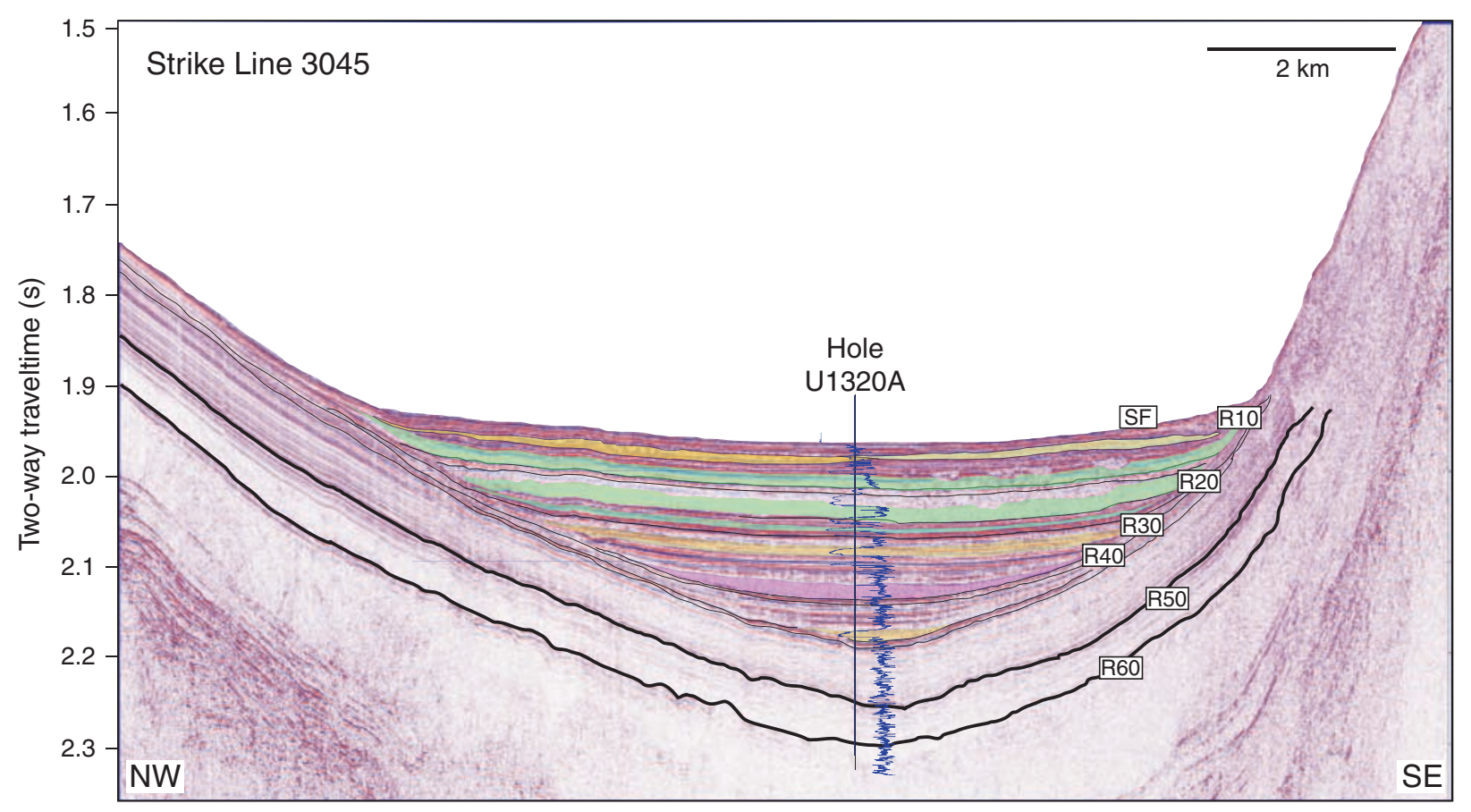


Figure F28. Preliminary age model of Brazos-Trinity Basin IV, integrating results from planktonic foraminifers, nannofossils, and magnetostratigraphy. Lower part of the diagram shows the sea level curve of Lambeck and Chappel (2001). MIS = marine isotope stage.

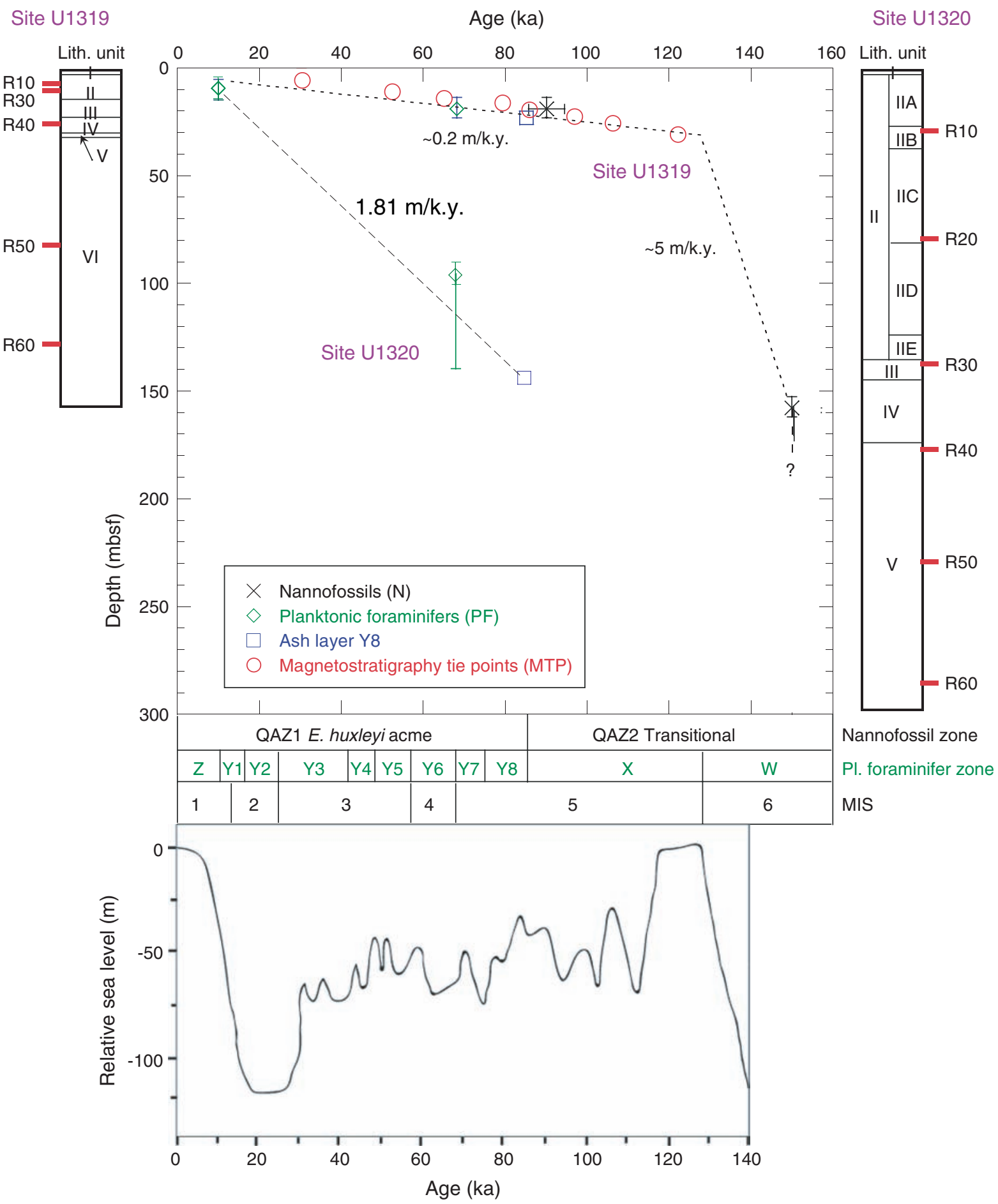


Figure F29. Stratigraphic cross-section of Brazos-Trinity Basin IV. The core and well logs are datumed at sea level. Stratigraphic ties between sites are based on seismic, lithology, log signature, and biostratigraphy. Each column contains a depth scale, a schematic lithology, gamma ray (GR) and resistivity logs (from LWD), and the depth of key seismic surfaces. In the core recovery diagram, black = cored, red $=$ overlap due to core expansion, and white $=$ no recovery.

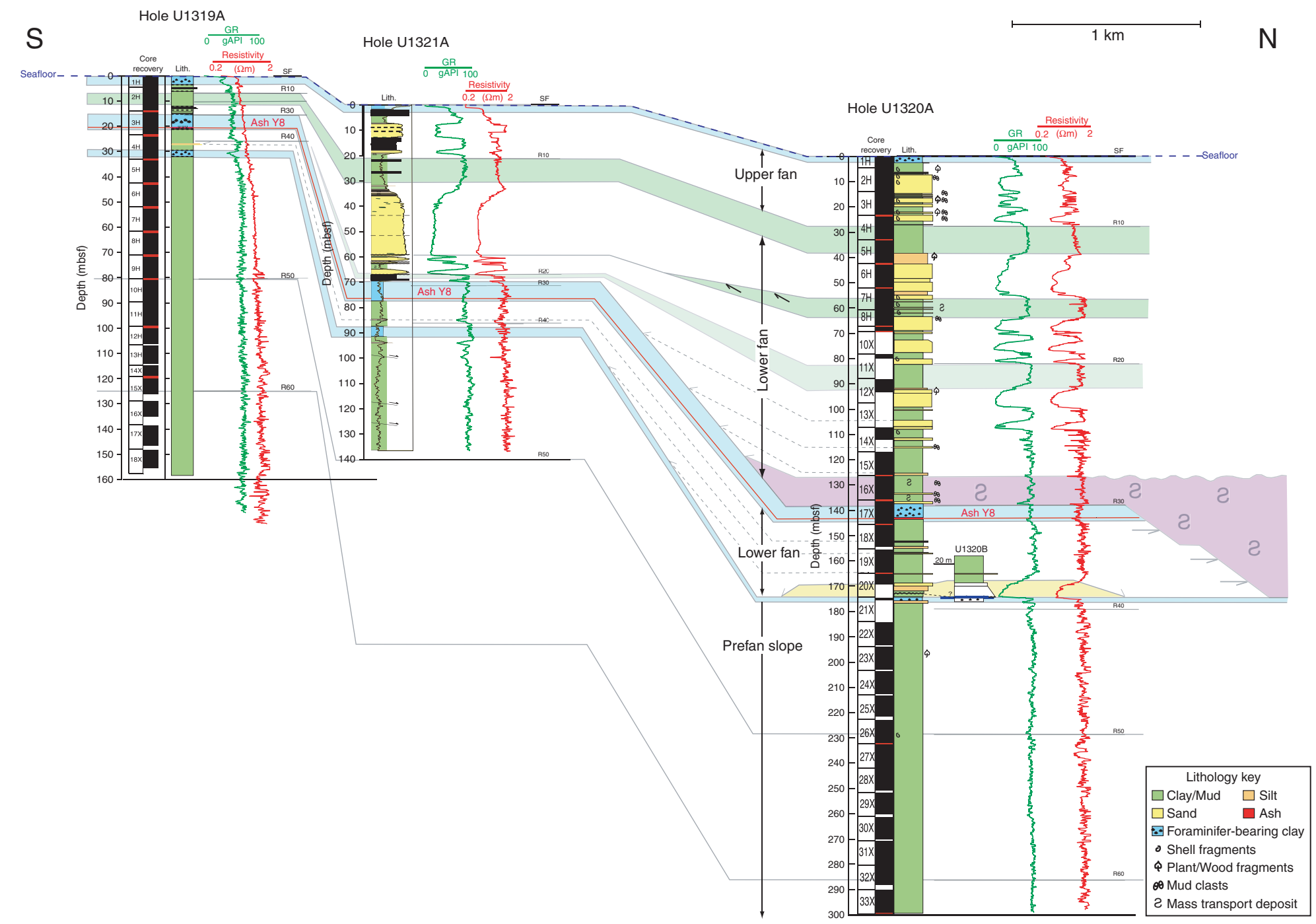


Figure F30. Selected core photographs illustrating facies encountered in each of the units. A. Turbidites in the upper fan sequence. B. Upper hemipelagic interval containing ash Layer Y8 (Drexler et al., 1980). Inset shows microphotographs of volcanic glass silt and sand. C. Thin-bedded turbidites in the lower fan sequence. D. Lower hemipelagic interval at the base of Brazos-Trinity Basin IV. E. Laminated and bioturbated mud in the prefan sequence.

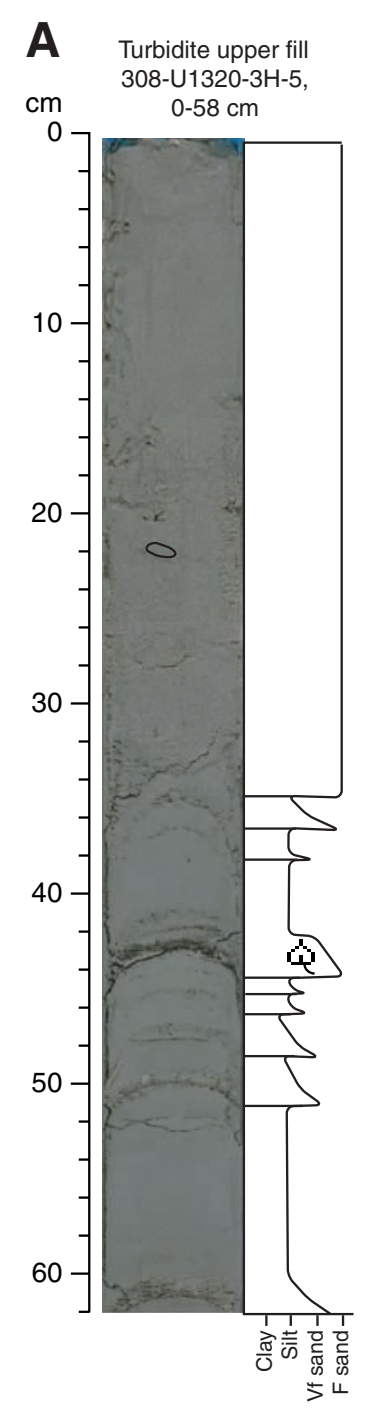

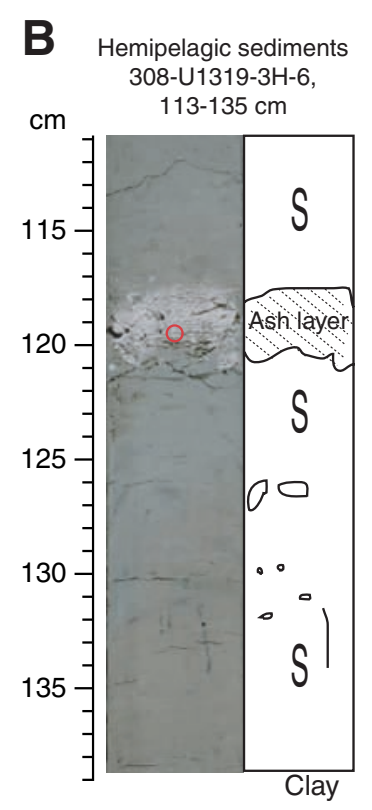

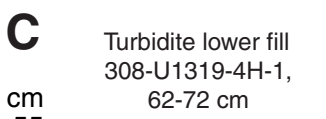
D Lower hemipelagic sediments
308-U1319-4H-5, $\mathrm{cm} \quad \begin{aligned} & 308-\mathrm{U} 1319-4 \mathrm{H} \\ & \mathrm{com}\end{aligned}$
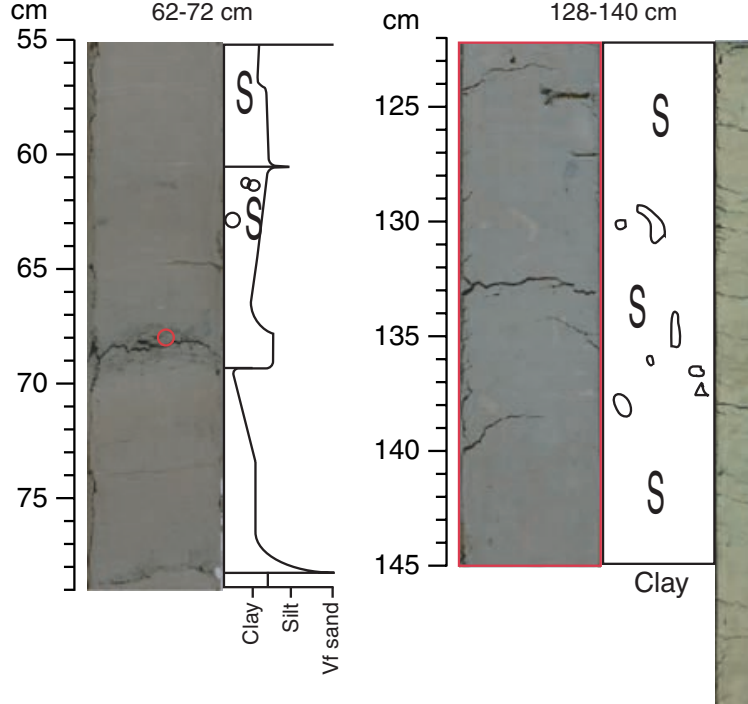

E

Underlying sediments $308-\mathrm{U} 1319-10 \mathrm{H}-4$,

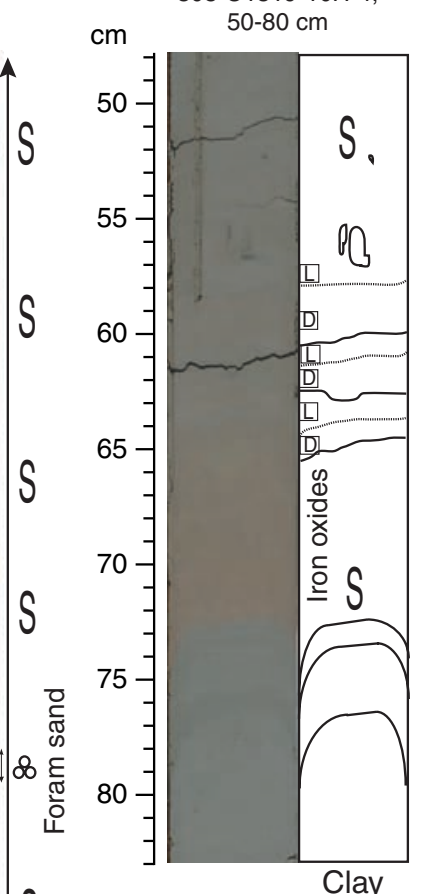

Micrographs of ash layer:
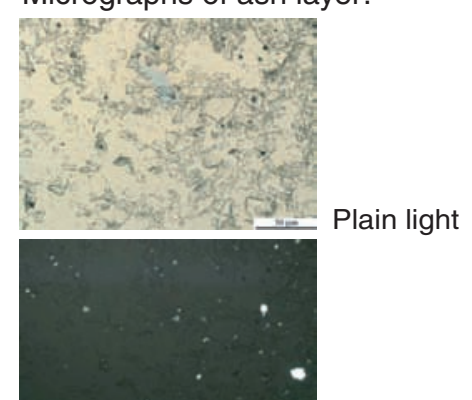

308-U1319-3H-6, $120 \mathrm{~cm}$
Key

\section{S Bioturbation}

$ऽ$ Burrows

\& Foraminifers

Q Plant fragment

(D) Dark color

$\square$ Light color 
Figure F31. Lithostratigraphic, LWD resistivity, and seismic reflector correlation between Sites U1322, U1323, and U1324. Seismic Reflectors S10-S30 can be traced through all sites and encompass a consistent sedimentary environment of mud and clay deposition interspersed with two mass transport events. Below S30, sediments at Site U1324 are characterized by the onset of conspicuous turbidite deposition in lithostratigraphic Unit II, whereas Site U1322 shows a concentration of mass transport deposits in lithostratigraphic Unit II. Because the bases of Sites U1322 and U1324 (see Fig. F32) are approximately the same age, the contrasting deposits represent approximate time-equivalent facies.

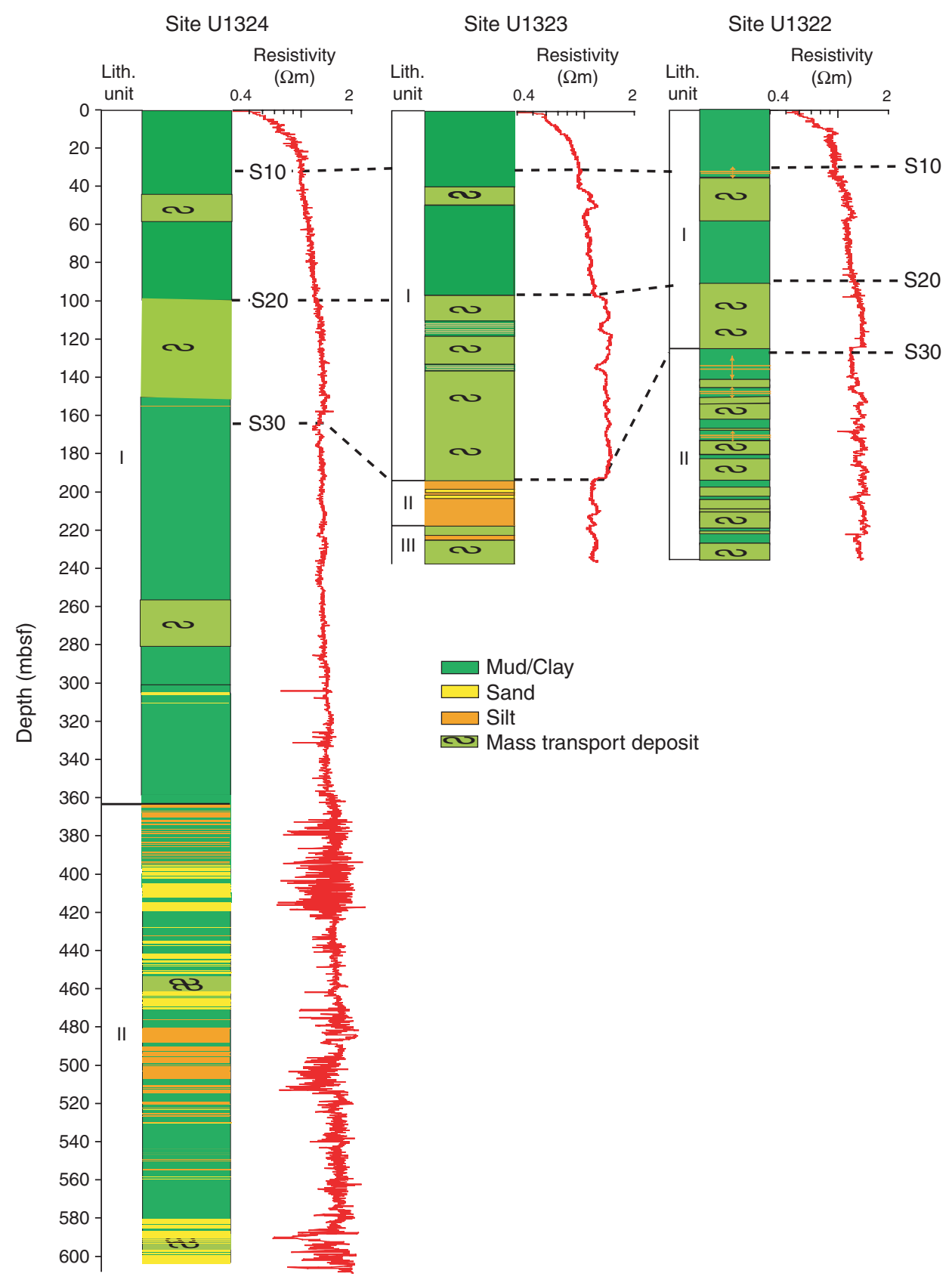


Figure F32. Summary of age constraints from microfossils and magnetostratigraphy from Sites U1322 and U1324. Black dashed line shows best-estimate age curve from cores that is additionally projected to the base of the Blue Unit. The Blue Unit was not penetrated during Expedition 308, but its age is estimated from industry penetration in the area (Winker and Booth, 2000). Sedimentation rates are similar at both sites from present to about $24 \mathrm{ka}$, then diverge below. The turbidite deposition at the base of Site U1324 accounts for a much higher rate of sedimentation than that observed over a similar time interval at Site U1322. MIS = marine isotope stage, LAD = last-appearance datum.

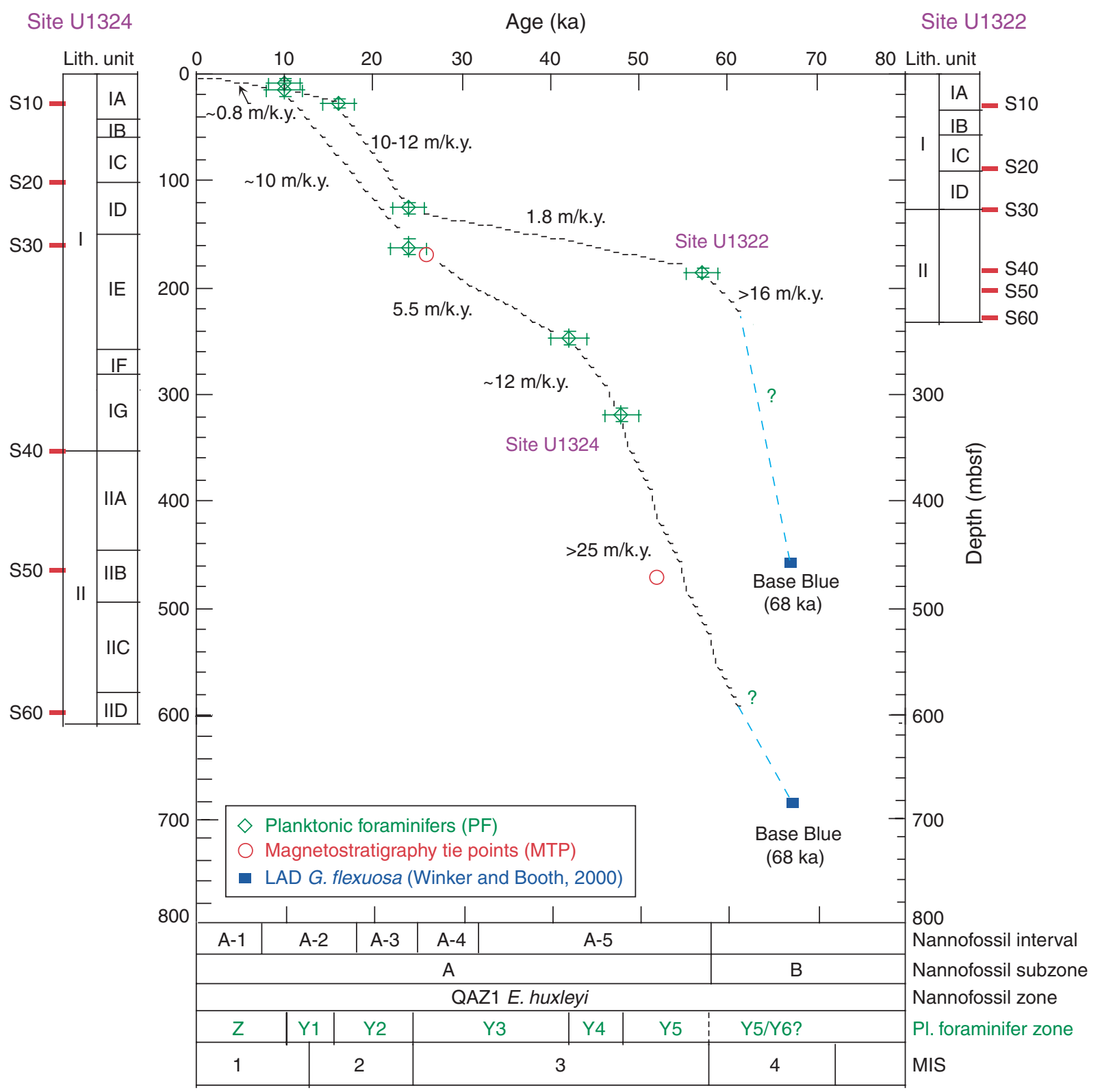


Figure F33. Seismic data and line-drawing interpretation of Sites U1322, U1323, and U1324. Ages in ka are estimated from biostratigraphy. Note the continuity of layers above seismic Reflector S30 and below S80. Between these reflectors, the depositional system shows contrasts across the Ursa Canyon east levee deposits. The latter may have formed a high that partitioned deposition. LAD = last-appearance datum.
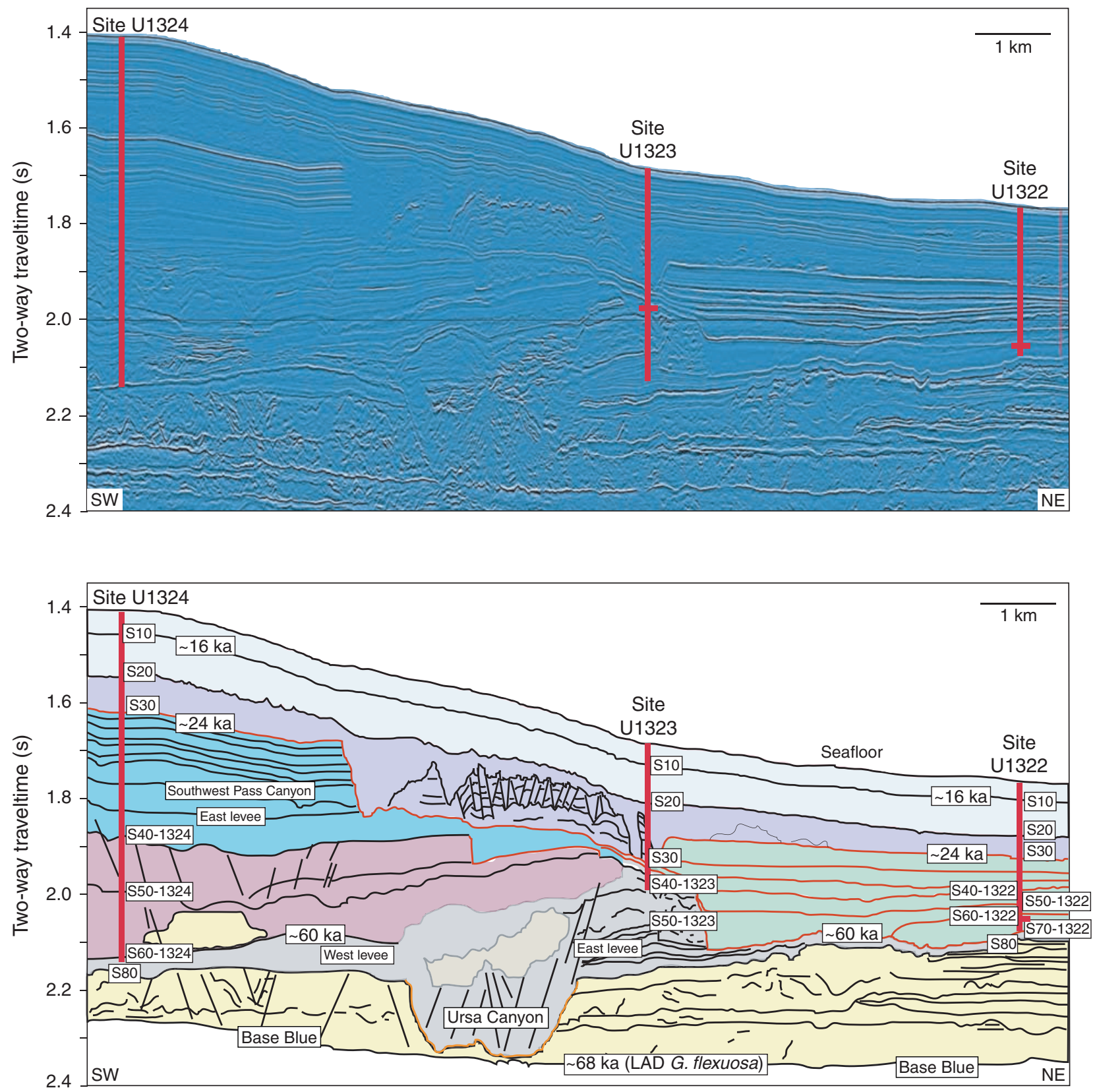
Figure F34. Summary of diagnostic features of mass transport deposits in the Ursa Basin. At seismic scale, mass transport deposits are characterized by discontinuous reflections and of transparent to low amplitude. At logging scale, mass transport deposits typically show increased resistivity and increased density, presumably due to transport-induced compaction. In resistivity-at-bit imaging, folds are apparent. Finally, at core scale, folding is common in mass transport deposits, some with half-wavelengths of a meter or more.

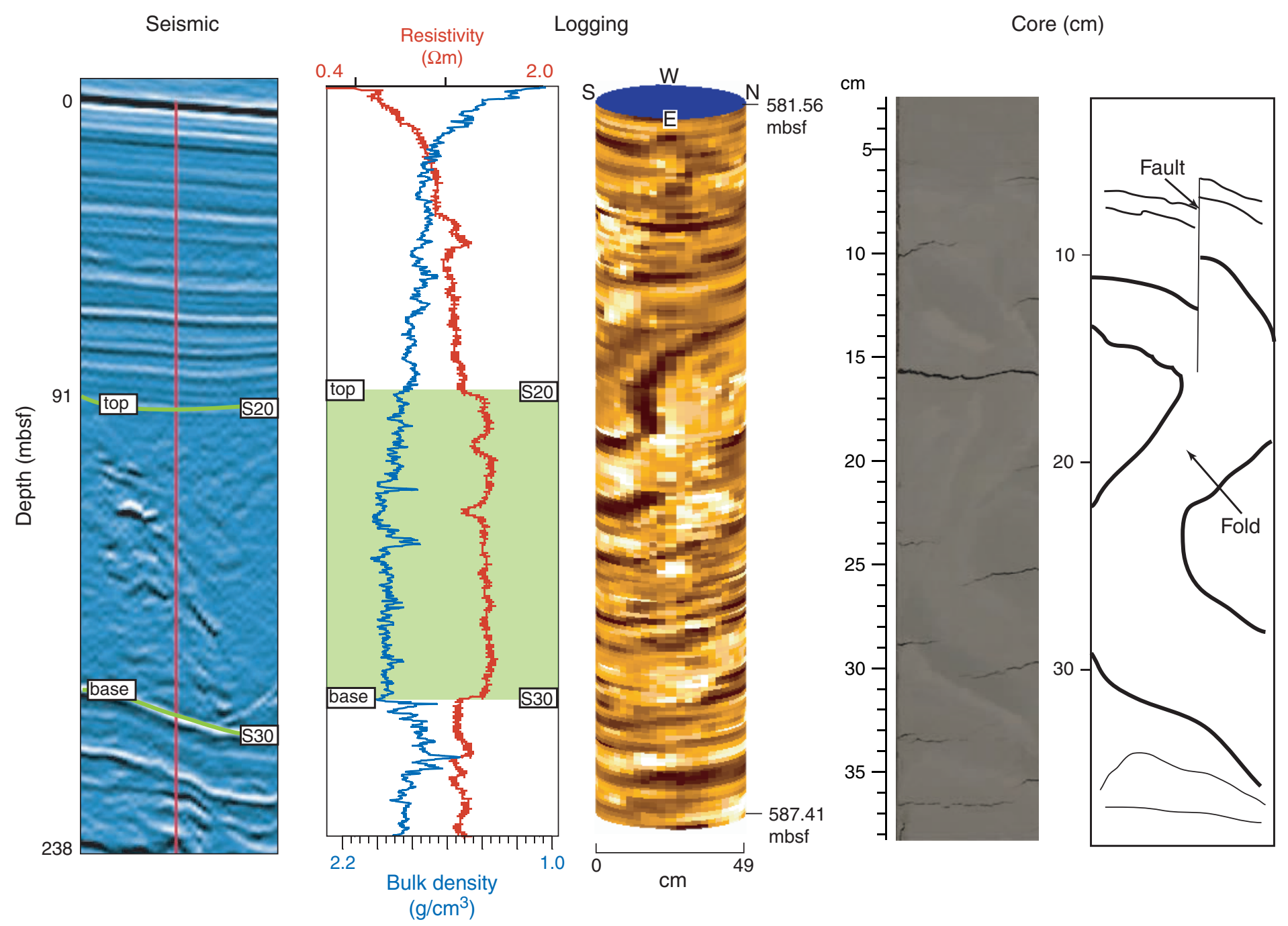


Figure F35. Porosity vs. depth below seismic Reflector R40 at Sites U1319, U1320, and U1321 from moisture and density (MAD) and loggingwhile-drilling (LWD) measurements. Main seismic reflectors are shown on the right.

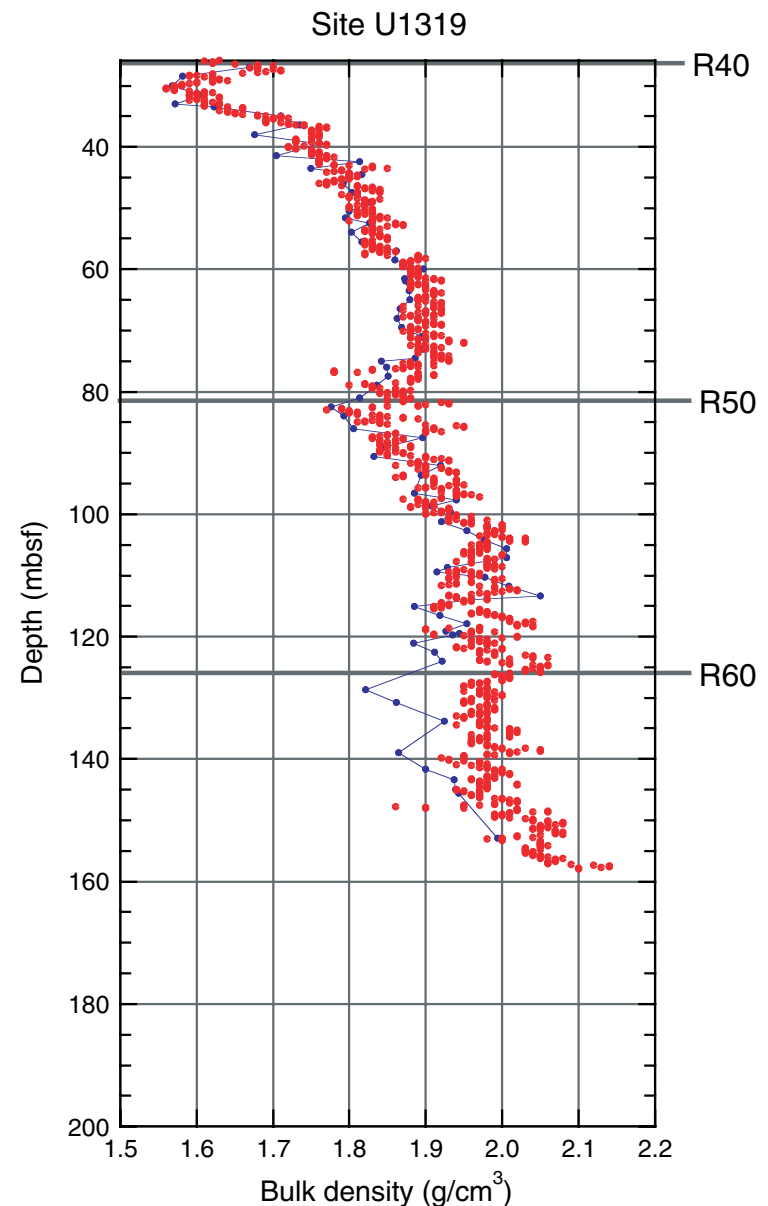

$\longrightarrow$ MAD

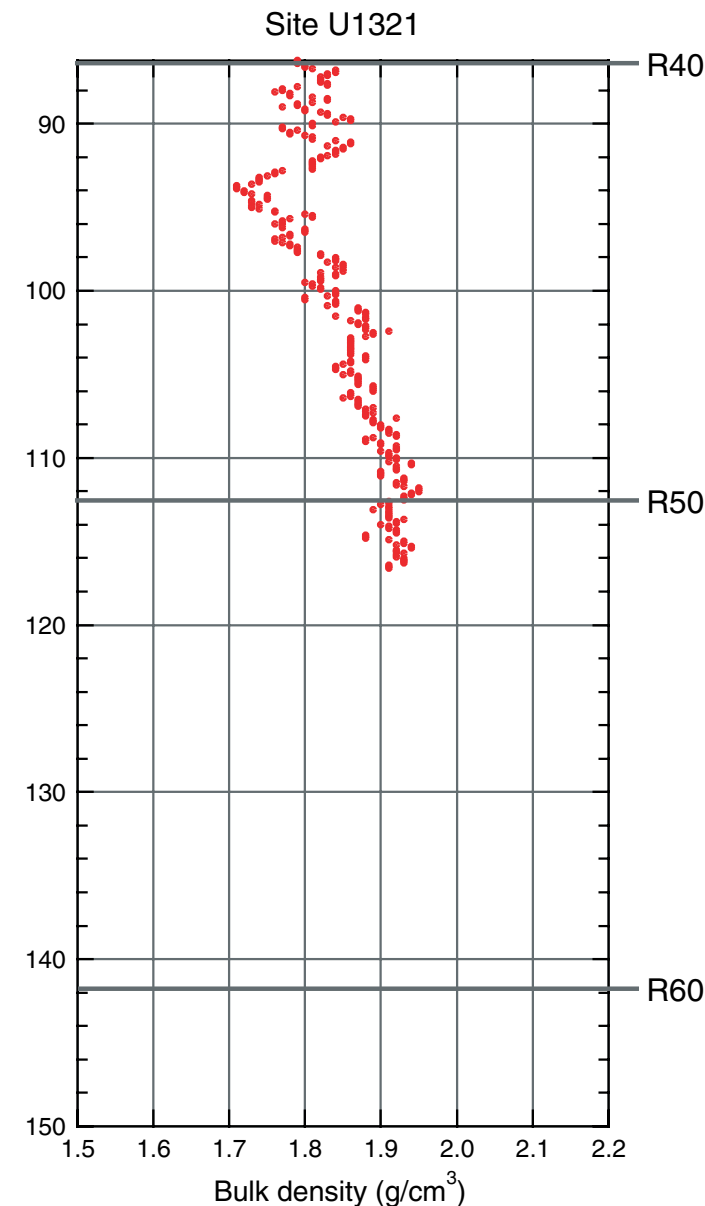

- LWD

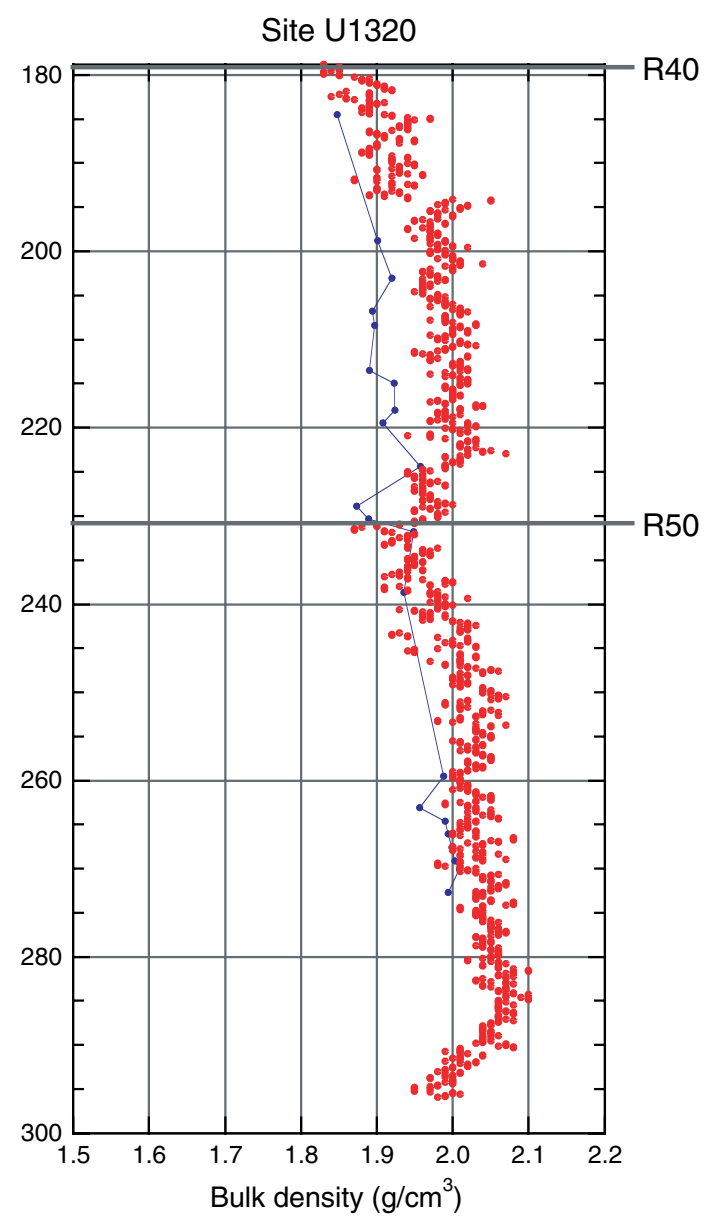

- MAD 
Figure F36. A. Void ratio $(e)$ vs. vertical hydrostatic effective stress $\left(\sigma_{\mathrm{vh}}{ }^{\prime}\right)$ for all sediments below seismic Reflector R40 at Sites U1319 and U1320. The reference void ratio $\left(e_{0}\right)$ and compression index $\left(C_{\mathrm{c}}\right)$ are derived from a fit of the type $e=e_{0}-C_{\mathrm{c}} \ln \left(\sigma_{\mathrm{vh}}{ }^{\prime}\right)$. B. Pore pressures for Site U1322 and U1324 are derived from parameters derived in A. assuming that trend at Site U1319 is hydrostatically pressured. Pore pressures recorded at the end of temperature/dual pressure (T2P) probe deployment are also shown. BSF = below seafloor.

A

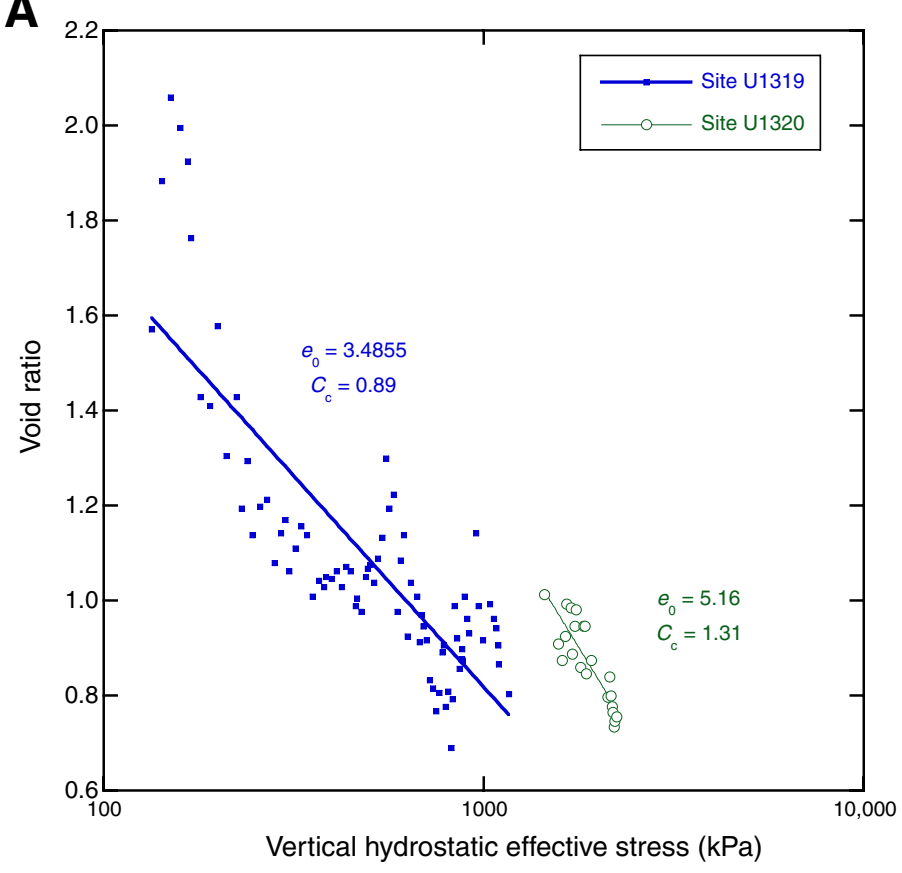

B

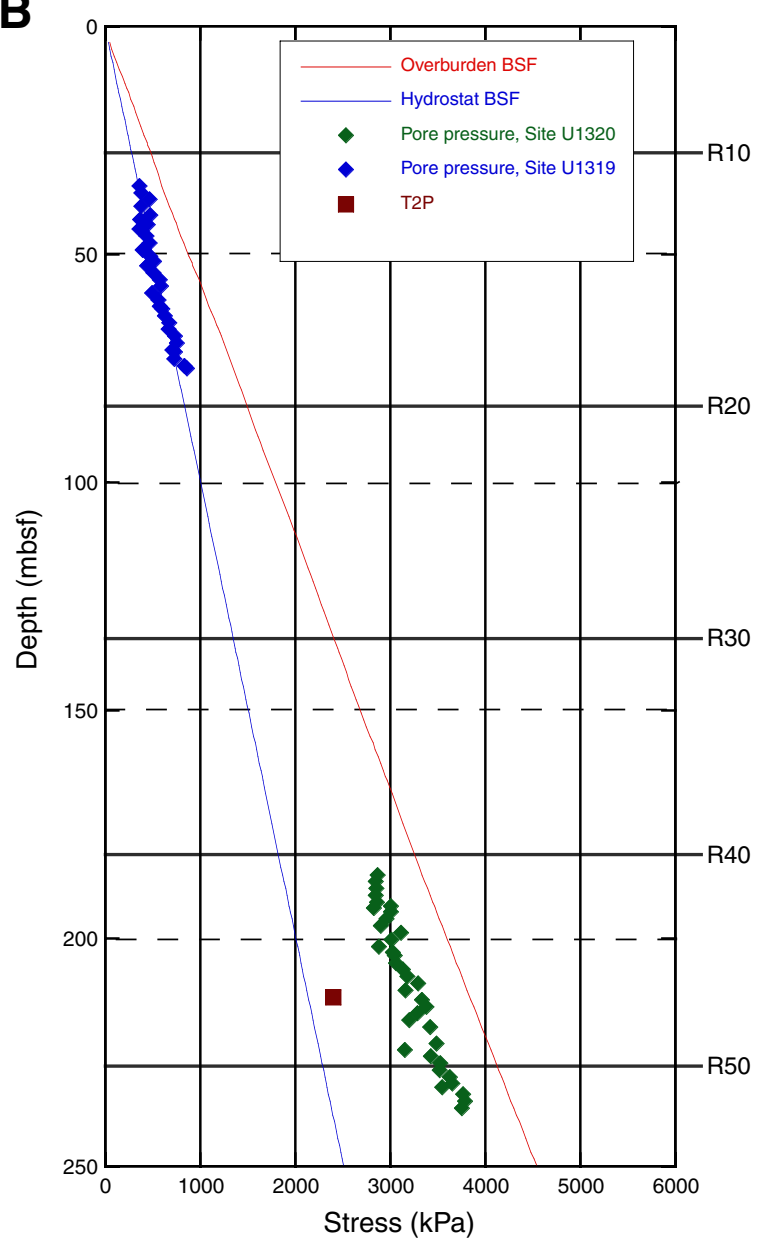


Figure F37. Porosity vs. depth at Sites U1322, U1323, and U1324 from moisture and density (MAD) and logging-while-drilling (LWD) measurements. The boxes on the left are the lithostratigraphic units; seismic reflectors are plotted on the right. Slump intervals are shaded.
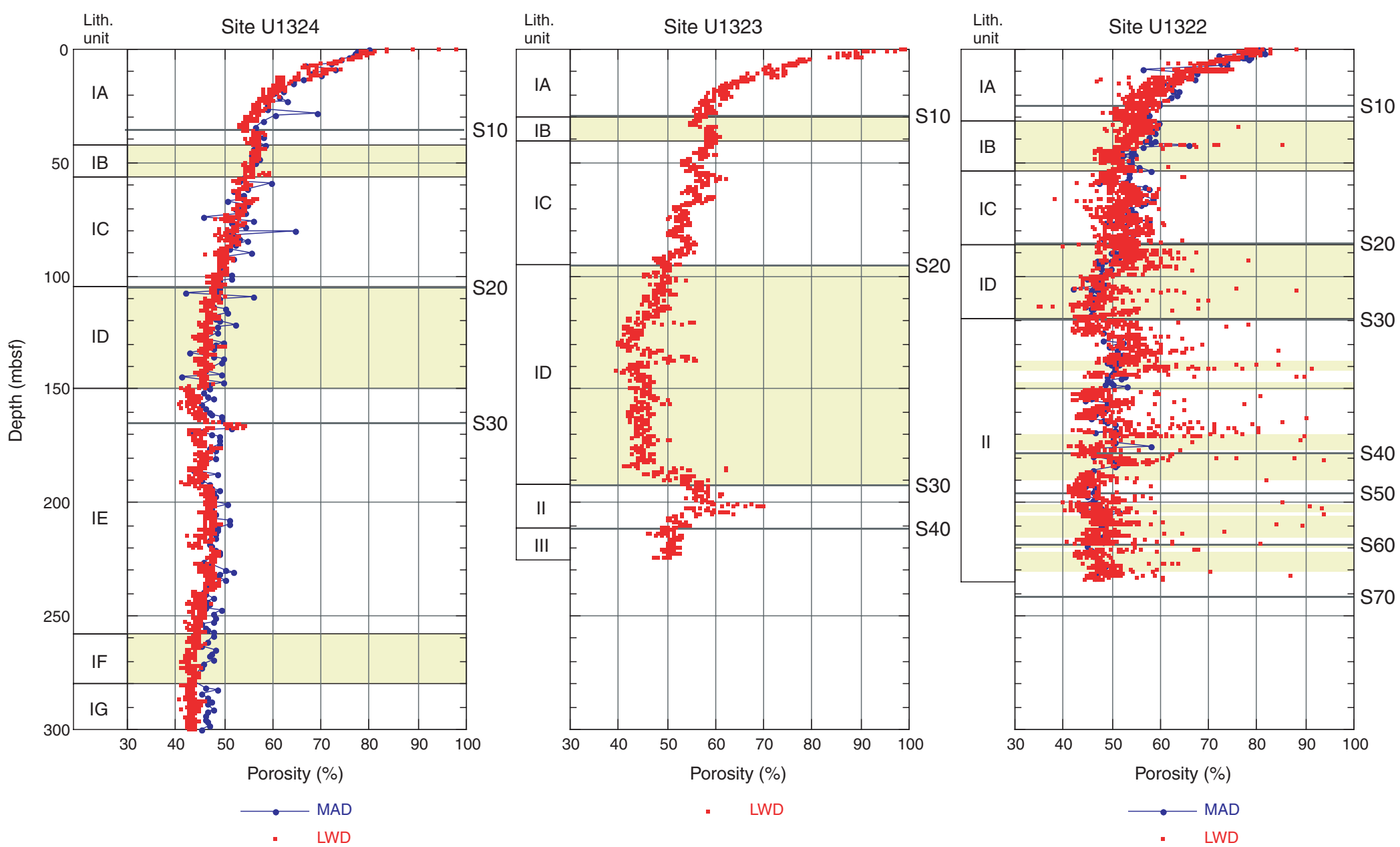
Figure F38. A. Void ratio (e) vs. vertical hydrostatic effective stress $\left(\sigma_{\mathrm{vh}}{ }^{\prime}\right)$ for lithostratigraphic Subunit IC at Site U1324. The reference void ratio $\left(e_{0}\right)$ and compression index $\left(C_{\mathrm{c}}\right)$ are derived from a fit of the type $e=e_{0}-C_{\mathrm{c}}$ $\ln \left(\sigma_{\mathrm{vh}}{ }^{\prime}\right)$. B. Pore pressures for Site U1322 and U1324 are derived from parameters derived in A. assuming that lithostratigraphic Subunit IC (blue dots) at Site U1324 is hydrostatically pressured. Pore pressures recorded at the end of temperature/dual pressure (T2P) probe (red triangles) and Davis-Villinger Temperature-Pressure Probe (DVTPP) (red squares) deployments are also shown. BSF = below seafloor, RM = running mean, PP = pore pressure.

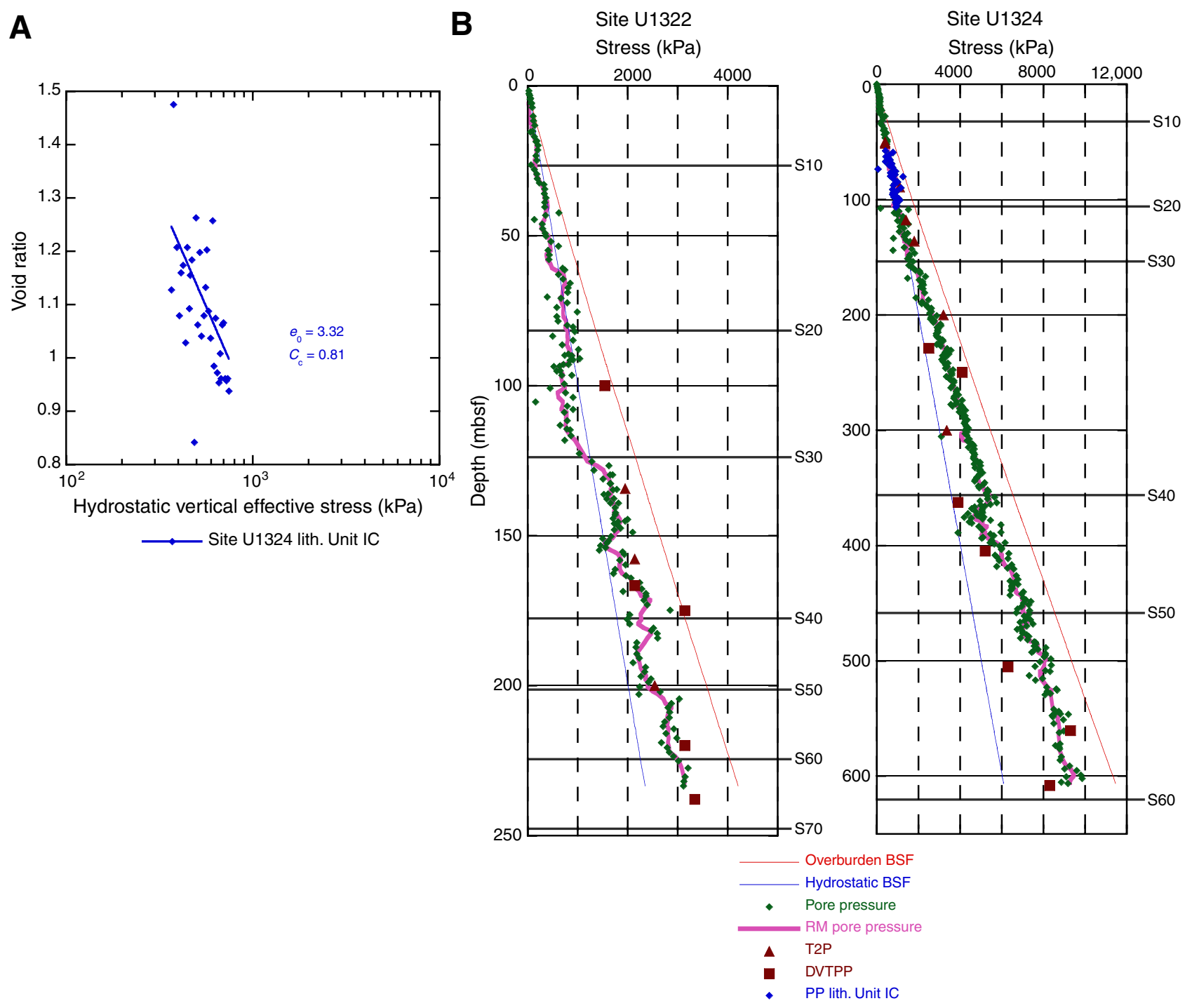


Figure F39. Porosity vs. depth at all Ursa Basin and Brazos-Trinity Basin IV sites from LWD data. The values associated with washout zones as indicated from the caliper log are not shown. Sites U1319 and U1320 are located in Brazos-Trinity Basin IV and the sites in the Ursa Basin are represented by the data from Site U1324.

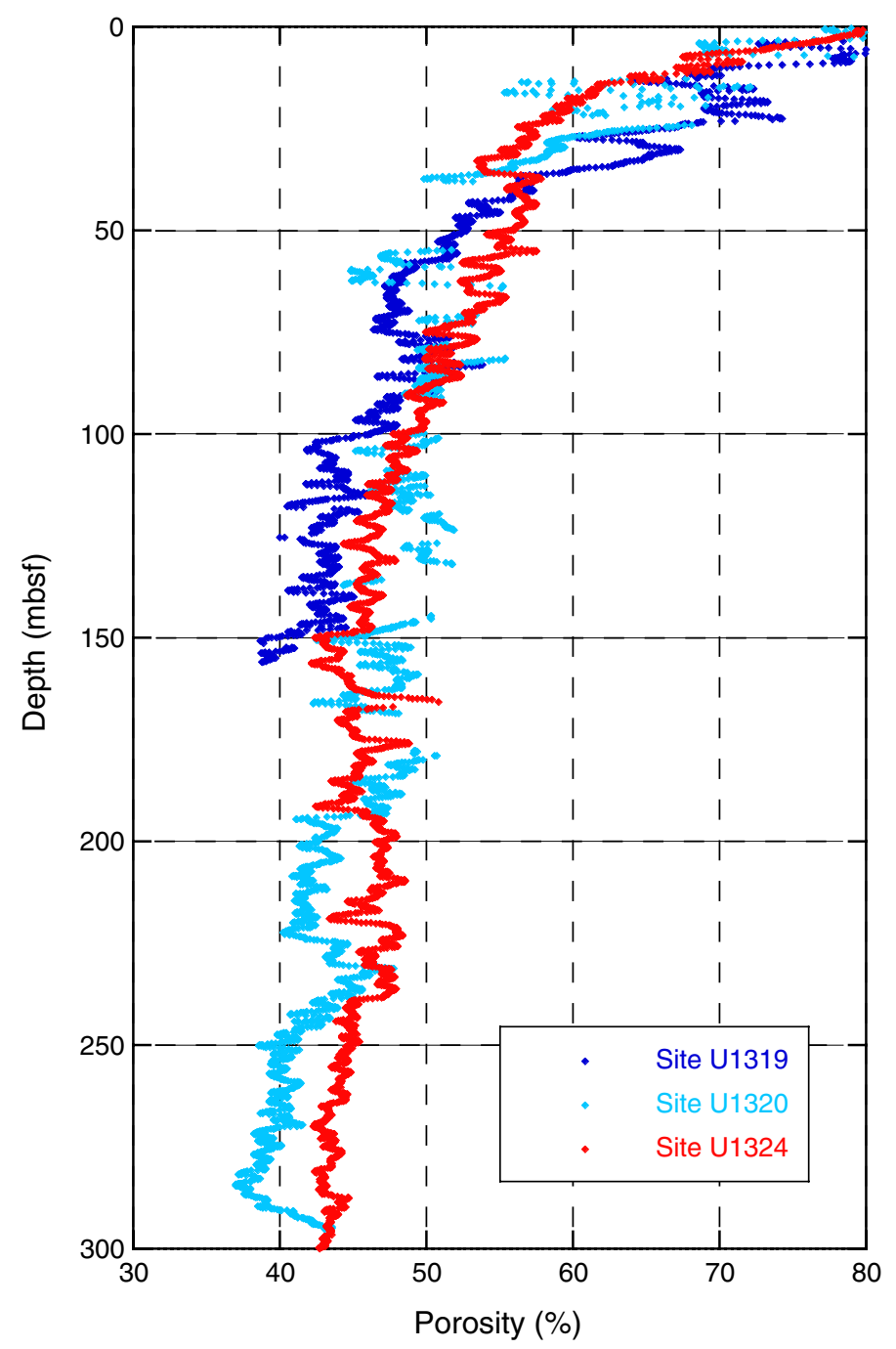


Figure F40. Pore water geochemical profiles at Sites U1319 and U1320 in Brazos-Trinity Basin IV.
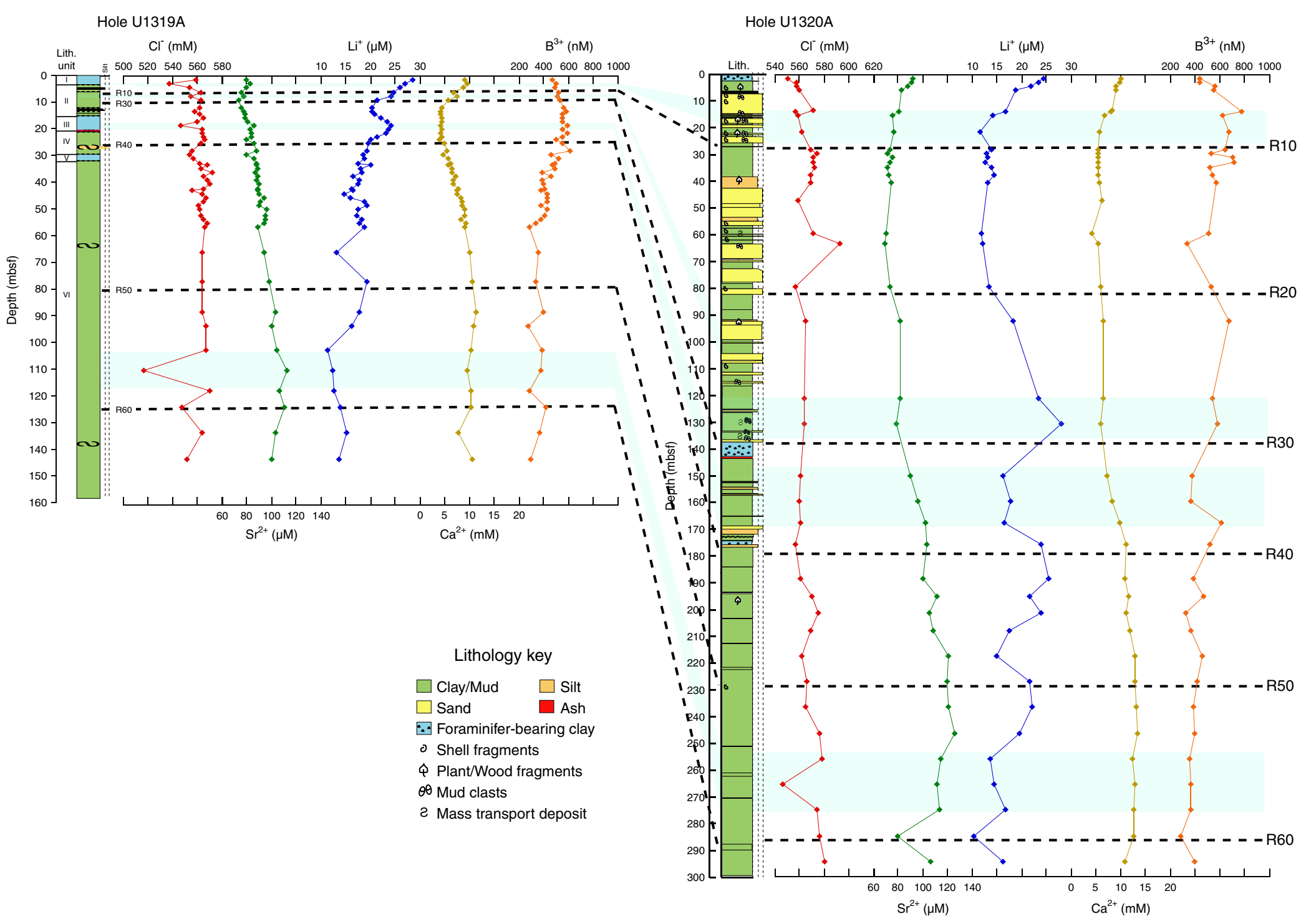

2 Mass transport deposit 


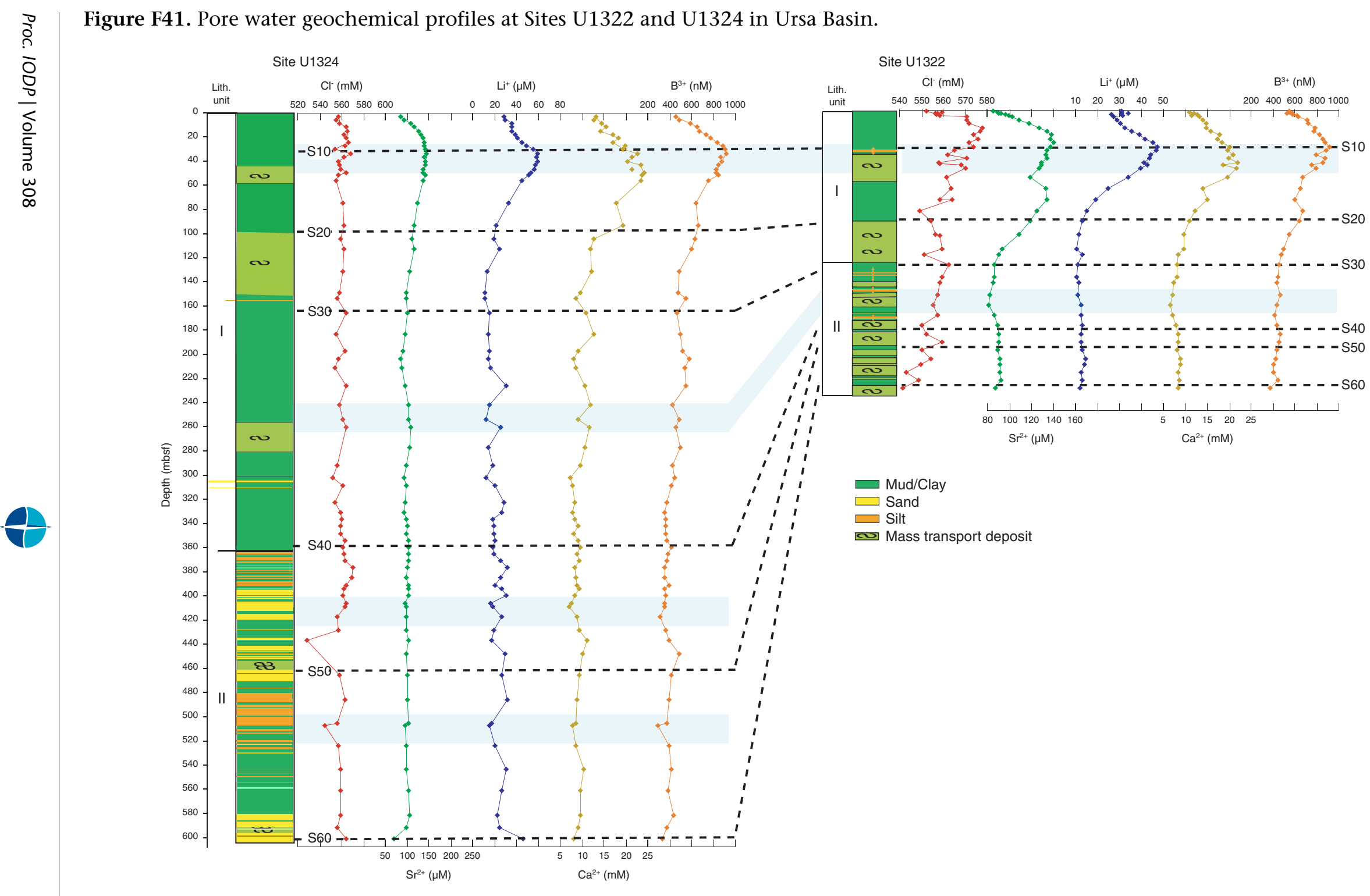


Figure F42. A. Site U1324 porosity vs. depth. B. Site U1322 porosity vs. depth. The change in porosity relative to depth is extremely similar at these two locations. MAD = moisture and density, LWD = logging-while-drilling.

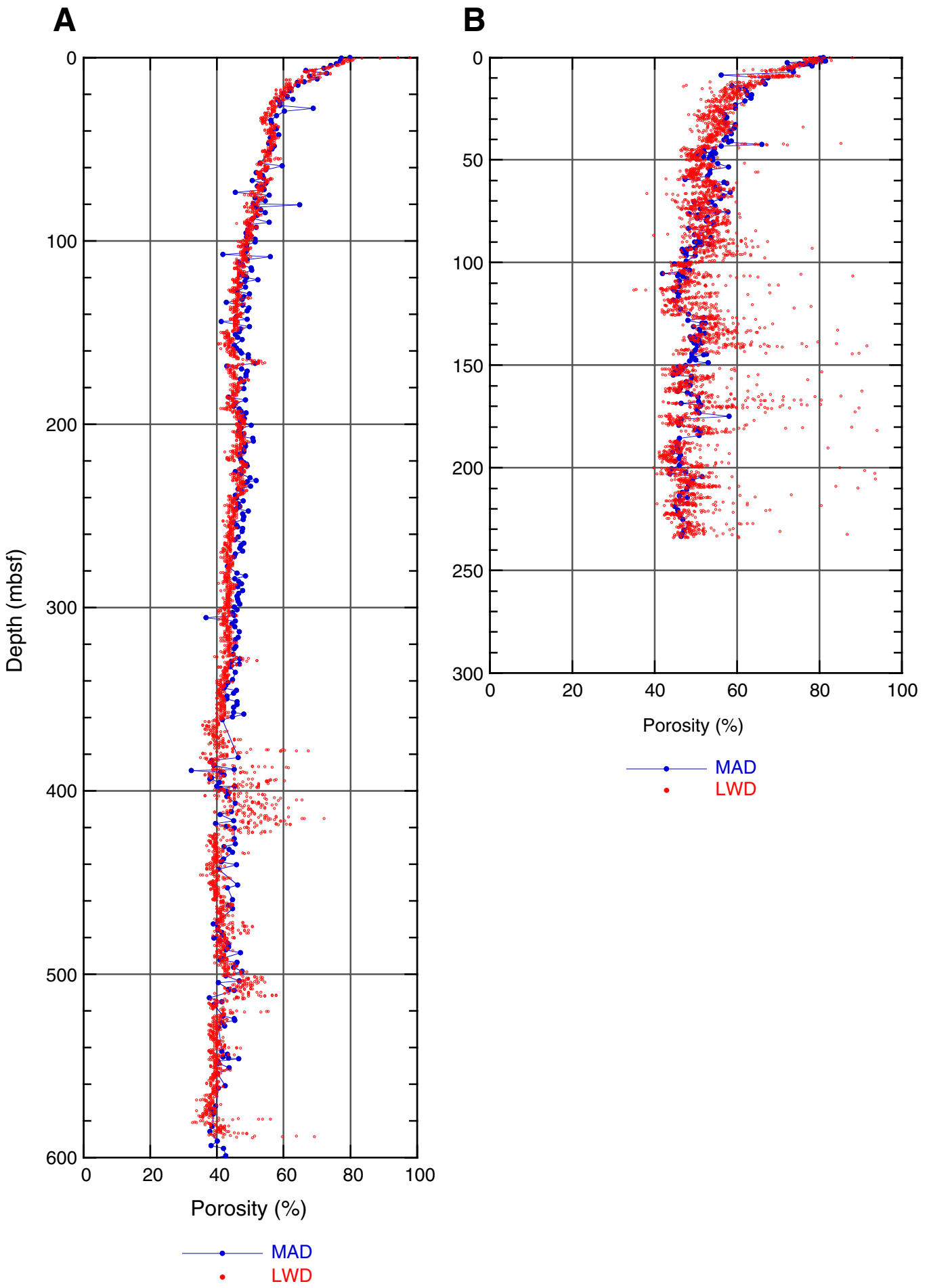


Figure F43. Porosity-based pressure prediction for (A) Site U1322 and (B) Site U1324. Both locations have fundamentally similar results. Conditions are predicted to be more or less hydrostatic to $150 \mathrm{mbsf}$ and at deeper levels pressure rises to more than half of the distance to the lithostatic pressure. BSF $=$ below seafloor, DVTPP $=$ Davis-Villinger Temperature-Pressure Probe, $\mathrm{T} 2 \mathrm{P}=$ temperature/dual pressure.
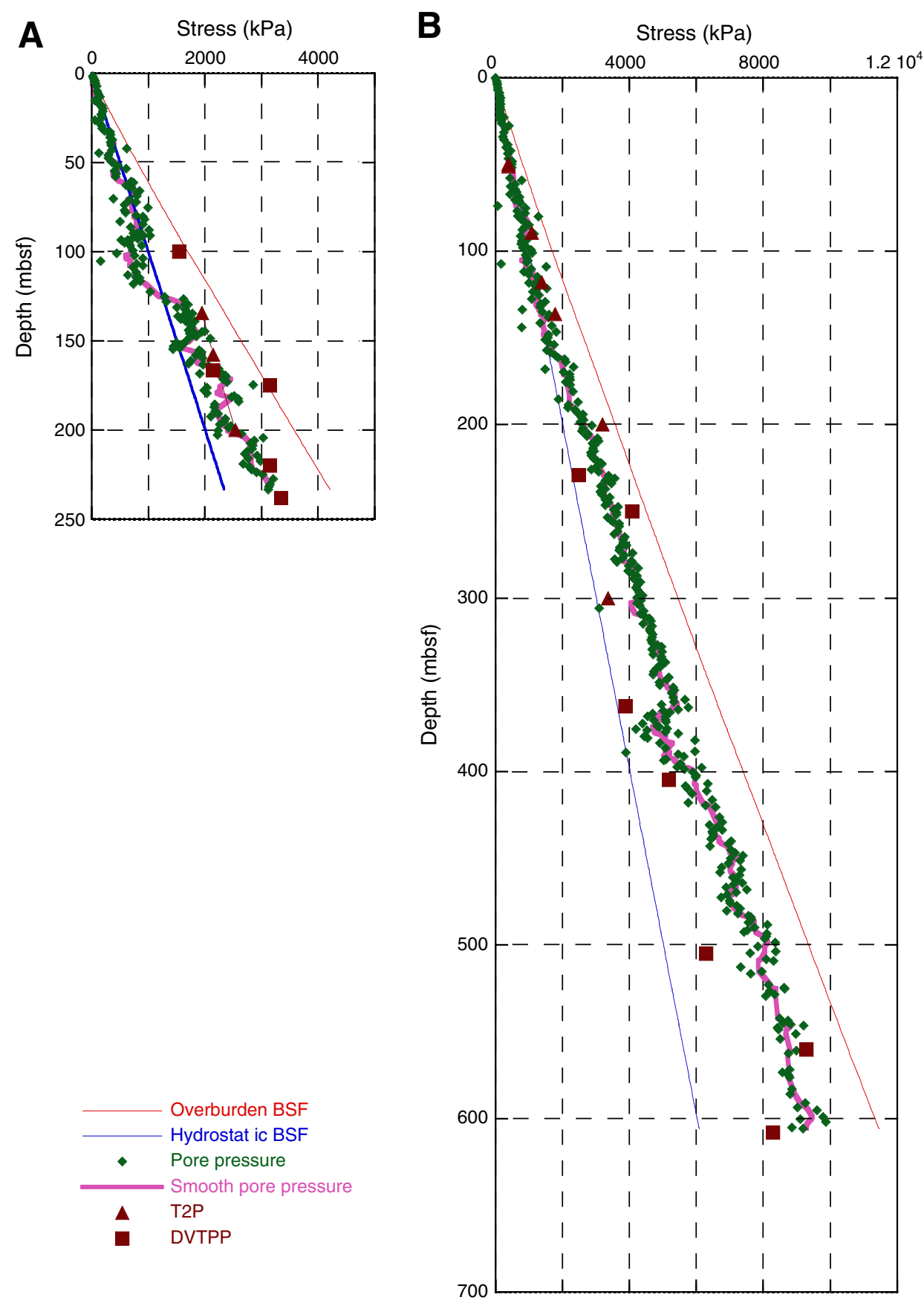
Figure F44. Pressure vs. depth for penetrometer tools (Davis-Villinger Temperature-Pressure Probe [DVTPP] and temperature/dual pressure [T2P] probe). A. Site U1324. B. Site U1322. Pressure data suggest that to a depth of 250 mbsf pore pressures are greater at Site U1322 than at Site U1324. Solid symbols represent penetrations where there was a clear penetration and dissipation, whereas open symbols represent penetrations that were initially subhydrostatic and subsequently recovered to an elevated pressure.
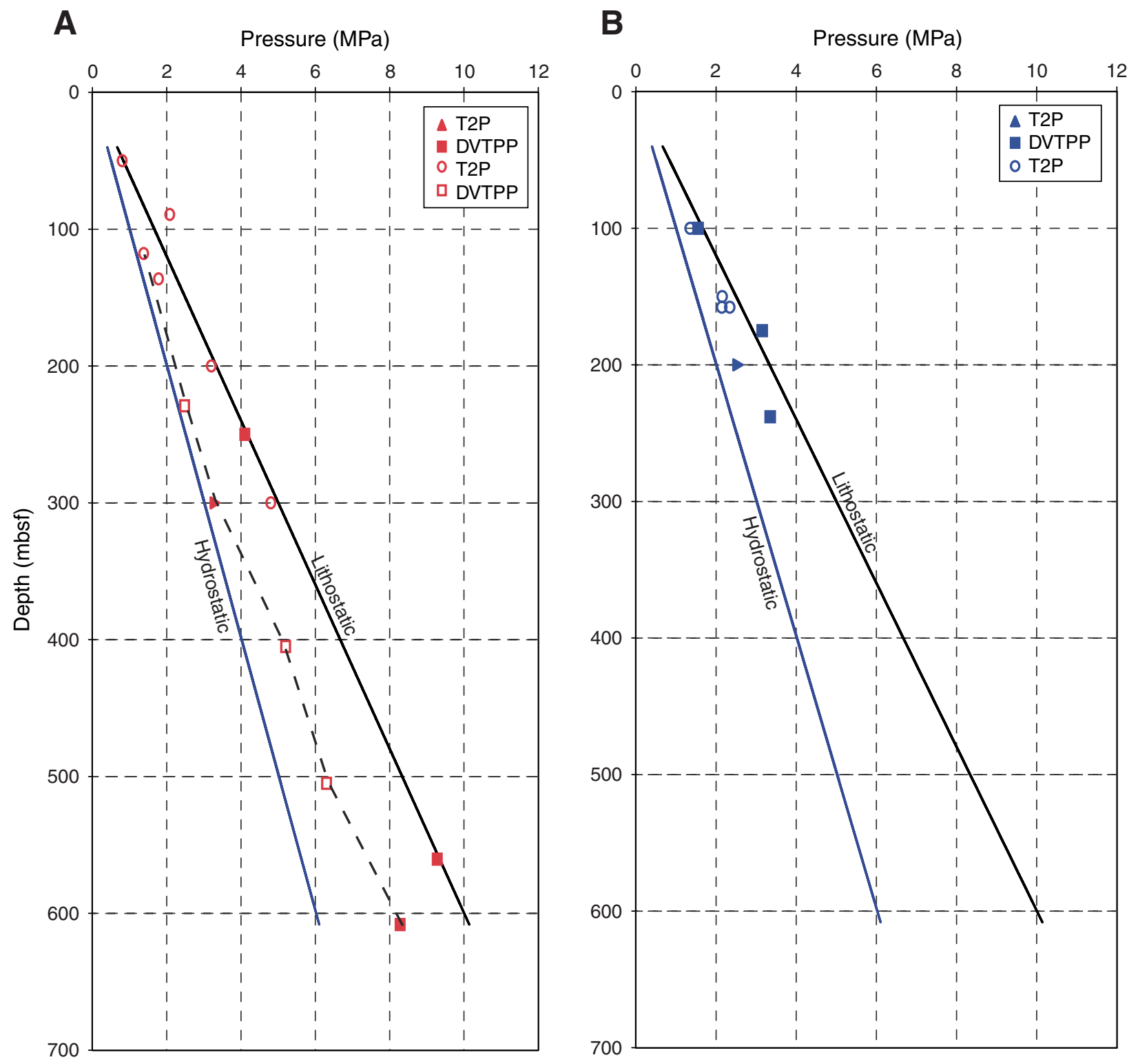
Figure F45. Temperature data for Sites U1322 and U1324. Advanced piston corer temperature (APCT) tool data are corrected to predict the in situ temperature whereas Davis-Villinger Temperature-Pressure Probe (DVTPP) and temperature/dual pressure (T2P) probe data are not corrected. The average gradient at Site U1324 is $18.4^{\circ} \mathrm{C} / \mathrm{km}$, whereas at Site $\mathrm{U} 1322$ the average gradient is $26.2^{\circ} \mathrm{C} / \mathrm{km}$.

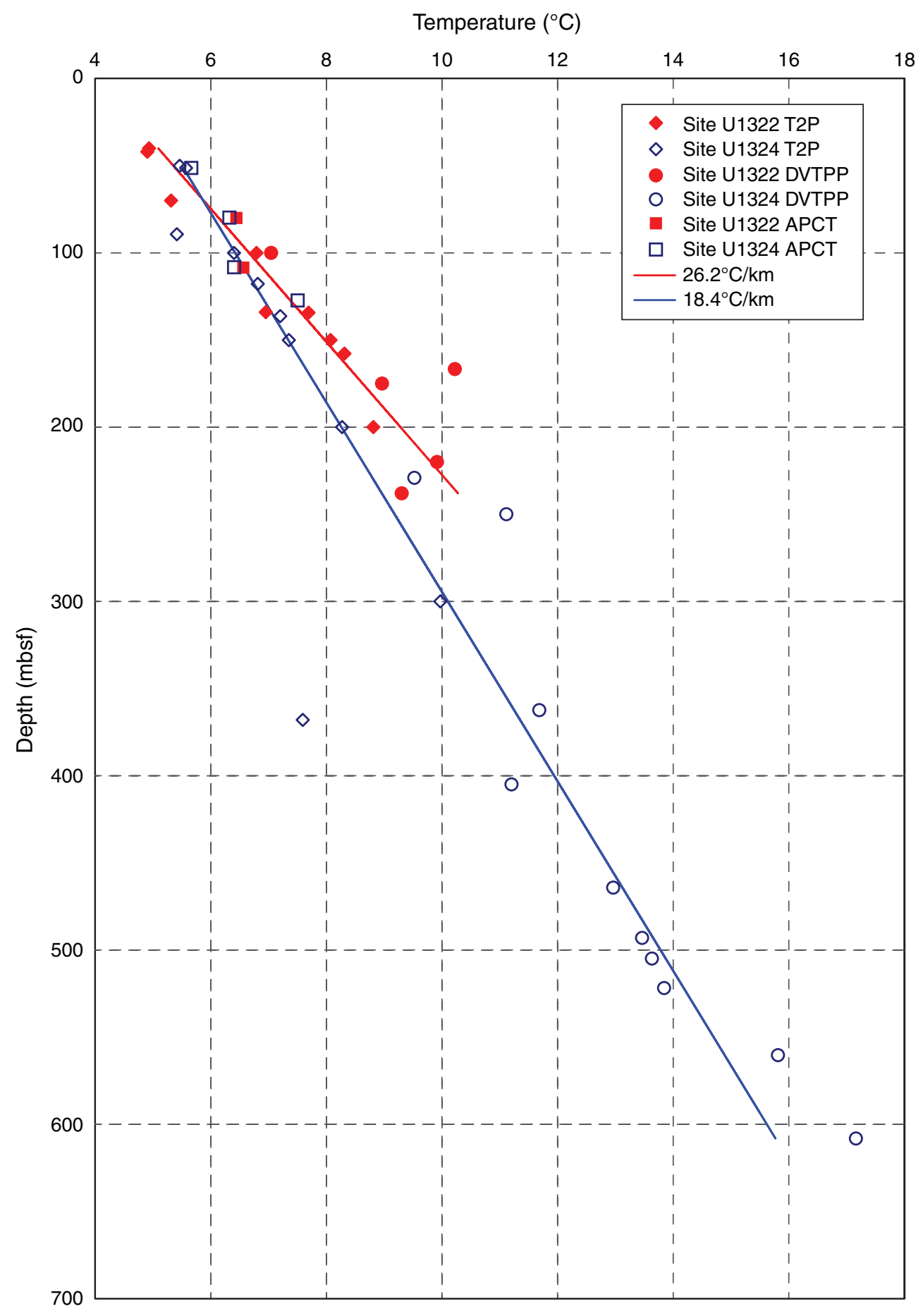


Figure F46. A. Site U1324. Temperature gradient $=\sim 18^{\circ} \mathrm{C} / \mathrm{km}$ (red), overpressure ratio $\left(\lambda^{\star}\right)=\sim 0.6$, overpressure $=$ blue. B. Site U1322. Temperature gradient $=\sim 26^{\circ} \mathrm{C} / \mathrm{km}\left(\right.$ red), overpressure ratio $\left(\lambda^{*}\right)=\sim 0.6$, overpressure $=$ blue. C. Conceptual model of flow in Ursa Basin. The constant overpressure gradient at both sites implies that flow is driven upward at approximately the same rate in both locations within the mudrock above the Blue Unit. However, because Site U1324 is considerably deeper than Site U1322, the pressures at the top of the Blue Unit must be greater at Site U1324 $(\sim 3.1 \mathrm{MPa})$ than at Site U1322 $(\sim 1.3 \mathrm{MPa})$. We infer that the Blue Unit is composed of multiple hydraulically isolated sand bodies. Flow is transported laterally from Site U1324 to U1322 only within the deepest sand body because the overlying sand bodies have been truncated by the Ursa channel-levee system. To the right of the levee, flow is upward through both sands and shales. The elevated temperature gradient at Site U1322 may record the lateral flow within the Blue Unit.

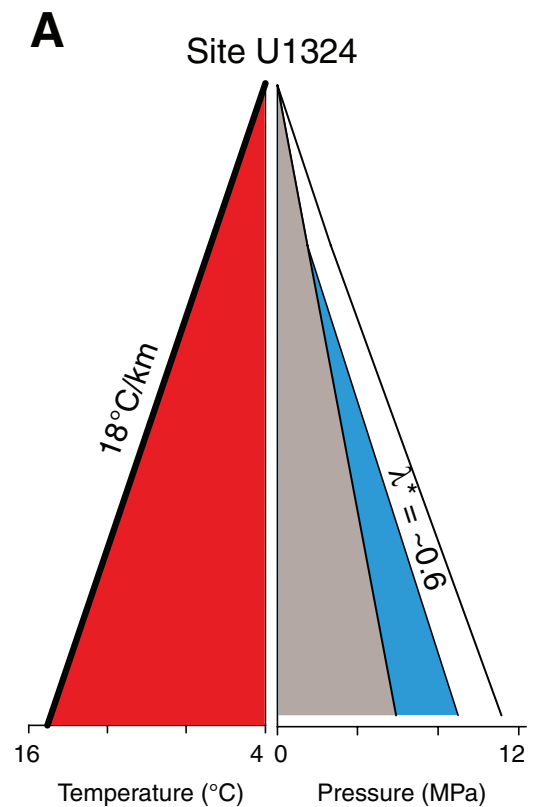

C

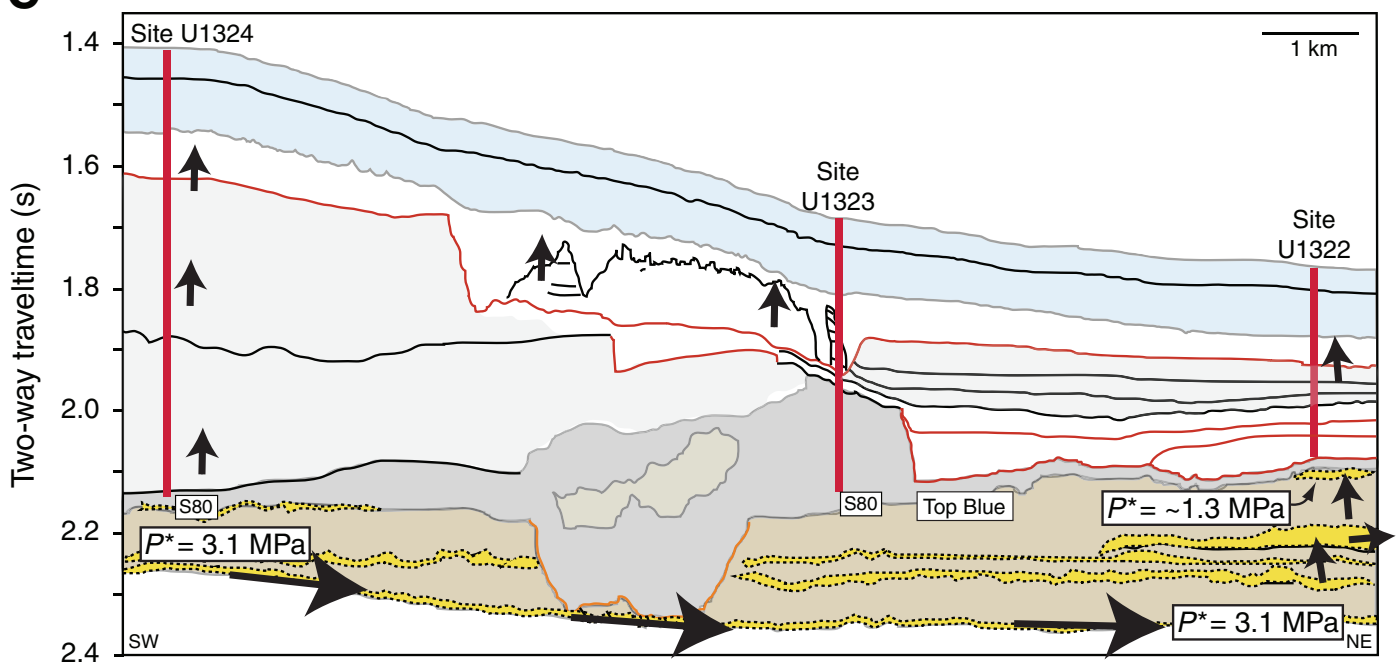

B

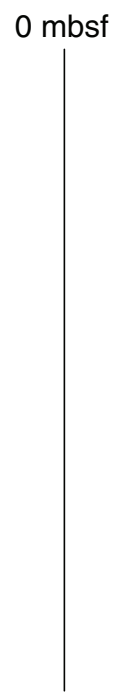

$600 \mathrm{mbsf}$

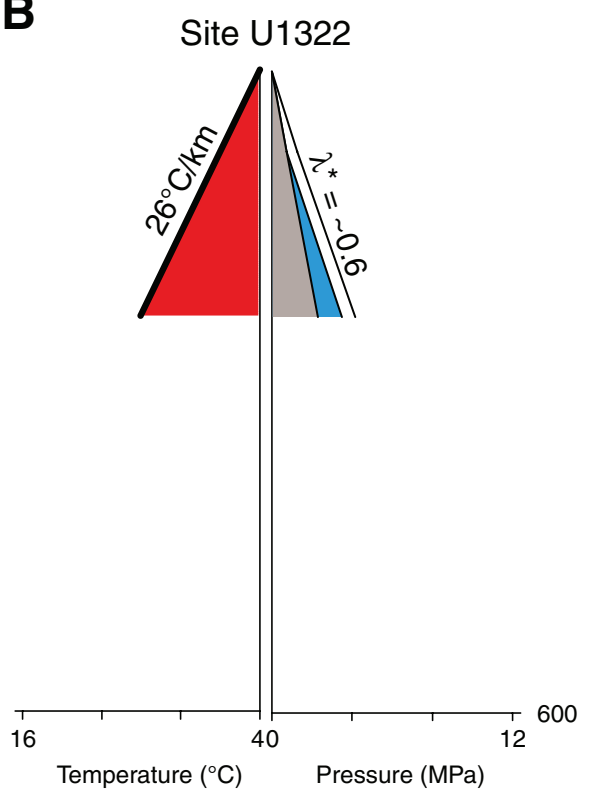


Table T1. Heavy mud used while coring and drilling.

\begin{tabular}{lcccc}
\hline \multicolumn{1}{c}{ Hole } & $\begin{array}{c}\text { Total mud } \\
(\mathrm{bbl})\end{array}$ & $\begin{array}{c}\text { Weight } \\
(\mathrm{ppg})\end{array}$ & $\begin{array}{c}\text { Depth range } \\
(\mathrm{mbsf})\end{array}$ & $\begin{array}{c}\text { Duration } \\
(\mathrm{h})\end{array}$ \\
\hline U1324A (LWD) & 4400 & 10.0 & $477-612$ & $\sim 4.5$ \\
U1324B (coring) & 3880 & 10.5 & $481-608$ & $\sim 36.0$ \\
\hline
\end{tabular}

Note: LWD = logging while drilling.

Table T2. Expedition 308 operations summary.

\begin{tabular}{|c|c|c|c|c|c|c|c|c|c|c|c|c|}
\hline \multirow[b]{2}{*}{ Hole } & \multirow[b]{2}{*}{ Latitude } & \multirow[b]{2}{*}{ Longitude } & \multirow{2}{*}{$\begin{array}{l}\text { Depth } \\
\text { (mbrf) }\end{array}$} & \multirow{2}{*}{$\begin{array}{l}\text { Cores } \\
(N)\end{array}$} & \multirow{2}{*}{$\begin{array}{c}\text { Cored } \\
(\mathrm{m})\end{array}$} & \multicolumn{2}{|c|}{ Recovery } & \multirow{2}{*}{$\begin{array}{c}\text { Drilled } \\
(\mathrm{m})\end{array}$} & \multirow{2}{*}{$\begin{array}{l}\text { Total } \\
\text { penetration } \\
(\mathrm{m})\end{array}$} & \multirow{2}{*}{$\begin{array}{l}\text { Total } \\
\text { depth } \\
\text { (mbrf) }\end{array}$} & \multicolumn{2}{|c|}{ Time on hole } \\
\hline & & & & & & (m) & (\%) & & & & (h) & (days) \\
\hline U1319A & $27^{\circ} 15.9751^{\prime} \mathrm{N}$ & $94^{\circ} 24.1908^{\prime} \mathrm{W}$ & 1440.0 & 18 & 157.5 & 155.29 & 98.6 & 0.0 & 157.5 & 1597.5 & 32.25 & 1.3 \\
\hline \multirow[t]{2}{*}{ U1319B } & $27^{\circ} 15.9857^{\prime} \mathrm{N}$ & $94^{\circ} 24.1908^{\prime} \mathrm{W}$ & 1441.0 & 0 & 0.0 & 0.00 & 0.0 & 180.0 & 180.0 & 1621.0 & 14.17 & 0.6 \\
\hline & \multicolumn{3}{|c|}{ Site U1319 totals: } & 18 & 157.5 & 155.29 & 98.6 & 180.0 & 337.5 & NA & 46.42 & 1.9 \\
\hline U1320A & $27^{\circ} 18.0809^{\prime} \mathrm{N}$ & $94^{\circ} 23.2527^{\prime} \mathrm{W}$ & 1480.4 & 33 & 299.6 & 250.89 & 83.7 & 0.0 & 299.6 & 1780.0 & 70.08 & 2.9 \\
\hline \multirow[t]{2}{*}{ U1320B } & $27^{\circ} 18.0900^{\prime} \mathrm{N}$ & $94^{\circ} 23.2514^{\prime} \mathrm{W}$ & 1479.0 & 0 & 0.0 & 0.00 & 0.0 & 320.0 & 320.0 & 1799.0 & 31.75 & 1.3 \\
\hline & & \multicolumn{2}{|c|}{ Site U1320 totals: } & 33 & 299.6 & 250.89 & 83.7 & 320.0 & 619.6 & NA & 101.83 & 4.2 \\
\hline \multirow[t]{2}{*}{ U1321A } & $27^{\circ} 16.5398^{\prime} \mathrm{N}$ & $94^{\circ} 23.9370^{\prime} \mathrm{W}$ & 1462.0 & 0 & 0.0 & 0.00 & 0.0 & 140.0 & 140.0 & 1602.0 & 10.95 & 0.5 \\
\hline & & \multicolumn{2}{|c|}{ Site U1321 totals: } & 0 & 0.0 & 0.00 & 0.0 & 140.0 & 140.0 & NA & 10.95 & 0.5 \\
\hline U1322A & $28^{\circ} 5.9628^{\prime} \mathrm{N}$ & $89^{\circ} 1.5120^{\prime} \mathrm{W}$ & 1330.0 & 0 & 0.0 & 0.00 & 0.0 & 238.0 & 238.0 & 1568.0 & 21.75 & 0.9 \\
\hline U1322B & $28^{\circ} 5.9642^{\prime} \mathrm{N}$ & $89^{\circ} 1.4995^{\prime} \mathrm{W}$ & 1330.5 & 29 & 234.5 & 236.79 & 101.0 & 0.0 & 234.5 & 1565.0 & 49.00 & 2.0 \\
\hline U1322C & $28^{\circ} 5.9640^{\prime} \mathrm{N}$ & $89^{\circ} 1.5228^{\prime} \mathrm{W}$ & 1330.0 & 1 & 4.5 & 4.53 & 100.7 & 231.5 & 236.0 & 1566.0 & 32.23 & 1.3 \\
\hline \multirow[t]{2}{*}{ U1322D } & $28^{\circ} 5.9753^{\prime} \mathrm{N}$ & $89^{\circ} 1.5104^{\prime} \mathrm{W}$ & 1330.0 & 3 & 26.8 & 27.21 & 101.5 & 148.2 & 175.0 & 1505.0 & 30.10 & 1.3 \\
\hline & & \multicolumn{2}{|c|}{ Site U1322 totals: } & 33 & 265.8 & 268.53 & 101.0 & 617.7 & 883.5 & NA & 133.08 & 5.5 \\
\hline \multirow[t]{2}{*}{ U1323A } & $28^{\circ} 5.4725^{\prime} \mathrm{N}$ & $89^{\circ} 4.3509^{\prime} \mathrm{W}$ & 1271.0 & 0 & 0.0 & 0.00 & 0.0 & 247.0 & 247.0 & 1518.0 & 35.50 & 1.5 \\
\hline & & \multicolumn{2}{|c|}{ Site U1323 totals: } & 0 & 0.0 & 0.00 & 0.0 & 247.0 & 247.0 & NA & 35.50 & 1.5 \\
\hline U1324A & $28^{\circ} 4.7856^{\prime} \mathrm{N}$ & $89^{\circ} 8.3574^{\prime} \mathrm{W}$ & 1066.0 & 0 & 0.0 & 0.00 & 0.0 & 612.0 & 612.0 & 1678.0 & 83.58 & 3.5 \\
\hline U1324B & $28^{\circ} 4.7845^{\prime} \mathrm{N}$ & $89^{\circ} 8.3442^{\prime} \mathrm{W}$ & 1067.5 & 74 & 608.2 & 569.92 & 93.7 & 0.0 & 608.2 & 1675.7 & 122.17 & 5.1 \\
\hline \multirow[t]{3}{*}{ U1324C } & $28^{\circ} 4.7832^{\prime} \mathrm{N}$ & $89^{\circ} 8.3683^{\prime} \mathrm{W}$ & 1066.5 & 8 & 55.1 & 55.70 & 100.9 & 0.0 & 511.8 & 1578.3 & 50.25 & 2.1 \\
\hline & & \multicolumn{2}{|c|}{ Site U1324 totals: } & 82 & 663.3 & 625.62 & 94.3 & 612.0 & 1732.0 & NA & 256.00 & 10.7 \\
\hline & & \multicolumn{2}{|c|}{ Expedition 308 totals: } & 166 & 1386.2 & 1300.33 & 93.8 & 2116.7 & 3959.6 & NA & 583.78 & 24.3 \\
\hline
\end{tabular}

Notes: $N=$ number. $N A=$ not applicable. 